\title{
UNIVERSITATIS OULUENSIS
}

Pekka Mertala

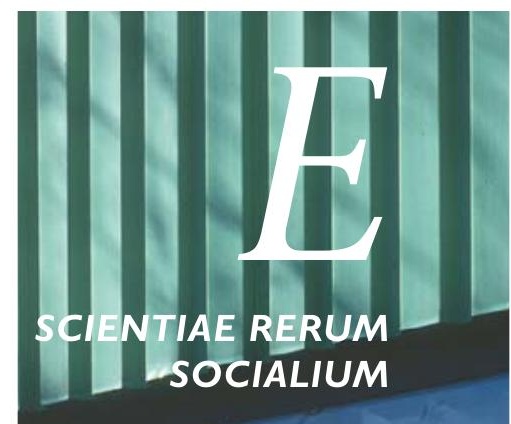

\section{TWO WORLDS COLLIDE?}

MAPPING THE THIRD SPACE OF ICT INTEGRATION IN EARLY CHILDHOOD EDUCATION

UNIVERSITY OF OULU GRADUATE SCHOOL; 



\section{TWO WORLDS COLLIDE?}

Mapping the third space of ICT integration in early childhood education

Academic dissertation to be presented with the assent of the Doctoral Training Committee of Human Sciences of the University of Oulu for public defence in Kaljusensali (KTKI I2), Linnanmaa, on 27 April 2018, at 12 noon 
Copyright (C) 2018

Acta Univ. Oul. E I78, 2018

Supervised by

Professor Eila Estola

Professor Lasse Lipponen

Reviewed by

Professor Johanna Einarsdóttir

Professor Jackie Marsh

Opponent

Professor Kristiina Kumpulainen

ISBN 978-952-62-1860-I (Paperback)

ISBN 978-952-62-I86I-8 (PDF)

ISSN 0355-323X (Printed)

ISSN I796-2242 (Online)

Cover Design

Raimo Ahonen

JUVENES PRINT

TAMPERE 2018 


\title{
Mertala, Pekka, Two worlds collide? Mapping the third space of ICT integration in early childhood education
}

University of Oulu Graduate School; University of Oulu, Faculty of Education

Acta Univ. Oul. E 178, 2018

University of Oulu, P.O. Box 8000, FI-90014 University of Oulu, Finland

\begin{abstract}
The current stage of early years information and communication technology (ICT) integration research has been criticized for not paying enough attention to the unique pedagogical features of early childhood education. Similarly, children's views about educational use of ICT have been underrepresented in research. This dissertation study contributes to resolving these gaps in the literature by exploring children's ideas and preservice teachers' beliefs regarding the role of ICT in early childhood education.

The study consists of two data sets that are reported in three empirical articles. The first study focused on children's ideas and their contextual roots. The second study explored preservice teachers' beliefs about children and ICT at home. The third study investigated preservice teachers' perceptions of ICT integration through the frames of teaching, education, and care, referred to as the EDUCARE approach. In this compilation, the findings of the empirical studies are scrutinized through the analytical device of third space theory.

The findings suggest that there is a dissonance between the meanings children and preservice teachers give to ICT use. Children conceptualized ICT use as a leisure activity whereas preservice teachers approached ICT mainly through learning. The findings also imply that although EDUCARE has been described as a holistic framework in the context of ICT integration, the framework acts as a disintegrating vehicle: When ICT integration was approached from the perspective of teaching, the views were mainly positive. When the perspective was changed to care, the views were profoundly negative. Care-related concerns were associated with preservice teachers' beliefs about children's use of ICT at home being extensive and unregulated. Another exaggerated belief was considering children born-competent ICT users.

The results of this study have several implications for early childhood education, as well as preservice teacher education. To make ICT pedagogy truly meaningful for children, ICT should be approached as a cultural form, and space should be given for children's views, values, and experiences. Additionally, educational technology courses need to pay more attention to aspects of care, as well as to preservice teachers' often unrealistic beliefs about children and technology.
\end{abstract}

Keywords: early childhood education, teachers' beliefs, technology, third space 



\section{Mertala, Pekka, Kahden maailman kohtauspisteessä? Varhaiskasvatuksen teknologiaintegraation kolmatta tilaa kartoittamassa}

Oulun yliopiston tutkijakoulu; Oulun yliopisto, Kasvatustieteiden tiedekunta

Acta Univ. Oul. E 178, 2018

Oulun yliopisto, PL 8000, 90014 Oulun yliopisto

\section{Tiivistelmä}

Varhaiskasvatuksen kontekstissa tehty teknologiaintegraatiotutkimus ei ole huomioinut riittävästi varhaiskasvatuksen pedagogisia erityispiirteitä. Myös lasten näkemykset ovat jääneet vähälle huomiolle. Tutkimukseni vastaa tähän tarpeeseen selvittämällä lasten ideoita ja lastentarhanopettajaopiskelijoiden uskomuksia tieto- ja viestintäteknologian roolista varhaiskasvatuksessa.

Tutkimusta varten kerättiin kaksi aineistoa ja tulokset on raportoitu kolmessa artikkelissa. Ensimmäinen osatutkimus keskittyi lasten ideoihin ja niiden mediakulttuurisiin juuriin. Toisessa osatutkimuksessa selvitettiin opettajaopiskelijoiden uskomuksia siitä, miten lapset käyttävät tieto- ja viestintäteknologiaa kotona. Kolmannen osatutkimuksen kohteena oli opetuksen, kasvatuksen ja hoidon kehysten (EDUCARE-malli) roolit ja merkitykset opettajaopiskelijoiden teknologiaintegraatiokäsityksissä. Yhteenveto-osiossa tuloksia tarkastellaan kolmannen tilan teorian kautta.

Tutkimuksen tulokset osoittavat, että lasten ja opettajaopiskelijoiden tieto- ja viestintäteknologialle antavat merkitykset eroavat toisistaan. Lapset suhtautuvat tieto- ja viestintäteknologian käyttöön viihteenä, mutta opettajaopiskelijat käsitteellistävät sen oppimisen ja opettamisen välineenä. Tulokset osoittavat myös, että vaikka EDUCARE-malli kuvataan eheyttävänä viitekehyksenä, teknologiaintegraation tapauksessa sillä on myös hajottava ulottuvuus. Kun teknologiaintegraatiota tarkasteltiin opetuskehyksen kautta, näkemykset olivat myönteisiä. Kun näkökulma vaihtui hoitopainotteiseksi, näkemykset muuttuivat huomattavan kielteisiksi. Hoitokehyksen kautta tuotetut huolet kumpusivat uskomuksista, että lapset käyttävät liikaa tieto- ja viestintäteknologiaa kotona. Toinen yleinen uskomus oli, että lapset ovat syntyjään taitavia tieto- ja viestintäteknologian käyttäjiä.

Tutkimuksen tulokset ovat merkityksellisiä sekä varhaiskasvatuksen pedagogiikan että opettajankoulutuksen kannalta. Jotta tieto-ja viestintäteknologiaa hyödyntävä pedagoginen toiminta on lapsille merkityksellistä, tulee tieto- ja viestintäteknologiaa käsitellä (media)kulttuurisena ilmiönä ja toiminnassa tulee olla tilaa lasten näkemyksille ja kokemuksille. Opettajankoulutuksessa tulee kiinnittää huomiota hoitokehyksen huomioimiseen sekä opettajaopiskelijoiden usein epärealistisiin uskomuksiin lapsista ja teknologiasta.

Asiasanat: kolmas tila, tieto- ja viestintäteknologia, uskomukset, varhaiskasvatus 



\section{Acknowledgements}

In April 2013, I was conducting my master degree studies and had enrolled for the "Contemporary Research Discussion" course. The final meeting of the course was a get-together lunch, during which I happened to sit opposite our lecturer. At one point, she asked me whether I knew any preschool teacher who had used digital technologies with children, as she was looking for a researcher for a forthcoming development project. I said that I did know someone suitable-me.

That lecturer was Professor Eila Estola, who later became my principal supervisor. I am deeply grateful to Eila for all the support she has given me during my postgraduate studies. On several occasions, her trust and faith in my work and me has been much greater than my own. I would also like to thank my second supervisor, Professor Lasse Lipponen, whose insightful comments were valuable when compiling the summary part of my thesis. My sincere gratitude goes to Professor Kristiina Kumpulainen for agreeing to act as the official opponent for the public defense of my dissertation. I would also like express thanks to Professor Johanna Einarsdóttir and Professor Jackie Marsh for reviewing my dissertation, and Anna-Maija Puroila and Anu Alanko deserve heartfelt thanks for acting as my follow-up group.

If it takes a village to raise a child, it takes one to raise a researcher as well. I have been privileged to be part of several scholarly and non-scholarly communities. First, I would like to say thanks to the Living Stories research group and the staff of Early Childhood Education degree program. Special appreciation goes to the magnificent MAVAKO collective (where does this name come from?): Jaana Juutinen, Satu Karjalainen, Paula Loukkola, Hennariikka Valppu-Paaso, Virpi Mettiäinen, Virve Keränen, Riikka Kess, and Jaakko Moilanen. Jaakko, alongside Jari Laru, also reviewed the first draft of my dissertation in the pre-examination seminar. Thank you both for your sharp-eyed comments. As my (messy) desk is located in the premises of Learning and Educational Technology research group (LET), I would like to thank my current and former roommates Jaana Isohätälä, Eetu Haataja, and Heikki Kontturi for their companionship. One LET member who deserves special thanks is Arttu Mykkänen, with whom I studied early childhood education and whose practical tips were a great source of help when writing the summary. Special thanks go also to Teemu Hanhela from the Theory and Philosophy of Education research group for being a good friend as well as a source of inspiration in pursuing my academic career (we should have coffee more often, though). Outside of the University of Oulu, I would like to thank Saara Salomaa 
and Lauri Palsa from the Finnish National Audiovisual Institute for being my media education partners in crime. Warm thanks go also to my current and former bandmates from Oiva Väre and Tuulia: Sanna Paitsola, Mervi Tervo, Hannu Hautanen, Samuli Paitsola, Mikko Alanne, Hannu Tiri, and Petteri Lehtola. Unfortunately, obtaining a $\mathrm{PhD}$ has had no positive impact on my time or my singing voice. I would like to thank Hannele Karikoski for engaging me in the wondrous world of early childhood education, and my former colleagues from Mäntylä-Snellman päiväkoti for showing me how the big words used in the university can be turned into pedagogical practices.

This work would not have been possible without funding from the Jenny and Antti Wihuri Foundation, which generously evaluated my research as being worth two full-year grants. I greatly appreciate this support. I would also like to express my gratitude to all the children and preservice teachers who participated in the empirical studies.

The dearest ones are saved for last. First, I would like to thank my parents Eeva-Liisa and Osmo for their endless support and encouragement. Thanks also go to my brothers Jukka and Eetu. As for my fabulous children Iitu and Okko-I have no words to tell you how much I love you. Thus, instead, from now on, I will give you guys an extra kiss and hug every day - that is a promise. Finally, I would like to thank Salla for supporting my quest for an academic career. You have endured my periodical absence of mind, but what is even more important is that, when needed, you have dragged me away from my thoughts by reminding me (more or less subtly) that there are things in life much more important than third spaces and teacher beliefs. 


\section{List of original publications}

This thesis is based on the following publications, which are referred throughout the text by their Roman numerals:

I Mertala, P. (2016). Fun and games: Finnish children's ideas for the use of digital media in preschool. Nordic Journal of Digital Literacy, 11(04), 202-226. https://doi.org/10.18261/issn.1891-943x-2016-04-01

II Mertala, P. (2017). Wonder children and victimizing parents: Preservice early childhood teachers' beliefs about children and technology at home. Early Child Development and Care. Advance online publication. https://doi.org/10.1080/03004430.2017.1324434

III Mertala, P. (2017). Digital technologies in early childhood education: A frame analysis of preservice teachers' perceptions. Early Child Development and Care. Advance online publication. https://doi.org/10.1080/03004430.2017.1372756 


\section{Contents}

Abstract

Tiivistelmä

Acknowledgements

List of original publications $\quad 9$

$\begin{array}{ll}\text { Contents } & 11\end{array}$

1 Introduction $\quad 13$

1.1 The importance of studying preservice teachers and children ............... 15

1.2 Structure of the dissertation ............................................................. 18

2 Theoretical framework $\quad 19$

2.1 Third space theory ................................................................................ 19

2.1.1 The bridging interpretation of the third space .......................... 21

2.1.2 The intersectional interpretation of the third space .................... 22

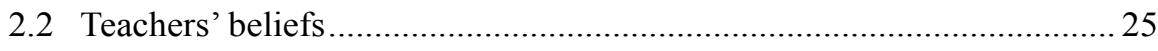

2.2.1 Construction of teachers' beliefs ............................................ 26

2.2.2 Content of teachers' beliefs ................................................... 27

2.3 The third space as a space of beliefs ................................................... 28

2.3.1 Teachers' beliefs about children and ICT at home (the first space) ................................................................................ 29

2.3.2 Teachers' beliefs about the essence of early childhood education (the second space) .................................................. 31

3 Aims of the study and the research question 35

4 Methodological considerations $\quad 37$

4.1 Qualitative research as a research methodology ................................. 37

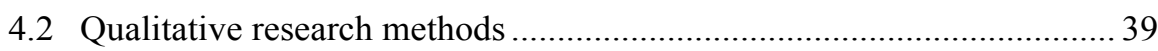

4.3 Locating the study on the qualitative continuum ................................. 40

5 Methods used in the study $\quad \mathbf{4 3}$

5.1 Participants, context, and the research design.................................... 43

5.1.1 Using drawings to explore children's ideas ............................... 44

5.1.2 Using written assignments to explore preservice teachers' beliefs ....................................................................... 46

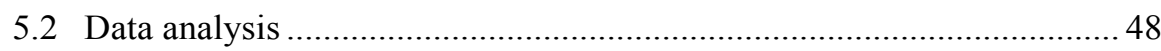

5.2.1 Analysis of drawings: Monotype mixed analysis ...................... 48

5.2.2 Analysis of the written assignments: Constant comparative analysis ............................................................. 49

6 Overview of the articles 53 
6.1 Article I: Fun and games: Finnish children's ideas for the use of digital media in preschool

6.2 Article II: Wonder children and victimizing parents: Preservice early childhood teachers' beliefs about children and technology at home

6.3 Article III: Digital technologies in early childhood education: A frame analysis of preservice teachers' perceptions 54

7 Results: Mapping the third space of ICT integration in early childhood education 57

7.1 First and second spaces in children's ideas 57

7.1.1 "One could play Mario and listen to good music, like Robin" 60

7.1.2 "It' $d$ be fun to practice reading with a computer" 61

7.2 First and second spaces in preservice teachers' beliefs 62

7.2.1 "We have to be aware of the world they are living in" .63

7.2.2 "My feelings about using ICT are still a bit conflicted" 65

7.3 Discussion of the results 69

7.3.1 Dissonance between the meanings children and teachers give to ICT use shaping the third space .70

7.3.2 Teachers' unrealistic beliefs about children and ICT shaping the third space .71

7.3.3 The multifaceted nature of early childhood education shapes the third space ............................................................ 73

8 Conclusions $\quad \mathbf{7 5}$

8.1 Evaluation of the research .......................................................... 75

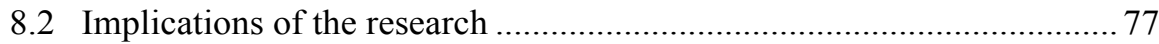

8.2.1 Implications for future research............................................. 77

8.2.2 Implications for pedagogical practices of early childhood

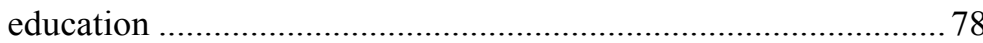

8.2.3 Implications for teacher education.......................................... 80

$\begin{array}{lr}\text { References } & 83\end{array}$

$\begin{array}{lc}\text { Original publications } & 103\end{array}$ 


\section{Introduction}

Currently, all institutional education fields are expected to integrate information and communication technology ${ }^{1}$ (ICT) in their curricula and pedagogical practices. This is also the case in early childhood education ${ }^{2}$, and ICT has gradually found its way into early years' curricula in several countries (e.g., Bølgan, 2012; Edwards, 2013). Finland is not an exception. The new Finnish National Core Curriculum Guidelines for Early Childhood Education (Opetushallitus, 2016) and Pre-Primary Education (Opetushallitus, 2014) are the first normative curricular documents to demand that children's ICT competence needs be supported in early childhood education. The National Core Curriculum Guidelines for Early Childhood Education guide the education of children under five years old, whereas the National Core Curriculum Guidelines for Pre-Primary Education guide the education of six-year-old children during the final year before they enter primary education. Attendance in early childhood education is optional, and 53\% of twoyear-olds, $68 \%$ of three-year-olds, $74 \%$ of four-year-olds, and $79 \%$ of five-yearolds attend (OECD, 2017). Participation in pre-primary education has been mandatory since 2015 (Perusopetuslaki 1998, 2014).

The former curricula merely stated that educators should be aware of the new opportunities offered by technological development and take into account the benefits and opportunities of ICT in their work (Sosiaali- ja terveysalan tutkimusja kehittämiskeskus, 2005, p. 14), and that the affordances of the learning environment should support children's growth to become members of a modern information society (Opetushallitus, 2010, p. 11). The contrast with the new curricula is stark. In both curricula, ICT competence is included in transversal competences which refer to the entity consisting of knowledge, skills, values, attitudes, and will, as well as the ability to apply the knowledge and skills as required in a given situation (Opetushallitus, 2014, 2016). More precisely, ICT competence is named as an important civic skill required in the everyday lives of

\footnotetext{
${ }^{1}$ It has been argued that new digital media can no longer be regarded simply as a matter of "information" or of "technology" (Buckingham, 2015). The decision to use the term ICT is made on the contextual basis of it being the term used in Finnish early childhood education curricula (Opetushallitus, 2014, 2016). In this study, ICT is understood in an inclusive manner to reflect the broad range of devices and software to be experienced by children across home and preschool (Plowman, 2016). The terms "information and communication technology," "digital technology," "technology," and "digital media" are used here as synonyms.

${ }^{2}$ The term follows Finnish discourse and refers to institutional education for children from 0 to 6 years old before primary school. The term preschool is used when discussing the premises where early childhood education is provided.
} 
children and families, interactions between people, and participation in society. The instruction includes familiarization with different ICT devices, services, and games and that ICT is used to support children's interactional skills, learning skills, and the gradual development of writing and reading skills (Opetushallitus, 2014, 2016).

The core argument behind the promotion of educational ICT integration is that without it, early childhood education fails to meet children's changing educational needs which are, to a notable extent, caused by the digitalization of society ${ }^{3}$. This perspective is well captured in Patrik Hernwall's (2016, p. 7) statement that "the changed conditions for children in their life-world calls for a change in the 'professional content' of the preschool, if the preschool is to be a contemporary professional practice of relevance" (see also e.g., Dunn, Grey, Moffett, \& Mitchell, 2016; Koivula \& Mustola, 2017; Lafton, 2012). Early childhood education providers have begun to dispel the digital divide between children's informal and formal learning environments. For example, the increase in the purchase and use of touch-screen devices (Blackwell, Wartella, Lauricella, \& Robb, 2015) has been justified with the argument that they are the type of ICT children use at home (Brown \& Englehardt, 2017; Dong \& Newman, 2016; Roberts-Holmes, 2014).

In my interpretation, these "assimilative" viewpoints signal professional uncertainty regarding the role of ICT in early childhood education and the teacher's role as an ICT pedagogue. This notion is supported by Susan Edwards, Michael Henderson, Donna Gronn, Anne Scott, and Moska Mirkhil (2017) who have pointed out that the arguments which suggest that ICT use in early childhood education should be the same as that found at home divert our attention from understanding the nature of the setting and thus, understanding the role of technology in education and the home. They emphasized that because home and preschool are different settings the ICT cultures in these two settings are different: Whereas home ICT use is mostly about leisure, ICT use in preschool is more about learning. ${ }^{4}$ Although $\mathrm{I}^{5}$ agree with Edwards and her colleagues about the importance

\footnotetext{
${ }^{3}$ Such discourses are not restricted to early childhood education but also exist in the fields of primary education (e.g., Kupiainen, 2013; Palmgren-Neuvonen, Jaakkola, \& Korkeamäki, 2016).

${ }^{4}$ In addition, preschool teachers have expressed that the role of ICT should be different in early childhood education than at home. In these cases, the teachers suggest that due to children's (presumed) high ICT use at home, preschool should be a place free of technology use (e.g., Friedrichs-Liesenkötter, 2015; Palaiologou, 2016b).

${ }^{5}$ In this dissertation, "I" am a former preschool teacher born in 1982. During the data collection period, I worked as a project researcher and teacher in the Faculty of Education of University of Oulu. My interest in third space theory and children's and teachers' views about ICT use stemmed from my experiences as a preschool teacher. Back then, I noticed how many children found it motivational to write their own stories with a computer and that these stories often contained references from the
} 
of building early years ICT pedagogy into the broader pedagogical objectives of early childhood education (Mertala, 2017; Salomaa \& Mertala, in press), merely acknowledging that home and preschool are two different cultural spaces which operate according to their own rules is also an insufficient starting point. As the widespread ICT integration in early childhood education is a new phenomenon, home is where young children's first encounters with ICT take place (Chaudron et al., 2015; Palaiologou, 2016a; Suoninen, 2014). This means that children have ICTrelated experiences, knowledge, skills, views, values, and attitudes, and they do not gravitate toward ICT use in preschool from a tabula rasa position. In addition, the experiences children have shape the way they engage in ICT-mediated practices in early childhood education. In addition, teachers have beliefs about children's experiences with ICT at home (e.g., Dong \& Newman, 2016; Ihmeideh \& Alkhawaldeh, 2017; Lehtikangas \& Mulari, 2016), as well as beliefs about the essence of early childhood education (e.g., Einarsdóttir, 2003; Niikko \& Ugaste, 2012; Sheridan, Williams, Sandberg, \& Vuorinen, 2011). These beliefs affect the teachers' pedagogical decisions regarding ICT use.

In this dissertation, I move beyond the discourses of assimilation and differentiation by applying a framework which acknowledges both — children's informal ICT experiences and the unique pedagogical nature of early childhood education. More precisely, I explore the field of early years ICT integration is explored through the lenses of preservice teachers ${ }^{6}$ and children via analytical device of third space theory (e.g., Bhabha, 1994; Potter \& McDougall, 2017).

\subsection{The importance of studying preservice teachers and children}

So far, the vast body of teacher research in early years ICT integration has focused on in-service teachers ${ }^{7}$. One consistent theme in in-service teacher research is teachers' reserved attitudes toward implementing digital technologies in early childhood education practices (e.g., Hernwall 2016; Palaiologou 2016b). It is often

\footnotetext{
children's lifeworld outside preschool (i.e., references to media culture, family, and home). For further discussion see Mertala (2015a).

${ }^{6}$ Preservice teacher refers here to teacher candidates who are going through their initial training. As in the literature review, I use the term "teacher" when I discuss the literature and findings that apply to pre-service and in-service teachers. I use the terms "preservice teacher" and "in-service teacher" when I describe these particular groups.

${ }^{7}$ Only 10 of the 31 reviewed articles had preservice teachers as participants. Furthermore, four articles were derived from the same two data sets which means that a total of eight studies were published between 2010 and 2017
} 
assumed that younger "digital native preservice teachers," in turn, are free of such hesitation, as they view "computers as just another part of their world and everyday life" (Zaranis, Oikonomidis, \& Linardakis, 2016, p. 204; see also, Lei 2009; Szeto Cheng, \& Hong, 2016), and therefore, their attitudes toward using ICT with children can be assumed to be more positive. According to Mark Prensky's (2001, p. 2) original definition, digital natives - born in the early 1980s and after-are surrounded by and using computers, videogames, digital music players, video cams, cell phones, and all the other toys and tools of the digital age and thus, are native speakers of the digital language of computers, video games, and the internet. In Prensky's (2001, p. 3) view, the older generations - including older in-service teachers - are "digital immigrants" who, despite their efforts to adapt to the new digital environment, always retain, to some degree, their "accent," that is, their foot in the past because today's older folk were "socialized" differently from their children and are now in the process of learning a new language. ${ }^{8}$

It is true that unlike their older in-service colleagues, digital technologies, including personal computers and mobile phones, have been part of preservice teachers' lives since their own childhood. However, it appears that the claims about preservice teachers having a notable positive attitude toward using ICT in early childhood education are based on a simplistic view of who preservice teachers are. In such claims, (young) preservice teachers are treated as members of a (fictitious) homogenous generation and are not recognized as teachers in training, who interpret and evaluate things from the perspective of a (future) educational professional. Such claims pay no attention to the fact that preservice teachers also have deeply held beliefs about teacherhood, children, and the essence of early childhood education (e.g., Isikoglu, 2008; Richardson, 2003; Stockall \& Davis, 2011).

In the Finnish context, early childhood teachers require a bachelor's degree. Eligibility can be obtained via two different routes: by studying early childhood education at university or by studying social sciences and specializing in early childhood education at a university of applied sciences. Only a university degree qualifies one to teach in pre-primary education. According to a recent study by the Finnish National Audiovisual Institute, $66.7 \%$ of Finnish university-based early childhood teacher students felt there was a lack of media education contentincluding ICT pedagogy-in their training (Salomaa, Palsa, \& Malinen, 2017).

\footnotetext{
${ }^{8}$ For critical perspectives on digital native discourse, see e.g. Paul Kirschner and Pedro De Bruyckere (2017).
} 
Like the preservice teachers, young children are also considered digital natives (Roberts-Holmes, 2014; Zevenbergen, 2007). In addition, children's own ideas about and perceptions of ICT use in early childhood education have seldom been a topic of scientific interest (Selwyn, Boraschi, \& Özkula, 2009). As children are the ultimate "end users" of ICT in the classroom, more attention must be paid to their understanding and life-worlds (Buckingham, 2015; Selwyn et al., 2009). The shortage of child-centered research is also contradictory to the contemporary view of childhood, where children are understood as knowledgeable and competent agents, whose views and ideas need to be taken into consideration in the planning of policies and services (e.g., Alasuutari, Karila, Alila, \& Eskelinen, 2014; Corsaro, 2005; Einarsdóttir, 2007). More common are designs where children's ICT use is observed without asking specific questions of the children (e.g., Flewitt, Messer, \& Kucirkova, 2015; Petersen, 2015). In addition, studies that used child interviews focused on children's reports of what children do with ICT but include no evaluation of the practices (e.g., Aubrey \& Dahl, 2014; McKenney \& Voogt, 2010, cf. Dunn et al., in press; Morgan, 2010). However, when evaluations are asked for, they are often treated in a somewhat superficial manner: Jill Dunn and her colleagues. (2016) noted that young primary school students considered the use of tablet computers at school to be fun. As a conclusion, Dunn et al. (2016) stated that "the children in this study particularly enjoyed the playful element of learning," and thus "the children's voices in this study validate the playful possibilities in using tablets in learning" (2016, p. 9) In my view, the authors do not dig deep enough into the question what does it mean that children consider using tablets "fun"? "Fun" is a highly subjective and situated concept: To give an example, one child in Dunn et al. (2016) study commented that using tablets is "more funner than doing work" and that he "hate it when you have to do hard stuff while you are waiting to do all the fun stuff" (2016, p. 7). Here, the child uses the concept of "fun" to compare different activities of which some are more fun than others. His dislike of "work" and "hard stuff" can refer to the child's lack of perseverance or that the non-tablet-based activities in his class are not child-initiated or playful. In addition, children's and adults' views about the playfulness of activities can be very different. For instance, Alex Morgan (2010) asked 3- to 7-year-old children to evaluate whether their classroom activities with interactive whiteboards were playful or not. Unlike the teachers, the children evaluated the activities as not playful. In addition, having fun doing activities does not necessarily mean that children think that they are playing (Ólafsdóttir \& Einarsdóttir, 2017). 


\subsection{Structure of the dissertation}

This dissertation consists of two main parts: the summary and the articles. The summary presents the introduction, theoretical framework, research aims, and research questions. It also describes the methodological foundations and the concrete methods used in the empirical studies. In the results chapter, the findings of the empirical studies are discussed and compared by scrutinizing them through the theoretical concept of third space. Finally, it provides an evaluation of the research and suggests some implications for future research, teacher education, and the pedagogy of early childhood education. The second part consists of three articles published in international peer-reviewed journals. All of these have their own precise research questions or aims, which are introduced in the articles themselves and presented in the overview of the articles. 


\section{Theoretical framework}

The theoretical framework of this dissertation draws from two traditions: third space theory and teacher belief research. In this chapter, I first present an overview of both theories and articulate my perspectives in relation to the different interpretations within these fields of research. Then, I combine these frameworks as I argue that the third space, to a notable extent, is a space constructed from and around beliefs.

\subsection{Third space theory}

The concept of the third space dates back to Homi K. Bhabha's (1994) view of the hybrid space of immigrants between new and old cultures. In the broadest sense, the third space reflects that depending on the social and cultural context, variously constructed knowledge and discursive resources may be either enablers or limiters of one's self-expression and identity (Bhabha, 1994; Moje et al., 2004). The concept of the third space was first implemented in educational research by literacy scholars (Gutiérrez, Baquedano-López, \& Tejeda, 1999). During the 2000s, the concept has been applied to new-literacy research (e.g., Pahl \& Rowsell, 2005), as well as to (digital) media education (e.g., Rantala, 2009). In addition, scholars working in the field of blended and seamless learning (Rajala, Kumpulainen, Hilppö, Paananen, \& Lipponen, 2016) and play (Yahya \& Wood 2016) have recently drawn from third space research literature.

Third space theory offers several benefits for theorizing ICT integration. As argued by John Potter and Julian McDougall (2017, p. 16), third space theory can be used as an analytical device to "bring together a wide range of parallel but hitherto previously discrete contemporary discourses of digital media, education and culture." Stated differently, third space theory enables multidimensional research approaches in which the views and experiences of multiple stakeholders are brought into a negotiation (Moje et al., 2004) at (at least) two levels: Having views and experiences of different people brought into a negotiation and having different theoretical and discursive research traditions brought into negotiation. In the context of the present study, these dimensions are young children and childhood research and preservice teachers' and teachers' beliefs research.

Another advantage of third space theory lies in its links to socio-material theories (Gourlay, Lanclos, \& Oliver, 2015; Gutiérrez, 2008). Socio-materiality refers to the idea that materiality and sociality are deeply intertwined. Wanda 
Orlikowski (2007, p. 1437) defined socio-materiality as "the social and the material are considered to be inextricably related - there is no social that is not also material and no material that is not also social." Studies drawing from socio-materiality explore ways that human and non-human materialities (i.e., objects, artefacts, and tools) combine to produce particular purposes and particular effects in education by examining the messy textures woven through different kinds of networks - and the resulting ambivalences - that intersect in pedagogical processes (Fenwick \& Landri, 2012).

In the context of the present study, the key feature of socio-materiality is the idea that the way people interact with artefacts - such as digital devices and content - always reflects their lived experiences from the wider culture (see also Potter \& McDougall, 2017). As ICT integration in early childhood education is a new phenomenon, home is where young children's first encounters with ICT take place. Currently, the ICT used in early childhood education is to a great extent the same as children use at home (e.g., Chaudron et al., 2015; Dunn et al., 2016). This means that children have ICT-related experiences, knowledge, skills, views, values, and attitudes, and they do not gravitate toward ICT use in early childhood education from a tabula rasa position. In addition, the experiences children have shape the way they engage in ICT-mediated practices in preschool.

In third space theory, an either/or view is transformed into a both/also point of view (Zeichner, 2010) as it "resists the binaries of home and [pre]school, of formal an informal learning, and instead focus on what takes hold as children and youth move in and across the various settings and contexts of their everyday life" (Gutiérrez, 2008, pp. 150-151). This allows research to move beyond assimilative and differentiated conceptions of the settings in which children act regarding use of digital technologies and understand (pre)school as a dynamic (third) space where "people, ideas, and practices of different communities meet, collide, and merge" (Engeström, 2005, p. 46; see also Moje et al., 2004).

In the context of educational studies, the first space usually refers to children's informal learning contexts, while the second space refers to institutional education. The third space, in turn, is where these two domains are brought into a negotiation (e.g., Pahl \& Rowsell, 2005; Rantala, 2009). The concept can refer to a literal space (i.e., an after-school computer club), a virtual space (i.e., a blog written in school and at home), or - as in this study - a metaphorical space (Potter \& McDougall, 2017; Yahya \& Wood, 2016). Further, two different kinds of interpretations of the (metaphorical) third space can be found in previous research: a bridging space and an intersectional space. 


\subsubsection{The bridging interpretation of the third space}

In this conceptualization, the first and second spaces are represented as distinct, areas, and the third space acts as a bridge that unites them (e.g., Moje et al., 2004; Pahl \& Rowsell, 2005; Yahya \& Wood, 2016). A typical example of a bridging space is one in which a teacher recognizes things that are important for children in their informal learning contexts and integrates these things in pedagogical practices (e.g., Cook 2005). As stated by Leena Rantala $(2009,389)$, "creating third spaces could be seen as a pedagogical aim to enhance learning by giving space for out of school literacies including popular culture and multimodal texts." An illustrative case can be found in an ethnographical study by Annukka Lehtikangas and Heta Mulari (2016). In their article, they described how they observed a teacher encouraging and helping two boys to compose Ninjago short stories on a computer. Stories were also illustrated by searching for Ninjago pictures on the internet. In this example, the children's first space knowledge (knowledge about Ninjago) is used to learn conventional academic knowledge (print literacy skills; Moje et al., 2004; see also Dickie \& Shuker, 2014; Dyson, 2003, 2010), and the children and the teacher are "writing using home and school literacy" which Kate Pahl and Jennifer Rowsell (2005, p. 75) offered as an archetypical example of third space pedagogy in their illustration of a bridging third space (see Figure 1).

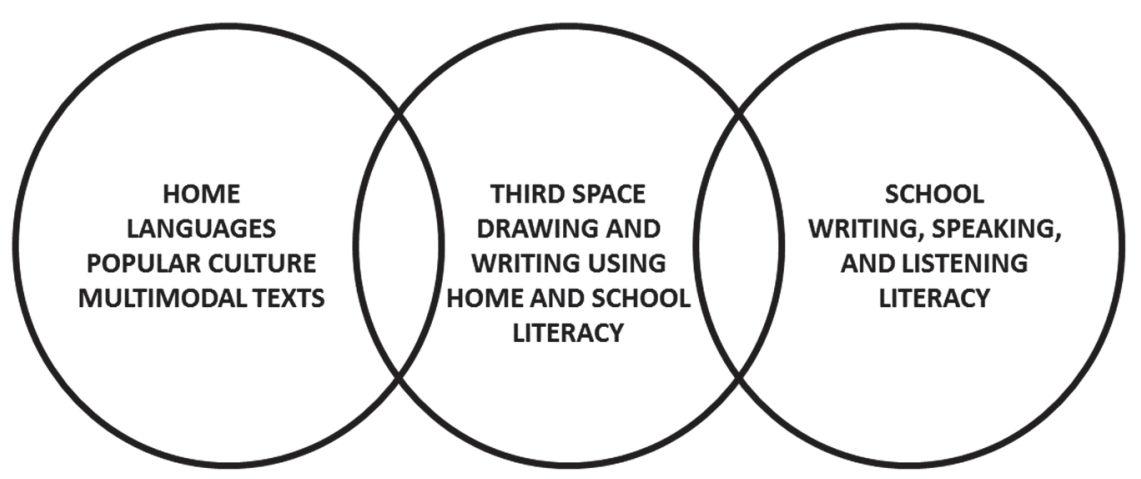

Fig. 1. The bridging interpretation of the third space (Pahl \& Rowsell 2005, p. 65; published by permission of Sage).

The bridging interpretation, however, is problematic for two reasons. The first is the unilaterally positive way the third space is represented in the model. Teachers 
do not always react to children's first space knowledge in a positive manner. To give an example, teachers tend to forbid children from performing media-related role-plays in preschool (Friedrichs-Liesenkötter, 2015; Pennanen, 2009; Ylönen, 2012). In these cases children's first space knowledge is recognized and reacted to by the teachers but in a manner in that restricts children's opportunities for selfdriven self-expression (Moje et al., 2004). This was also the case in Lehtikangas and Mulari's (2016) study. The boys were allowed to produce Ninjago stories but not to role-play Ninjago. It appears that children's first space experiences are given value and space only when they can be "pedagogized," which in this case meant integrating media-related themes with literacy-supporting practices (storytelling) approved by the teachers. As argued by Jackie Marsh (2006), teachers' positive attitudes tend to relate only to the way in which popular culture texts can be used to enhance motivation and orient children toward schooled literacy practices. Popular culture, per se, is seldom seen as a useful literacy practice in its own right.

The second shortcoming is the fundamental assumption that the actualization of the third space requires that teachers recognize the existence of a noninstitutional context (the first space) either in accordance with the established practices of the institutional context (the second space) or create new rules and practices (either enabling or restricting ones) around them. According to this view, the third space can emerge only if it is given space by the teachers (Rantala, 2009). However, it is simply impossible for teachers to be aware of the whole spectrum of first space knowledge reflected in children's activities and choices, and children can bring elements from the first space without teachers being aware of those elements. Children can also intentionally keep teachers ignorant as children are found to hide and disguise media-related role-plays they know the teachers would not approve (e.g., Lehtikangas \& Mulari, 2016; Pennanen, 2009).

\subsubsection{The intersectional interpretation of the third space}

To overcome these problems, in this study the third space is conceptualized as an intersection of first and second spaces. This interpretation is based on the view that first space knowledge and identities are always present when people enter the second space. According to Reijo Kupianen (2013, p. 37), "because children and young people use different media devices in their everyday life and have their own special media practices, they bring these practices to [pre]school as well." In addition, David Buckingham (2015, p. 22) argued that outside (pre)school, children engage with ICT not as mere technologies but as cultural forms, and if educators 
wish to use ICT in (pre)schools, they cannot afford to neglect these experiences. Thus, drawing on socio-material theories, it can be argued that children's first space cultures and experiences are included and shape second space practices regardless if the teacher recognizes children's first space-related experiences and knowledge.

An illustrative example can be found in the study by Suzanne Kjällander and Farzaneh Moinian (2014) in which they reported about a sequence of five children playing a tablet-based digital game in which they had to feed figures (a circle, rectangle, triangle, and square) to a "monster" as part of the teacher-initiated geometry practice. The monster asked for different forms to eat, and the application provided the children visual and spoken directions on the monster's forehead and the form the monster asked for. However, children mainly swiped randomly, and most often, they offered the monster the wrong form, which the monster refused to eat. The teacher tried to scaffold the situation by pointing to the correct form, naming it, and asking the children, "What is it the monster wants to eat?" As an answer, one of the children pointed to the monster and said, "It is dangerous!" Then one child swiped her finger in the monster's eyes. The monster screamed, "Ouch! Ouch!" Children took turns swiping their fingers in the monster's eyes and mouth, and they giggled and laughed (2014, pp. 22-23).

Based on the description of the situation, the children-despite the prompts given by the application and the teacher-had trouble relating to the game as a learning task. One reason could simply be a bad game design, but from the viewpoint of third space theory, that is not the whole story. Playing digital games has become a common practice among young children in contemporary Western societies (Chaudron et al., 2015), and in my interpretation, the example also signals that children are oriented toward playing the game according to the "rules" of digital gaming they have encultured in the first space. The comment "it is dangerous" by one of the children and the children's enthusiasm for irritating the monster by causing it pain imply that the monster is not considered a "pedagogical agent" " but an antagonist that needs to be defeated: a typical feature in digital games played by this age group (Chaudron et al., 2015; Suoninen, 2014). Similarly, in a study of the didactical difficulties of using commercial educational games, Vigdis Vangsnes, Nils Tore Gram Økland, and Rune Krumsvik (2012) found that when a teacher tried to start a dialogue by asking questions in order to make children go more thoroughly into a matter, the children concentrated too much on the game to

\footnotetext{
${ }^{9} \mathrm{An}$ animated pedagogical agent is a computerized character (either humanlike or otherwise) designed to facilitate learning (Craig, Gholson, \& Driscoll, 2002).
} 
pay attention to the teacher's meta-didactic intention. The authors concluded that the children and teacher in a gaming situation have different agendas: The playing child has a perspective of playing the game, while the teacher has an educational perspective. $^{10}$

Last, I argue that the third space is not a unified space but a set of micro-spaces that can be harmonious or tension-filled. Similar to other educational institutions, early childhood education is not a pure rational operating environment but a polyphonic meeting place of people with varying experiences, emotions, views, and values (see Elbaz-Luwsich, Moen, \& Gudsmundsdottir, 2002, p. 197). This is not restricted to a variation that exists between teachers and children. Teachers' ${ }^{11}$ views, beliefs, and attitudes toward if and how media and ICT should or should not be implemented in early childhood education vary (e.g., Lynch \& Redpath, 2014; Opetus ja kulttuuriministeriö, 2013). For example, in Marsh's (2006) study, one preservice teacher decided to use Pokémon cards to engage children in literacy and math although Pokémon was banned in the school where the study took place. Similarly to the children in Suvi Pennanen's (2009) study, the preservice teacher had to implement these practices out of sight of (other) teachers, and she commented that she was afraid of getting caught. Additionally, not all first space knowledge is treated accordingly by teachers. An illustrative example was presented in a study by Minna Ruckenstein (2010) in which she described how boys were banned from bringing hand-held gaming devices to preschool. Girls, however, were allowed to bring Tamagotchi devices ${ }^{12}$ as playing with them was associated with role-play and nurturing. To sum up, the decision whether the third space is an enabler or a limiter for children is not fully determined by the policy statements of (pre)schools but is negotiated repeatedly with different teachers and depends on the type of first space knowledge the children represent. The intersectional interpretation is illustrated in Figure 2.

\footnotetext{
${ }^{10}$ These contradictory perspectives are not limited to ICT-mediated practices. Stig Broström (2017, see also Sandberg et al., 2017) argued that in early childhood education there is often a disconnection between the motive and the goal in children's learning activities. Because of this disconnection, children do not get a direct experience of the meaning of the activity. Therefore, it is crucial that children achieve an understanding of the reason for the particular action and, in their minds, reflect on the relationship between the motive and the goal.

${ }^{11}$ This applies to children, too: Not all children have similar values and tastes regarding ICT use.

${ }^{12}$ A handheld digital pet.
} 


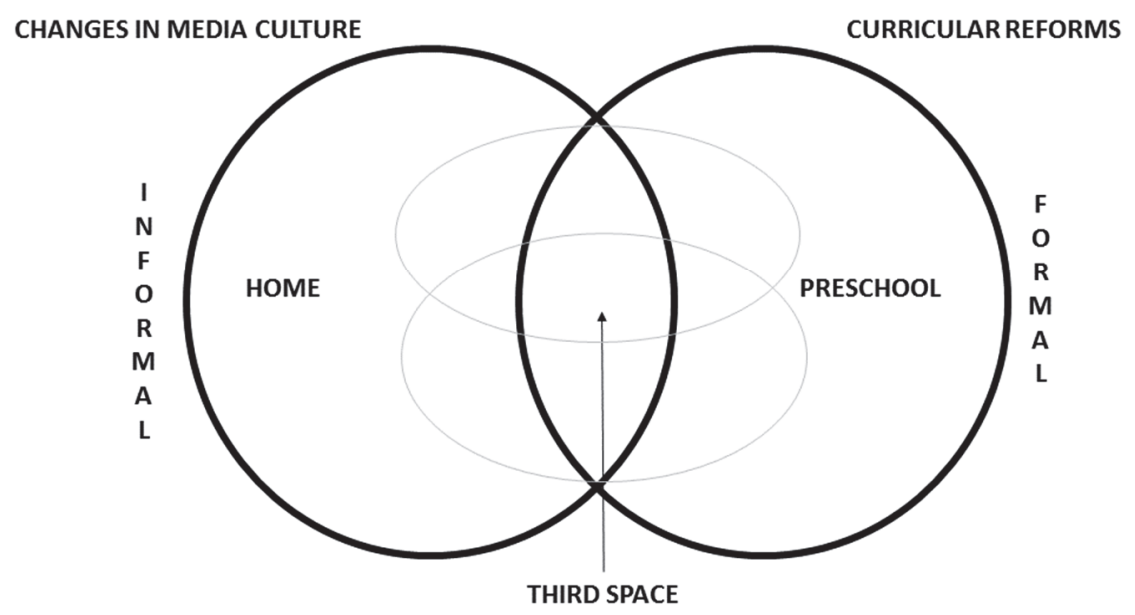

Fig. 2. Intersectional interpretation of the third space in the context of ICT integration in early childhood education.

\subsection{Teachers' beliefs}

The research on teachers' beliefs ${ }^{13}$ has a long history of more than 60 years (Ashton 2015: 31), and they are identified as one of the key factors that guide teachers' decisions and actions in classroom situations (e.g., Fang, 1996; Ertmer, OttenbreitLeftwich, Sadik, Sendurur, \& Sendurur, 2012; Stipek, Givvin, Salmon, \& MacGyvers, 2001). Beliefs are also considered to influence how and why teachers may or may not change their practice to incorporate a new curriculum, adopt new instructional strategies, or take up new initiatives (Biesta, Priestley, \& Robinson, 2015; Levin 2015, p. 50). Thus, it is not a surprise that teachers' beliefs have been a regular topic of research in the context of ICT integration (see the reviews in Kim, Kim, Lee, \& Spector, 2013; Tondeur van Braak, Ertmer, \& Ottenbreit-Leftwich,

\footnotetext{
${ }^{13}$ As argued by Frank Pajarers (1992), beliefs often "travel in disguise and under alias." This is also the case in this dissertation study as in Article III the participants' views are conceptualized as perceptions instead of beliefs. However, as the participants were discussing possible situations (what kind of ICT pedagogy they would carry out when they became in-service teachers and why), these notions can be also conceptualized as beliefs. The participating preservice teachers cannot know for sure that will be the way they act, but, that is a premise they felt was true and possible (see Richardson, 2003).
} 
2017), and they have even been called "the final frontier" on the way to ICT integration (Ertmer, 2005, p. 25).

Teachers' beliefs research can be divided into two main branches: research about what beliefs are (how they are constructed) and what beliefs are about (the content of beliefs; Fives \& Buehl, 2012). This dissertation focuses on the latter category - the content of the beliefs. Nevertheless, if one is about to conduct a research on beliefs, one must also express what one understands by beliefs. In the following two subchapters, I first articulate where I stand in relation to the question "what are the beliefs?" Then I explain what the content of the beliefs explored in this dissertation is and why these particular beliefs matter.

\subsubsection{Construction of teachers' beliefs}

Virginia Richardson (1996, 103, 2003, 2) defined beliefs as "psychologically-held understandings, premises or propositions about the world that are felt to be true." This widely applied characterization acts as the definition of beliefs in this dissertation, too. This said, although Richardson's (1996, 2003) definition describes what beliefs are, it says only a little about how they are constructed. Helenrose Fives and Michelle Buehl (2012) argue that researchers need to be clear about where they stand in relation to five constructional dimensions of beliefs: 1) knowledge/belief, 2) implicit/explicit, 3) individual/system, 4) situated/generalized, and 5) stable/dynamic.

In this dissertation, knowledge and beliefs are understood to be intertwined. To give an example, teachers have reported that children are more restless on Mondays than other weekdays in preschool (Friedrich-Liesenkötter, 2015; Puroila \& Haho, 2017). This phenomenon is commonly known as "Monday syndrome" in Germany, and the reason behind children's restlessness is argued to be that children spend the weekends in front of the television and do not do other activities that require physical effort (Friedrich-Liesenkötter, 2015). However, teachers do not have undeniable knowledge about how children have spent their weekends, and the conclusions and generalizations about the situation are beliefs.

When it comes to the question whether beliefs are conscious or tacit, I agree with Fives and Buehl's (2012) notion that teachers hold implicit and explicit beliefs. Furthermore, although beliefs are often represented as internal mental structures of individual teachers, beliefs are not formed in a vacuum but are always shaped within specific historical and material conditions (Nuttall, Edwards, Mantilla, Grieshaber, \& Wood, 2015). These conditions can refer to broader societal and 
cultural conditions. In a study of Egyptian science teachers, Nasser Mansour (2008) identified that mainly teachers' personal religious beliefs and experiences shaped the teachers' beliefs and practices. In addition, the traditions, norms, and pedagogical characteristics of certain educational domains shape teachers' beliefs. The current stage of research on teachers' beliefs in ICT integration in early childhood education has been criticized for relying on theories and data collection tools developed in and for other educational contexts (Blackwell, Lauricella, Wartella, Robb, \& Schomburg, 2013; Plumb \& Kautz, 2015). Last, regarding the question whether beliefs are stable or dynamic, I stand among those who propose that beliefs are a subject that can (if not easily) be changed. Research conducted in preservice teacher education suggests that beliefs can be changed if they are addressed, critically reflected, and evaluated with intentional interventions (e.g., Brownlee, Purdie, \& Boulton-Lewis, 2001; Isikoglu 2008). In addition, Joanne Brownlee's (2003) longitudinal study of changes in primary school teachers' epistemological beliefs showed that beliefs can change with no intentional external intervention.

\subsubsection{Content of teachers' beliefs}

Teachers are found to hold beliefs about many things, including beliefs about knowledge, their students, the context in which they work, subject matter, as well as moral dilemmas and societal issues that affect their work (Biesta et al., 2015; Fives \& Buehl 2012, p. 472; Levin 2015, p. 48). Grounded in an extensive review of studies, ChanMin Kim et al. (2013) criticized research on teachers' beliefs in the ICT integration context for having a narrower perspective on beliefs than in research on teachers' beliefs in general. They argued that researchers tend to examine beliefs associated only with technology and stated that "in order to understand why technology is integrated differently among teachers, their fundamental beliefs about what is important in student learning and thus teaching (regardless of technology use) should be understood" (2013, p. 77).

A review of studies performed in the context of early childhood education supports the critique as ICT-associated beliefs are not explored in relation to teachers' general beliefs (e.g., Blackwell, Lauricella, \& Wartella, 2014; Jimoyiannis \& Komis, 2007; Nikolopoulou \& Gialamas, 2015). I agree with Kim et al. (2013) about the importance of expanding the scope to study fundamental beliefs regarding learning and teaching and how they are related to ICT-related beliefs. That being said, given the broad spectrum of teachers' beliefs, focusing on 
beliefs about learning and teaching fails to recognize the multidimensional and complex nature of being (and becoming) a teacher. Teachers, regardless the age of their students, have reported that in addition to teaching the curriculum and academic skills their task is to take care of the "whole child" (Lasky, 2005) by addressing aspects of care in their work (e.g., Estola, Erkkilä, \& Syrjälä, 2003; O'Connor, 2008; Vogt, 2002). In other words, teachers do not make decisions based only on beliefs about on how children learn but based on a more holistic and complex view of children, teacherhood, and the essence of institutional education.

\subsection{The third space as a space of beliefs}

In this chapter, I argue that the third space is - to a notable extent - a space of beliefs. I focus on two themes: Teacher's beliefs about children's experiences with ICT at home (beliefs about children's first space) and teacher's beliefs about the essence of early childhood education or, put differently, what early childhood education is for and about (beliefs about the second space). These themes are discussed in separate subchapters. I point out that teachers have beliefs about children's experiences with ICT at home and that these beliefs shape the teachers' pedagogical decisions and practices. Then, I argue that teachers' general beliefs about what early childhood education is shapes their disposition toward ICT integration. Figure 3 presents how teachers' beliefs are located in the third space framework. 


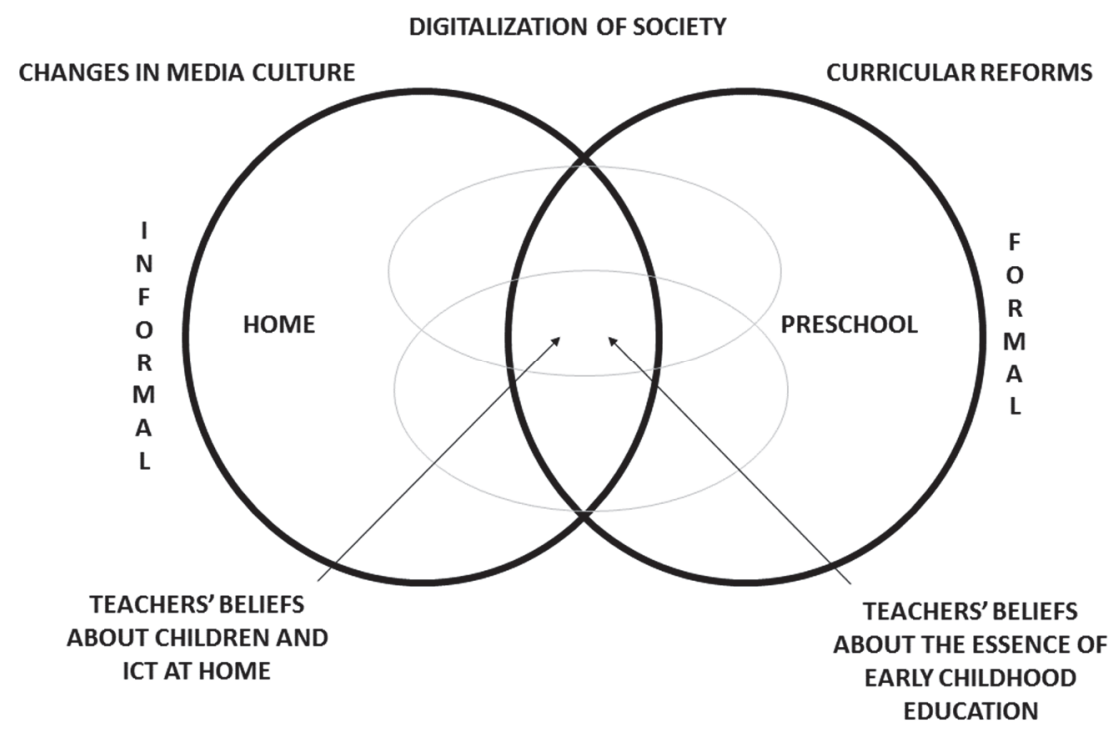

Fig. 3. Locating teachers' beliefs in the third space framework.

\subsubsection{Teachers' beliefs about children and ICT at home (the first space)}

According to previous research, teachers have positive and negative beliefs regarding children's use of ICT at home (e.g., Friedrichs-Liesenkötter, 2015; Ihmeideh \& Alkhawaldeh, 2017). To give an example of positive beliefs, ICT use at home is believed to provide children skills and knowledge which - in a good way-distinguish them from previous generations. This viewpoint is well captured in the following extract from a study by Fathi Ihmeideh and Mustafa Alkhawaldeh (2017, p. 144):

This generation that we teach is completely different from previous generations especially our generation when we were their age. We notice how this generation is far more knowledgeable, mature and aware of life compared to other generations; this is a result of their excessive use of TDM [technology and digital media] like televisions, tablets, computers, and Internet.

Not all teachers share this view, and preservice and in-service teachers have expressed concerns that due to children's excessive use of ICT at home, preschool 
should be a technology-free space (Friedrichs-Liesenkötter, 2015; Lehtikangas \& Mulari, 2016). However, it is crucial to acknowledge two things. The first is that teachers have reported that they are not well aware of children's actual home-based ICT experiences (Aubrey \& Dahl, 2014; Dong \& Newman, 2016), and the presumptions about children's ICT use at home are mainly interpretations made from the themes of children's role-play (Nuttal et al., 2015; Ylönen, 2012). However, the assumption that children's role-play reflects their ICT experiences precisely is questionable; knowledge about digital culture is cultural and social capital among children (Aarsand, 2010), and children can rely on secondary sources to get the information needed to participate in a role-play (Lehtikangas \& Mulari, 2016; Salomaa \& Mertala, in press). Second, these beliefs are about the youngest children, whose actions and routines are, to a large extent, determined by their parents. Thus, beliefs about children's ICT use in the home are intertwined with beliefs about parents and home rearing. Put another way, early childhood teachers' concerns about children's ICT use means that they assume that parents allow their children to use too much and/or the wrong kinds of ICT (Friedrichs-Liesenkötter, 2015; Ylönen, 2012). In addition, beliefs about parents' own ICT use has caused distress among teachers as they have expressed their concern that children are denied early language learning opportunities because their carers or parents spend time texting rather than talking to their children (Flewitt et al., 2015).

Discriminating beliefs about the quality of parenthood are not restricted to ICTrelated questions: Previous research suggests that preservice teachers' views of parents are polarized and that teachers do not have much understanding of the nuances and complexity of being a parent and family life in general (Baum, 2000; Baum \& McMurray-Swartch, 2004). According to Catherine and Joseph Meehan (2017), many preservice teachers fail to see children's safety as the prime concern of all parents and consider that parents perpetrate or harm their children's growth. This notion is supported by Angela Baum and Paula McMurray-Swartch (2004) who claimed that many preservice teachers seem to adopt an "us versus them" attitude toward work with parents and that they are educating children "in spite" of their parents, rather than in partnership. Last, preservice teachers are found to believe that due to their training their knowledge of children is more relevant than parents' knowledge (Graue, 2005). 


\subsubsection{Teachers' beliefs about the essence of early childhood education (the second space)}

In addition to teaching, the aspects of care and education are inseparable parts of being and becoming a teacher (e.g., Lasky, 2005; Niikko 2004; O'Connor 2008; Vogt, 2002). This holistic understanding of the role of institutional education is most prominent in early childhood education, especially in the Nordic context, where early childhood education is conceptualized through the EDUCARE model consisting of education, teaching, and care $^{14}$ (e.g., Broström, 2006; Onnismaa \& Kalliala, 2010). For example, the Finnish National Core Curriculum Guidelines for Early Childhood Education (Opetushallitus, 2016, p.21) state that "education, teaching, and care form a harmonious whole" which "allows a holistic approach to the child's growth, development, and learning."

\section{Teaching, education, and care: Definition of the concepts}

Teaching, education, and care are all complex and multidimensional concepts, which are defined differently in different contexts. As this dissertation is written from the perspective of Finnish early childhood education, the meaning of the concepts of teaching, education, and care is opened up in accordance with the Finnish National Core Curriculum of Early Childhood Education (Opetushallitus, 2016). Teaching here is understood as supporting and promoting children's learning, and thus, teaching can be described as a process through which children construct knowledge and skills (e.g., Broström, 2006; Puroila, 2002). Education, in turn, refers to decisions about which cultural values, habits, and norms should be transmitted in early childhood education and which should be shaped and regenerated (e.g., Biesta et al., 2015; Johansson, Puroila, \& Emilson, 2016; Niikko, 2004). When approached as care, the key task of early childhood education is to meet children's needs by providing physical care and having a caring attitude toward children (e.g., Einarsdóttir, 2003; Van Laere \& Vandenbroeck, 2018).

Another branch of debate has concentrated on the way these impressions relate to each other. It has been argued that education and care are inseparable concepts,

\footnotetext{
${ }^{14}$ Other scholars use different concepts to address the same topics. For example, Broström (2006) used the term "upbringing" and Niikko (2004) the term "socialization" to define what here is referred to as "education." Puroila (2002), in turn, used "education" to define what here is referred to as "teaching." The decision to use the terms "teaching," "education," and "care" is drawn from the terminology of the Finnish National Core Curriculum (Opetushallitus, 2016).
} 
and thus, there are no meaningful distinctions between care and education for young children (e.g., Sheridan et al., 2011; Smith, 1993). I agree that - especially at the level of everyday pedagogical practices - making clear-cut distinctions between these three concepts is artificial as teachers can carry out practices and discourses in which several roles are intertwined (Einarsdóttir, 2003; Puroila, 2002). However, although in everyday situations teaching, education, and care are not fully separable and independent concepts, they still provide a useful framework for analytical exploration of the different tasks and dimensions of early childhood education (e.g., Broström, 2006; Salomaa, 2016).

Previous research has also identified that teachers distinguish between teaching, education, and care in their everyday work. Some teachers consider teaching their main work (Van Laere \& Vandenbroeck, 2018; Ylitapio-Mäntylä, 2009), while others have emphasized education (Niikko, 2004) and care (Einarsdóttir, 2003; Ylitapio-Mäntylä, 2009). No unambiguous explanations cause these differences. One explanatory factor seems to be how early childhood education is provided: Teachers working in countries with split systems ${ }^{15}$ tend to emphasize teaching (Van Laere \& Vandenbroeck, 2018) whereas in countries with integrated systems (such as Finland), teachers move between different professional roles and expectations and are better able to see connections between different orientations (e.g., Einarsdóttir, 2003; Niikko \& Ugaste, 2012). In addition, children's age appears to play a role in teachers' orientations. According to Outi Ylitapio-Mäntylä (2009), care is a salient frame when teachers work with the youngest children ( $0-2$ years old), while teaching is emphasized when teachers work with older children, especially with those in pre-primary education (6 years old).

\section{EDUCARE and ICT integration}

Teaching, education, and care also play a role in teachers' beliefs about ICT integration. As discussed in Subchapter 2.3.1, some teachers believe that children's ICT use at home is excessive, and thus, early childhood education should be a technology-free space (e.g., Friedrichs-Liesenkötter, 2015; Lehtikangas \& Mulari, 2016). Research suggests that such view is justified either through the educational or caring frame. The educational orientation is apparent in beliefs that due to excessive ICT use traditional play and outdoor activities no longer are a regular

\footnotetext{
${ }^{15}$ Split system refers to a system in which childcare and early education are provided by different stakeholders (Moss, 2006).
} 
part of young children's lives at home (e.g., Flewitt et al., 2015; Istenic Starčič, Cotic, Solomonides, \& Volk, 2016). In this case, one of the key tasks of early childhood education is thought to be to ensure that children get their share of traditional play and outdoor activities. In other words, teachers react to the (perceived) changes in children's (first space) lifeworld (Hernwall, 2016) with educational actions that can be described as protective mediating (Osborn, Croll, Broadfoot, Pollard, McNess, \& Triggs, 1997). Teachers are protecting children from unwanted societal change, and they consider curricular ICT integration pressure to change pedagogical practices in early childhood education (Lindahl \& Folkesson, 2012b).

The caring orientation is apparent in beliefs that children's ICT use at home is threatening children's health. Long hours spent on screens are thought to raise children's state of alertness and cause restlessness (Blackwell, 2013; FriedrichsLiesenkötter, 2015), as well as cause problems for children's physical posture (e.g., Ihmeideh, 2009; Palaiologou, 2016b). In these cases, the role of early childhood education is to take care that children have the needed respite from screen-based activities, as well as enough physical exercise. Some teachers, in turn, consider ICT use in early childhood education necessary to prepare children for changing society: $58 \%$ of the teachers in a study by Nicole Fenty and Elizabeth McKendry Anderson (2014) agreed with the statement that electronic media will replace printed text within the next five years, and thus, early childhood education must provide children the skills needed for full citizenship in the "high tech world" (see also Izumi-Taylor, Ito, \& Gibbins, 2010). Sometimes, preparation means learning basic operational skills, such as using the mouse or keyboard (Ramírez, Clemente, Recamán, Martín-Domínguez, \& Rodrígue, 2017). At other times, more sophisticated goals were expressed. For example, one teacher in Helen Knauf's (2016) study commented that improving children's understanding of online safety and privacy matters is one of the main educational goals for ICT use in her class. ICT use in early childhood education is also regarded as preparation for children's future schooling (Marklund \& Dunkels, 2016; Palaiologou, 2016b). Such views are expressed often by individuals who work in pre-primary education (Lindahl \& Folkesson, 2012a; Mertala 2017) which suggests that the age of children has a role in teachers' beliefs about ICT use in early childhood education (see also Dong \& Newman, 2016). ICT use in early childhood education is also understood to have an affirmative role, as not all children have equal access to computers at home (Friedrichs-Liesenkötter, 2015). 
Teachers have also reported beliefs that ICT has a lot to offer for teaching young children. Although in general beliefs teachers have emphasized learning socioemotional skills (e.g., Kowalski, Pretti-Frontczak, \& Johnson, 2001; Lee, 2006), ICT is most often considered a tool for supporting children's learning of academic subjects, namely, literacy and math (e.g., Blackwell, Lauricella, \& Wartella, 2016; Brown \& Englehardt, 2017; Ingleby, 2015). The literature offers no comprehensive account for why ICT is mostly seen as a tool for academic excellence. One reason could be that the benefits of ICT use are often promoted by educational authorities (see Tondeur, van Braak, Sang, Voogt, Fisser, \& OttenbreitLeftwich, 2012). Ewan Ingleby (2015) described how British governments have been propagating a pro-technology ideology that "e is the best" for learning, and he stated that this hegemonic dogma could be identified from teachers' beliefs which were profoundly positive. Another possible explanation is that teachers have been found to use technological affordances as the starting point of their ICT pedagogical planning (Dong \& Newman, 2016; Mertala, 2017). Analyses of educational mobile applications for young children showed that the supply is dominated by applications (apps) advertised to promote learning of literacy and mathematics (Papadakis, Kalogiannakis, \& Zaranis, 2018; Vaala, Ly, \& Levine, 2015). 


\section{Aims of the study and the research question}

The general aim of this dissertation study is to move beyond approaching ICT integration as either assimilation or differentiation by applying a framework which acknowledges both-children's informal ICT experiences and the unique pedagogical nature of early childhood education. To achieve these aims, I collected two data sets. One data set came from young children (see Article I) and the other from preservice teachers (see Articles II and III). Each published article has its own specific research questions that are reported in the articles. The overarching research question for this dissertation study is as follows:

What are the key characteristics of the third space of ICT integration in early childhood education when this space is constructed from children's ideas and preservice teachers' beliefs?

The overarching research question is approached through four sub-questions:

1. How are informal ICT cultures reflected in children's ideas for ICT use in early childhood education?

2. How are pedagogical cultures of early childhood education reflected in children's ideas for ICT use in early childhood education?

3. What beliefs do preservice teachers have about children's informal experiences with ICT, and what is the role of these beliefs in preservice teachers' beliefs about the role of ICT in early childhood education?

4. What beliefs do preservice teachers have about the essence of early childhood education, and what is the role of these beliefs in preservice teachers' beliefs regarding ICT integration? 


\section{Methodological considerations}

In this chapter, I present an overview of the qualitative research methodology that guided the research process. I begin by explaining what I understand about qualitative research methodology. Then, I provide an overview of the qualitative research methods and locate this dissertation on the continuum of qualitative research.

\subsection{Qualitative research as a research methodology}

According to Gert Biesta (2010), a distinction can be made between research that seeks to explain and research that seeks to understand. The ambition of explanatory research is to identify causes, factors, or correlations and through this, generate knowledge that can be used to influence the course of future events. The ambition of interpretative research, in turn, is to generate understanding through an articulation of intentions and reasons for action (Biesta, 2010, p. 104). Similar arguments are used to describe the differences between quantitative and qualitative research: the former seeks correlations and causalities (Hopkins, 2008) while the latter aims to discover the essential qualities of a certain phenomenon (Miles, Huberman, \& Saldana, 2013, p. 282). That being said, Biesta's (2010) arguments had nothing to with the concrete methods of the research but were about the epistemological and ontological underpinnings behind the research questions and methods. In other words, qualitative or interpretative research is more than using data and methods that are commonly connected to this particular research paradigm. It is a way to approach the world and its phenomena. The same applies naturally for quantitative or explanatory research.

An exemplifying way to approach this dichotomy is to look at the ongoing discussion about the epistemological and methodological questions and challenges of mixed methods research. According to Joseph Maxwell and Kavina Mittapalli (2010, p. 148), the main argument for combining qualitative and quantitative paradigmatic positions and methods in mixed methods research has traditionally been their complementarity. Using them together allows the researcher to draw conclusions that would not be possible by using either method alone. The traditional way of doing mixed methods research is to collect and analyze two kinds of data: one which is qualitative and one which is quantitative (e.g., Biesta 2010; Creswell \& Plano Clark, 2007). Researchers who have applied mixed approaches have commented that their research acknowledges positivist (quantitative) and 
constructivist (qualitative) research paradigms (Näykki, 2014, p. 44). Several scholars, however, have suggested that research should move beyond such a binary understanding of knowledge and research as this distinction is considered superficial (e.g., Maxwell \& Mittapalli, 2010; Onwuegbuzie \& Combs, 2010). Isadore Newman and Carolyn Benz $(1998,9)$ have tried to tackle the dichotomy problem by proposing that instead of treating qualitative and quantitative research as separate entities they should be understood as a continuum. According to Newman and Benz (1998, p. 9):

Conceptualizing the dichotomy (using separate and distinct categories of qualitative and quantitative research) is not consistent with the coherent philosophy of science and, further, that the notion of a continuum is the only construct that fits what we know in a scientific sense.

Newman and Benz's (1998) argument finds the target especially in the use of methods and discourses labeled either qualitative or quantitative. As argued by Lee Sechrest and Souraya Sidani (1995, p. 79), qualitative researchers are frequently using terms such as "many", "most", "several", never" and so on, which are fundamentally quantitative. Matthew Miles et al. (2013, p. 282) continue by stating that a lot of counting goes on in the background when judgements of qualities are being made. For example, the use of cross-tabulations and frequency counts are common features in qualitative research (Denzin \& Lincoln, 2011, pp.8-9). According to Biesta (2010, p. 100; see also Dey, 2003) combining numbers and texts does not raise any particular problems, neither of a philosophical nor of a more practical nature. We can just see numbers and text as two forms of information and, more generally, two modes of representation ${ }^{16}$. These notions are supported by Anthony Onwuegbuzie, John Slate, Nancy Leech, and Kathleen Collins (2007) who argue that mixed method research can be carried out by using only types of data that considered as qualitative. Also Julianne Cheek (2011, p. 264) contends that mixed methods can be considered as one form of qualitative inquiry. This means, that even if the researcher uses methods and discourses that are linked to quantitative research, this does not mean that he or she is moving between different and conflicting paradigms. If mixed methods are used within qualitative research, then the quantitative analyses are based on and interpreted from the same epistemological and ontological foundations and frames as the qualitative analyses. In short, the researcher mixes methods (i.e., data collection and analysis

\footnotetext{
${ }^{16}$ For example, for a sports fan, "0-0" and "goalless draw" are such representations.
} 
procedures), not methodologies (i.e., epistemological and ontological presumptions; see Twining, Heller, Nussbaum, \& Tsai, 2017).

\subsection{Qualitative research methods}

Although there is no one generally accepted definition of what is meant by qualitative research (e.g., Denzin \& Lincoln, 2011; Erickson, 2011, Potter, 1996), Norman Denzin and Yvonna Lincoln (2011, p. 3) argued that an initial, generic description can be offered:

Qualitative research is situated activity that locates observer in the world. Qualitative research consists of a set of interpretative material practices that make the world visible ... They turn the world into a series of representations, including field notes, interviews, conversations, photographs, recordings, and memos to the self. At this point qualitative research involves an interpretative, naturalistic approach to the world. This means that qualitative researchers study things in their natural settings, attempting to make sense or interpret phenomena in terms of the meanings people bring to them.

Qualitative data is often collected as field work, and the researcher is the instrument (Patton 2002, p. 4, 14). This means that the researcher's subjectivity is intimately involved in the research process (Ellingson, 2011; Ratner, 2002). Qualitative researchers use various data collection methods, including observation (e.g., Angrosino \& Rosenberg, 2011), interviews (e.g., Kvale \& Brinkman, 2009), field notes, photographs, and drawings (e.g., Einarsdóttir, Dockett, \& Perry, 2009). Data is not understood to capture the world around us as such but subjective representations of it (Denzin \& Lincoln, 2011, p. 415). Thus, instead of focusing on sample size, qualitative researchers are more interested in the richness and thickness of the data. Richness refers to the quality of the data and thickness to the quantity of the data. Patricia Fusch and Lawrence Ness (2015, p. 1409) stated, "thick data is a lot of data; rich data is many-layered, intricate, detailed, nuanced and more." Good qualitative data is rich and thick (Fusch \& Ness, 2015). It is rich is enough to be able to represent the complexity of a socially constructed reality and thick enough for the researcher to make comparisons and form categories. Such data can be provided even by only one participant if he or she is selected purposefully (Donmoyer 2000, p. 48). Purposeful means that the information the participant is able to provide is important for and in line with the central purpose of the inquiry (Patton, 2002, p. 230). 
As there are no clear-cut rules for how to collect qualitative data, no universal rules for analyzing it exist. Traditionally, the two main approaches for data analysis are deductive (theory driven) and inductive (data-driven analysis). Deductive analysis is used when the purpose of the study is to test the theory, and inductive analysis is used when theoretical categories are derived from the data (e.g., Elo \& Kyngäs, 2008; Twining et al., 2017). Due to the interpretative nature, inductive approaches are more common in qualitative inquiries (Pope, Ziebland, \& Mays, 2000). That being said, several scholars have challenged the idea of whether reasoning can be purely inductive. It has been stated that reasoning never takes place in a theoretical vacuum (e.g., Chenitz \& Swanson, 1986; SaaranenKauppinen \& Puusniekka, 2006), but the theoretical stance can often be implicit rather than explicit (Braun \& Clarke, 2006). To overcome the inductive-deductive debate, a third approach, abductive analysis, was introduced. The abductive approach discards the idea that the researcher's observations and interpretations can be purely inductive and acknowledges that a guiding theoretical thread is always included in the analysis (Grönfors, 2011; Saaranen-Kauppinen \& Puusniekka, 2006). However, unlike in deductive analysis, following a theoretical thread does not mean that the theory is taken as given or that the role of the analysis is simply to test the theory. Instead, in abductive analysis, the researcher moves between and combines inductive reasoning and existing theoretical models to open up new ways of theorizing the phenomenon under investigation (Dey, 2003, pp. 90-92; Suddaby, 2006; Tuomi \& Sarajärvi, 2012, p. 97).

\subsection{Locating the study on the qualitative continuum}

As discussed in the previous chapter, many different ways to approach and to practically carry out qualitative research exist. Laura Ellingson (2011) suggested that different qualitative research approaches can be better understood by placing them on a continuum. Drawing from the work of W. James Potter (1996), she (2011, p. 596) argued that,

a continuum approach to mapping the field of qualitative methodology constructs a nuanced range - or broad spectrum - of possibilities to describe what traditionally have been socially constructed as dichotomies such as $\mathrm{art} / \mathrm{science}$, hard/soft, and qualitative/quantitative.

On the "far right" of the continuum, the research includes the use of passive voice, an attempt to discover an objective truth that is "out there," deductive 
analysis methods, presentation of the researcher as irrelevant to the results, and research reports that rely on tables, figures frequency counts, and conventional academic layouts. On the "far left" of the continuum, the research includes the use of first-person voice, an attempt to construct personal truths, art-based methods, the researcher is more or as much the focus as the other participants, and use of experimental forms of research reports. In "the middle" are studies that use firstperson voice, explore how participants understand their world, focus more on participants than on the researcher but acknowledge the subjectivity of the researcher's interpretations, use a vast array of data collection and analysis methods, and rely on traditional methods of reporting the research (Ellingson, 2009, 2011).

I locate this dissertation on the middle of Ellingson's $(2009,2011)$ qualitative continuum. My goal is not to discover an objective truth or to explain reality "out there" but to make sense and interpret phenomena in terms of the meanings people bring to them (Denzin \& Lincoln, 2011, p. 3). Participants are the main focus, but I understand that my background and positionality affect the research questions and interpretations. The researcher's subjectivity is appointed by using a first-person voice instead of passive voice which connotes objectivity. The types of datadrawings and interviews (see Article I) and written assignments (see Articles II and III) - are all typical in qualitative inquiry (Patton, 2002) but are more on the traditional side than on the experimental side of the forms of qualitative data. The abductive approach for analysis (Dey, 2003; Grönfors, 2011) and the particular analysis methods used in individual studies - qualitative-oriented monotype mixed analysis (Onwuegbuzie et al., 2007) in Article I and constant comparative analysis (e.g., Fram, 2013; Suddaby, 2006) in Articles II and III-are interpretative rather than explanatory. 


\section{Methods used in the study}

In this chapter, I provide an account of the research methods, including an introduction to the participants, a description of the research contexts, as well as reports of the data collection and analysis. An overview of the methods used in the empirical studies is provided in Table 1.

Table 1. Summary of study methods.

\begin{tabular}{lll}
\hline Description & Article I & Article II \& III \\
\hline $\begin{array}{l}\text { Participants } \\
\text { Research context }\end{array}$ & $\begin{array}{l}\text { 5- to 6-year-old children (N=103) } \\
\text { Development project taking place in }\end{array}$ & 1st-year preservice teachers (N=38) \\
& $\begin{array}{l}\text { Compulsory educational technology } \\
\text { five preschools }\end{array}$ & course \\
Aim & $\begin{array}{l}\text { Explore children's ideas for ICT use } \\
\text { in early childhood education }\end{array}$ & $\begin{array}{l}\text { Explore preservice teachers' beliefs } \\
\text { about children and ICT at home (Article }\end{array}$ \\
& & II) and the role of ICT in early childhood \\
& & education (Article III) \\
Data & Drawings and interviews (103 & Written pre-course assignments (72 \\
& pages) & pages) \\
Analysis method & Monotype mixed analysis & Constant comparative method \\
\hline
\end{tabular}

\subsection{Participants, context, and the research design}

The data used in the dissertation was collected in two contexts. The data used in Article I was collected from 5- to 6-year-old children ( $\mathrm{N}=103$ [49 girls and 54 boys]) at five kindergarten-based pre-primary groups in a city in northern Finland. The groups participated in a development project funded by the Finnish National Board of Education. The aim of the project was to explore the pedagogical possibilities of affordable ICT equipment that could later be implemented in other settings. The data collection took place in October 2013, during the orientation period when ideas for the types and uses of ICT were gathered from children, their families, and preschool personnel and before any new ICT devices were purchased. This approach served two purposes. First, the ideas and views of all the stakeholders were asked to be taken into consideration to avoid the possibility of a technical intervention in which the developmental goals and the methods for reaching them would be defined by actors outside the learning community (see Carr \& Kemmis, 1986). Second, the development project was understood as an important opportunity to perform research in ICT integration in early childhood education, which, at the time, was little studied at the national level. 
Data for Articles II and III was gathered from first-year preservice teachers in a Finnish university-based early childhood teacher training program. The data collection took place during the middle of the respondents' first semester in November 2014 when the participants were attending an educational technology course in which I was the teacher. A total of 38 students participated in this study. Thirty-five were female, and three were male. The youngest participant was 18 years old, the oldest 37 years old, and the mean age was 23 . The value of studying first-year teacher students is that beliefs that have arisen before training are found to play a substantial role in determining whether preservice teachers adopt or reject new information and practices during their training (e.g., Levin, 2015; Richardson, 2003), because people tend to assimilate new information based on their existing beliefs (Nespor, 1987).

\subsubsection{Using drawings to explore children's ideas}

The research on children's drawing has a long tradition of analysis through graphic, perceptive, and psychological lenses. However, recently, drawing has been recognized as a form of narration and knowledge construction (Einarsdóttir et al., 2009). According to Angela Anning and Kathy Ring (2004, p. x; see also Einarsdóttir, 2007), children's drawings are a useable tool for knowing what children are telling us and give us adults a chance to take a glance at the children's thinking and understanding of the world. However, drawings are not representations of the world as such. In Anne Haas Dyson's (2003) study, children drew themselves visiting their classmates' homes, but according to the children's parents, they had not ever done so. In the drawings, the children were not recalling past experiences but symbolizing their friendship. Drawings also reflect the societal, cultural and communicational systems around children and children often include the names and logos of popular brands and the characters of favorite games and TV shows, as well in their drawings (Selwyn et al., 2009; Ylönen, 2012).

Using drawing as a data collection method can be described as child-centered as drawing is an enjoyable and beneficial activity for most children (Burkit, Watling, \& Murray, 2011; Horn \& Giacobbe, 2007, 52; Oskarsdottir \& Einarsdóttir, 2017) ${ }^{17}$ and a natural form of action in early childhood education (Kress \& vanLeeuwen,

\footnotetext{
${ }^{17}$ This applies best for the youngest children. As noted by Samantha Punch (2002, p. 331), "particularly older children, are more inhibited by a lack of artistic competence, and may not consider drawing to be a fun method."
} 
2006, 16). In past years, children's drawings have been used to explore various topics, including experiences of sadness (Steyn \& Moen, 2017), perceptions of consumption and friendship (Lundby, 2013), knowledge of the human body (Driessnack \& Gallo, 2013), valued school experiences (Steerlasky, 2017), and representations of nature (Ulker, 2012). Children are often interviewed based on what they have drawn. According to Johanna Einarsdóttir (2007; see also Punch, 2002), children's narratives and interpretations of their drawings can give a better picture than adults' interpretations of the drawings. The strength of combining visual and verbal narration is that by using the drawing - or some other visual medium - as a mediating tool, different parties are better able to understand each other's thinking by creating a transitional space in which their thoughts and ideas can be externalized into a concrete form (Horn \& Giacobbe, 2007; Lipponen, Rajala, Hilppö, \& Paananen 2016; Prosser, 2011; Spyrou, 2011).

In the present study, I applied the procedure called "the draw and tell conversation method" (DTC) (Driessnack, 2006; see also Prosser, 2011, pp. 491492) to collect children's ideas. In DTC, children are first given a specific art directive that reflects the study's purpose. When the drawing is ready, a conversation facilitated by an interview guide is carried out. ${ }^{18}$ The context in which the drawings are made and the audience to whom they will be shown are meaningful for the children's drawing experience (Burkitt et al., 2011; Einarsdóttir et al., 2009). This applies to the physical context (Patton, 2002, p. 280; Punch, 2002) and the socioemotional context (Burkitt, et al., 2011; Steyn \& Moen, 2017). Table 2 presents the types of equipment found on the premises. The listing is based on reports of the teachers and my observations.

Table 2. ICT devices found on the premises of the participating groups.

\begin{tabular}{ll}
\hline Group & Type of equipment found on the group's premises \\
\hline Group 1 & $\begin{array}{l}\text { Laptop and smartphone for staff; desktop computer for children (not in use due to technical } \\
\text { problems); digital camera and CD player for staff and children }\end{array}$ \\
Group 2 & $\begin{array}{l}\text { Desktop computer, smartphone, document camera, and canvas for staff; two CD players for } \\
\text { staff and children }\end{array}$ \\
Group 3 & $\begin{array}{l}\text { Laptop, smartphone, projector, and CD player for staff; interactive whiteboard for staff and } \\
\text { children (not in use due to technical problems) }\end{array}$
\end{tabular}

\footnotetext{
${ }^{18}$ In the present study, no recordings were made, but the children's comments were written down on the drawings, which is a common method in studies that use children's drawings as data (e.g., Einarsdóttir et al., 2009; Prosser, 2011, Steyn \& Moen, 2017).
} 


\begin{tabular}{ll}
\hline Group & Type of equipment found on the group's premises \\
\hline Group 4 & $\begin{array}{l}\text { Laptop, smartphone document camera, and projector for staff; interactive whiteboard for staff } \\
\text { and children }\end{array}$ \\
Group 5 & $\begin{array}{l}\text { Desktop computer and smartphone for staff; desktop computer for children (not in use due to } \\
\text { technical problems) }\end{array}$ \\
\hline
\end{tabular}

Children tend to lack experience communicating directly with unfamiliar adults (Punch, 2002). To provide the children a safe and familiar environment, the data collection was carried out by the teachers and nurses (Steyn \& Moen, 2017) who were provided written instruction for how to introduce the task to the children and how to carry out the interview. In summary, the children were asked to draw what kind of ICT they would like to have in preschool and what should be done with it. After the drawing was done, the children were interviewed. The instructions are reported in detail in Article I. Children were also informed about the forthcoming development project and that the ideas they drew and discussed would be taken into consideration in planning the project activities.

\subsubsection{Using written assignments to explore preservice teachers' beliefs}

Interviews are perhaps the most frequently used data collection method in qualitative research. In the context of the present study, the decision to use written assignments instead of research interviews was based on the nature of the relationship between the participants and me. It is important to acknowledge that I was not an "outsider researcher" but the teacher of the participants' upcoming course. As the knowledge produced in research interviews is constructed between the interviewer and the interviewee (Kvale \& Brinkman, 2009, p. 2), their relationship can have an impact on the interviewees' answers (Anyan, 2013; Karnieli-Miller, Strier, \& Pessach, 2009). The teacher-student relationship contains power asymmetry in favor of the teacher (Jamieson \& Thomas, 1974; Muller, 2001). To give an example, when I conducted the practitioner interviews in the development project in which children's data was collected (and in which I worked as an in-service teacher educator), several participants found it difficult to discuss the possible shortcomings of the project (Mertala, 2017). By remaining silent about their doubts, the participating teachers were "serving up" what they thought was wanted from them in order not to appear as challenging partners (see McCracken, 1988 , p. 27). In short, I was concerned that the students would hold back their 
critical views if the data were collected via interviews. I reasoned that the use of written assignments would allow the participants to express their views more freely than in research interviews.

In general, written assignments can be considered a good method for gathering rich data. It allows the writer produce the data when he or she has the right mindset for it. In addition, if the schedule for returning the texts is long enough (in this case, the participants had two weeks to provide the assignment), the writer has an opportunity to work with the text in a process-oriented manner which includes writing, reading, and re-writing phases. This enables the writers to reflect on what they want to say and how they want to present their case. Written assignments have been frequently used as research data in preservice teacher research. Mats Lindahl and Anne-Mari Folkesson (2012a, 2012b) used written assignments to explore preservice teachers' arguments for and against embedding computers in preschool practice. Beverly Funkhouser and Chrystalla Mouza (2013), in turn, analyzed preservice teachers' written assignments to investigate their initial beliefs and ideas regarding the role of technology in teaching and learning. In addition to technologyrelated topics, studies using written assignments have addressed themes such as preservice teachers' beliefs about children and childhood (Avgitidou, Pnevmatikos, \& Likomitrou, 2013).

In the present study, the preservice teachers were asked to write a free-form essay in which they discussed their views, beliefs, and attitudes regarding young children and technology as a pre-course assignment. The assignment was distributed via email before the first contact lesson, and the preservice teachers were informed that the aim of the writing task was to orient them to the course by having them reflect on their beliefs and attitudes toward ICT use in early childhood education. The task was not graded. In the instructions, the students were asked to write down what kinds of experiences they believe children have with ICT, and what the role of ICT should be in early childhood education. No examples of what was meant by ICT were given. A written permission to use the assignments as research data was sought after the course, as opposed to beforehand, to avoid influencing the content (de Oliveira Nascimento \& Knobel, 2017). This policy also made it possible for the students to get to know me better before deciding whether to give the permission or not. Fifty-seven students from three different classes participated in the course. Due to schedule-related issues, permission to use the assignments as research data was asked of students from only two classes, all of whom gave their permission. The data comprised 72 pages. 


\subsection{Data analysis}

In this chapter, I present the data analysis procedures. The data analysis was guided by the principles of qualitative research methodology which means that the quantitative methods used (i.e., counting frequency effect sizes; see Onwuegbuzie, 2003) were also based on and interpreted from the same epistemological and ontological foundations and frames as the qualitative analyses.

\subsubsection{Analysis of drawings: Monotype mixed analysis}

The children's drawings were analyzed via monotype mixed analysis (MMA). In MMA, the data - be it qualitative or quantitative - is analyzed by using qualitative and quantitative methods. The use of the method requires that the qualitative data is altered into a form that can be analyzed statistically and that quantitative data is transformed into a form that can be analyzed qualitatively (Onwuegbuzie et al., 2007). This mixing can be characterized as a combination of measurement and interpretation (Biesta 2010, p. 101) which allows rich and comprehensive views to be constructed of the phenomena under investigation (Puntambekar, 2013). Although traditional mixed-methods research has been criticized for valuing the quantitative part over the qualitative part (Creswell, 2011; Ellingson, 2011), in MMA the research questions and the primary nature of the data determine the order of the analysis process and the way the research is reported. If the research aim is interpretative and the data is qualitative, then qualitative analysis is the one to begin with and the one that has the leading role in the report (Onwuegbuzie et al., 2007).

In the context of the present study, the initial research interest was to explore how first space and second space cultures are reflected in children's ideas regarding the use of ICT in early childhood education (i.e., how media cultural aspects and the pedagogical practices of early childhood education are reflected in children's ideas). Thus, the fundamental research interest can be articulated to be interpretative. Similarly, the data used in Article I (drawings and interviews) is commonly described as qualitative (Biesta, 2010; Patton, 2002). Following the principles of qualitative research methodology, children's drawings (and interviews) were not believed to provide straightforward and unambiguous information about children's experiences (see Dyson, 2003) but to reflect the broader (digital) media cultural sphere in which the children live. For instance, references to certain digital games, movies, or programs are not straightforwardly assumed to signal that children have played these games or watched these programs. They are considered 
forms of digital culture in which the children are interested and which are considered good and cool among the children's peers (Aarsand, 2010; Lehtikangas \& Mulari, 2016; Salomaa \& Mertala, in press). Stated differently, children's ideas were not thought to necessarily draw from actual first-hand experiences but from children's observations, as well as their values and tastes regarding ICT use.

In the present study, transforming the data meant quantifying the occurrence of how often different activities, devices, and (digital) media cultural references were drawn and mentioned (Selwyn et al., 2009). The purpose was to achieve an overall picture of which activities and devices, as well as first and second space related themes, were the most frequently drawn and mentioned among the whole population of participants. These frequency counts were then converted to percentages to calculate the frequency effect size (Onwuegbuzie, 2003). The interpretative analysis was carried out to examine the holistic impression of the drawings by attempting to locate the cultural aspects reflected in the drawings (Anning \& Ring, 2004; see also Selwyn et al., 2009). The second objective of the interpretative analysis was to capture the diversity of the data by providing a space for ideas from individual children.

\subsubsection{Analysis of the written assignments: Constant comparative analysis}

An abductive approach was used as the guiding principle of data analysis in Articles II and III. The theoretical thread in Article II was the representations of the "child computer user" (Selwyn, 2003), and the (mainly negative) representations of parenthood identified in existing literature (e.g., Alliance for Childhood, 2004; Baum \& McMurray-Schwarz, 2004; Meehan \& Meehan, 2017). In Article III, the main theoretical thread was the different frames - teaching, education, and carethat provide different orientations for early childhood education (e.g., Broström, 2006; Einarsdóttir, 2003; Salomaa, 2016).

In abductive analysis, the researcher moves between inductive and deductive reasoning while practicing the constant comparative analysis method (CCAM; Suddaby, 2006). The CCAM is often considered synonymous with grounded theory research (Fram, 2013). However, Mary O'Connor, Ellen Netting, and Lori Thomas. (2008, p. 41) argued that "constant comparison, the data analysis method, does not in and of itself constitute a grounded theory design." In other words, the CCAM can be considered "a set of procedures and techniques for gathering and analyzing the data" (Strauss \& Corbin, 1998, 3), without aiming to constitute a substantive 
theory, which is the aim in grounded theory research (O'Connor et al., 2008). This approach allows researchers to take a pragmatic stance toward the CCAM. The research questions asked (Fram, 2013) and the kind of material involved (Boeije, 2002) determine the number of steps taken and the types of comparisons performed during the analysis process.

\section{Analysis for Article II}

The analysis process consisted of three phases. The first phase concentrated on beliefs about children, the second on beliefs about parents, and the third on the relationship between these beliefs and participants' views of how ICT should or should not be used in early childhood education. The three phases were conjoined rather than being completely separate. As beliefs about children were understood to be intertwined with beliefs about parents and vice versa, the categories of children constructed during the first phase were not understood to be necessarily the final ones but a subject to evolve when these representations were compared with those about parents (see Corbin \& Strauss, 1990).

Initially, I went through all the data and sought references to beliefs about children's experiences with ICT at home. I then categorized the extracts by using Neil Selwyn's (2003) representations of "child the computer user" as a guiding framework. At this point, I replaced the term "computer" with the term "technology," which better captured the diversity of the technologies represented in the essays. Following the first phase, I had three preliminary categories of representations of children:

- the naturally competent child technology user,

- the victimized child technology user, and

- the needy child technology user.

In the second phase, I examined what kinds of representations of parents and parenting were connected to the representations of children. During this readthrough, I also noticed how several students wrote that parents' own technology use can be harmful for children. As in these cases, children were represented as victims but not as technology users, I omitted the words "technology user" from the representation categories of children. In conclusion, I identified three categories of child-parent representations through the first two analysis phases:

- the naturally competent children of invisible parents, 
- the victimized children of victimizing parents, and

- the needy children of disadvantaged parents.

In the third phase, I again went through all the data to examine the relationships between preservice teachers' beliefs about children, parents, and technology and the teachers' views about the role of technology in early childhood education.

\section{Analysis for Article III}

In this study, the constant comparison process consisted of three phases and took place at three levels (Boeije, 2002):

- comparison of the theory and data,

- comparison within data, and

- comparison of the data and theory.

Initially, I went through all the data, focusing on material that discussed why and how technology should or should not be used in early childhood education. Then I scrutinized these extracts through the analytical framework of teaching, education, and care. My main interest when carrying out the analysis was not only what the participants were writing about but also from what perspective they were writing (see also Puroila, 2002). I gave special attention to the question, who are the children the participants are writing about (i.e., how old are they, what are their developmental needs, and do they have access to technology at home)? With this analytical query, I aimed to identify how participants' perceptions of children relate to the frame through which they approach technology integration. In other words, the objective was to identify for whom the technology integration was thought to be beneficial and for whom it was not, and to establish how these perceptions are related to teaching, education, and care. I also identified any personal experiences linked to these views, to establish if and how they shape preservice teachers' beliefs about ICT integration. In other words, I further compared the technology-related extracts I had highlighted and scrutinized in the first phase to the whole data from each participant, and I compared interpretations based on the data from individual participants with each other to identify (possible) patterns in the whole data set (comparison within data). Last, to better identify how participants' beliefs relate to early childhood education traditions, as well as to the broader discourses promoting or opposing ICT integration, I compared the data-driven interpretations to theoretical literature (comparison of data and theory). 


\section{Overview of the articles}

The empirical body of this dissertation constitutes three articles all of which I was the sole author. Table 3 summarizes the topics of each article, and in the following overview, I offer a brief introduction of each article.

Table 3. Focus of the articles.

\begin{tabular}{ll}
\hline Article & The main topic \\
\hline I & How are informal ICT cultures and pedagogical cultures of early childhood education reflected \\
& in children's ideas for ICT use in early childhood education? \\
II & Preservice teachers' beliefs about children and ICT at home \\
III & Preservice teachers' beliefs about the essence of early childhood education and the role of \\
& ICT in it \\
\hline
\end{tabular}

\subsection{Article I: Fun and games: Finnish children's ideas for the use of digital media in preschool}

In this study, I analyzed drawings from and interviews with 5- to 6-year-old children $(\mathrm{N}=103)$ to explore their ideas for the use of ICT in early childhood education. As the participating groups had no (or only a little) existing ICT, the term "idea" refers to "what if" questions and the children's thoughts about the future use of ICT. The second research interest was to examine how different contextual and cultural aspects (including, but not restricted to, the children's experiences with ICT at home) were reflected in the children's ideas. I analyzed the data with monotype mixed analysis (Onwuegbuzie et al., 2007).

Only a small number of children linked ICT use in existing preschool practices, that is, using ICT for learning purposes or for documenting their doings in preschool. More common were ideas in which children exported informal digital practices - that is, playing digital games or watching movies - to the preschool context. The children's ideas included a notable number of (digital) media cultural references. For example, the games the children referred to were mainly commercial entertainment games. 


\subsection{Article II: Wonder children and victimizing parents: Preservice early childhood teachers' beliefs about children and technology at home}

In this study, I examined written assignments completed by preservice early childhood teachers $(\mathrm{N}=38)$ via the constant comparative analysis method (Corbin \& Strauss, 1990; Fram, 2013; Suddaby, 2006) to find answers to three research questions:

- What beliefs do preservice teachers have about children and technology at home?

- How are parents represented in preservice teachers' beliefs about children and technology?

- What are the relationships between these beliefs and preservice teachers' views on the role of technology in early childhood education?

The preservice early childhood teachers believed children were born-competent technology users who need no help or tutoring from parents to become skillful ICT users. These preservice teachers believed that parents, in turn, lacked the skills or will needed to regulate their children's technology use which, again, the teachers often described as excessive and caused children health problems, as well as impaired their imagination and social skills. The preservice teachers expressed that early childhood education was responsible for ensuring that play and social interaction are still included in young children's lives.

\subsection{Article III: Digital technologies in early childhood education: A frame analysis of preservice teachers' perceptions}

This study had two aims: The first was to contribute to the theoretical grounding of early childhood ICT integration research, and the second was to explore the kinds of perceptions preservice teachers hold in relation to technology integration when they start their initial training. I addressed the first objective by exploring the possibilities of frame analysis theory (Goffman, 1974) in understanding preservice teachers' perceptions of the role of digital technologies in early childhood education through the frames of teaching, education, and care. The second, in turn, was achieved by including first-year preservice teachers as participants. The overarching research question was: How do preservice teachers' perceptions of 
technology integration relate to early childhood education's threefold task of teaching, education, and care?

The findings suggest that an individual preservice teacher can be for or against technology use depending on the frame the teacher reflects on technology integration. Children's ages and participants' beliefs about children's access to technology at home were the most significant factors in the variation in the dynamics between and within the frames. 


\section{Results: Mapping the third space of ICT integration in early childhood education}

In the results chapter, I re-contextualize and re-conceptualize the findings of the empirical studies through the third space theory. The main results of this dissertation study are presented in three subchapters. The first subchapter concentrates on how first and second spaces were reflected and conceptualized in children's drawings and interviews. Thus, the first subchapter concentrates on the findings provided in Article I. The second subchapter describes how first and second spaces were reflected and conceptualized in preservice teachers' beliefs. This subchapter concentrates on the findings provided by Articles II and III. The third subchapter is a discussion in which these findings are brought into dialogue. Figure 4 presents how the individual articles are located in the overarching frame of the third space.

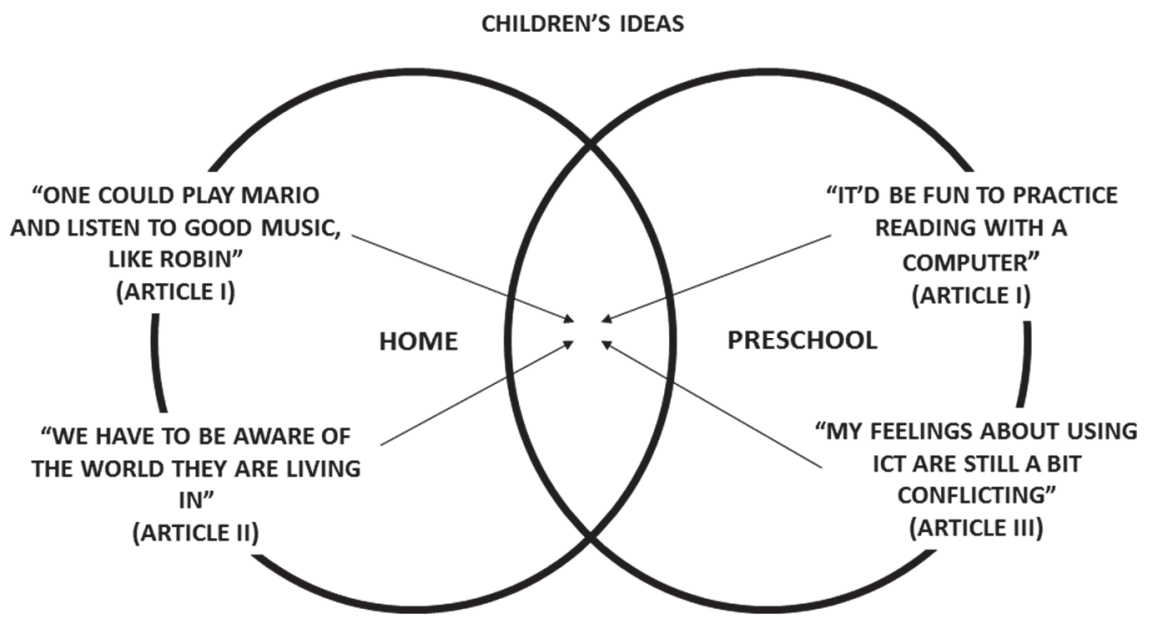

PRESERVICE TEACHERS BELIEFS

Fig. 4. Location of empirical articles in third space framework.

\subsection{First and second spaces in children's ideas}

The distribution of different activities and devices in children's drawings is presented in Table 4. The left side of the table deals with the activities. For example, 
gaming was mentioned by 86 individual children ( $83 \%$ of the participants); 38 were girls and 48 were boys, corresponding to $78 \%$ of the girls and $89 \%$ of the boys participating in the study, respectively. At the far right of the table, the number of times different activities were mentioned in total is presented. In the case of gaming, the number was 119 , which is higher than the number of children, as several children expressed that they would like to use several devices for playing games. The presentation of devices follows the same logic: 73 children mentioned computers ( $71 \%$ of the participants); 39 were girls and 34 boys, totaling $80 \%$ of the girls and $63 \%$ of the boys, respectively. I begin by exploring the (digital) media cultural sphere (the first space). Then, I discuss children's conception of ICTmediated early childhood education (the second space). 


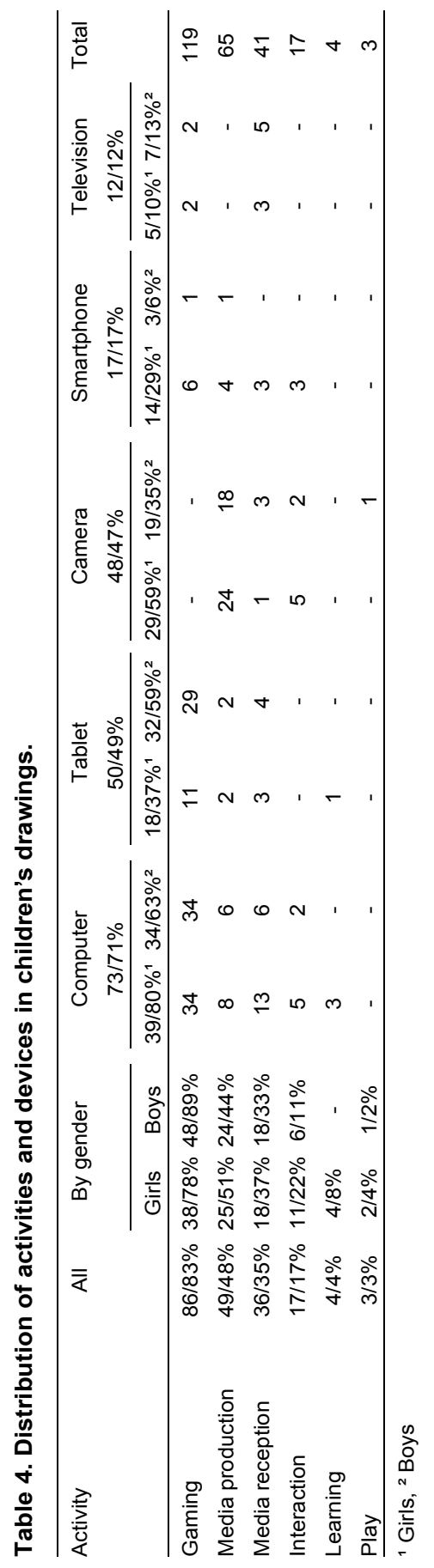




\subsection{1 "One could play Mario and listen to good music, like Robin"}

Comments related to the commercial media culture (the first space) were notable in the children's data. As playing digital games and media consumption (including watching movies and listening to music) have become popular and regular activities among young children in Western contexts (Chaudron et al., 2015), the popularity of these activities was by no means a surprise. Gaming and media consumption were not portrayed as generic activities: The games the children referred to were - to a great extent - commercial entertainment games. In 34 cases, the games were explicitly identified. Angry Birds, which at the time of the data collection was the digital game most frequently played by Finnish children (Suoninen, 2014), was mentioned the most often. Other games mentioned by the children included Minecraft, Super Mario, and Pou. Similarly, the movies and programs (e.g., Cars 2) the children wanted to watch, as well as the music (e.g., Robin) they wanted to listen to, were those at the peak of popularity at the time of the study.

In addition to recognizable commercial games, there were a notable number of references to "monster games," "racing/car games," and "princess games that are most likely commercial games but could not be linked unambiguously to any specific product. With these indicative references included, different brands ${ }^{19}$ were found in a total of $65 \%(n=67)$ of the drawings. Media cultural influences were especially notable in boys' drawings as $78 \%(\mathrm{n}=42)$ included explicit or implicit brands in their drawings. Similarly, boys were keen about playing games, and almost half of the boys $(44 \%, n=26)$ expressed interest only in games. This could be because playing digital games is more common among young boys than among young girls (Aarsand, 2010). All this data supports Buckingham's (2015) statement about ICT being a cultural form for children.

The overall percent of brand references was higher than in Selwyn et al. (2009) study (24\%). One possible explanation for this difference is related to recent changes in (digital) media culture. There was a six-year interval (2007-2013) between the data collection in Selwyn et al. (2009) study and Article I. During these years, handheld technologies, especially tablet computers, have become a typical form of household ICT (Chaudron et al., 2015; Marsh et al., 2015), and at the time

\footnotetext{
${ }^{19}$ The definition of a brand is loosely understood here as a trademark or the name of a product, or content with no requirement to be especially well or widely known.
} 
of the data collection for Article I, iPad sales were breaking records in Finland (Apple, 2013). Tablet computers were not only the second most often mentioned device ( $49 \%, \mathrm{n}=50)$, but among the 25 brands named by the children, the iPad was mentioned the most often (12 references). The findings of a study by Dunn et al. $(2016,6)$ suggested that children use iPads as a collective category for all tablet computers as children who were not aware of which brand their tablet was referred to them as "kinda like an iPad" Interestingly, one child understood a tablet as being a pill and drew a container full of tablets. This misconception could be caused by the practice in Finnish early childhood classes of giving children xylitol tablets after lunch. Although the example is anecdotal, it emphasizes the importance of not of thinking of children as a homogenous group regarding their knowledge of and experience with ICT acquired in the first space.

\subsection{2 "It'd be fun to practice reading with a computer"}

In contrast to the richness of the (digital) media cultural first space references, only a small number of drawings contained examples of contextualized ICT-mediated practices in which ICT use was connected to the traditions of early childhood education. Some children remarked that they would like to take pictures and videos to document their doings in preschool, and one child drew himself playing with a computer during the free play period. In addition, only $4 \%(n=4)$ of the children expressed that they would like to use ICT for learning in preschool. One child commented that she would like to practice reading with a computer. Two other children, in turn, stated that they would like to do calculations with a computer, and one commented that she would like to find information on train schedules and ticket prices. One possible explanation for the low number of learning-related references is that children do not consider preschool a place for learning: In Stig Broström's (2016) study of 10-year-old children's memories about preschool, none of the 251 children came up with memories they would have linked to learning. Instead, play, games, and fun were the most common things the children remembered ${ }^{20}$ Another explanation is that children do not consider ICT a tool for learning in early childhood education. This finding could be due to the lack of such experiences as

\footnotetext{
${ }^{20} \mathrm{I}$ am not suggesting that children would not learn via play or games or that play and games could not be used as pedagogical methods to teach children about things. What I mean is that the children in Broström's (2016) study simply did not connect these activities with learning or mention learning. This is supported by Einarsdóttir (2014) as in her study many of the children did have difficulties explaining what they learned from the preschool teachers
} 
only one of the five groups who participated in this dissertation study had functioning ICT for children to use at the time of the data collection.

Although the shortage of first-hand experiences could be one reason for the lack of contextualized practices in drawings, it is not the whole story. None of the children from the group who had a functioning interactive whiteboard (IWB) drew or mentioned the IWB. One explanation is that the children saw no reason to draw IWBs, as they already had them. However, it is possible that children were not satisfied with an IWB as a form of ICT or with the practices carried out with it. Practitioners of this group reported that the IWBs tended to freeze every time two children touched it simultaneously (Mertala, 2017). Children have also evaluated IWB-mediated practices as low in playfulness (Morgan, 2010).

The lack of experience could also be a reason for the finding that no children drew or mentioned teachers. However, as the absence of teachers was also notable in the study by Selwyn et al. (2009) in which the children had experiences of using ICT at school, this phenomenon deserves closer inspection. Although no comprehensive clarification for this can be obtained from the data, there are two different (but not mutually exclusive) explanations: The first explanation is that the drawings (implicitly) reflect children's wishes to be the ones in control of the devices. This reasoning is supported by Selwyn et al. (2009) as in their study children explicitly called for broader agency with the devices in school. The second explanation is related to the relationships of ICT-mediated activities and children's understanding of teachers' roles in early childhood education. According to Rönn Palmadóttir and Johanna Einarsdóttir (2015), young children understand teachers as those who assist the children in play situations and with play materials and who participate in play, give confirmation for children's competencies, and support social interactions (see also Broström, 2016). As the children only rarely discussed ICT use in terms of play $(4 \%, n=3)$ and social interaction $(17 \%, n=17)$, this could be a reason for the absence of teachers.

\subsection{First and second spaces in preservice teachers' beliefs}

This chapter presents the key findings related to preservice teachers' beliefs about children's first space (see Subchapter 7.2.1 and Article II) and beliefs about the role of ICT in early childhood education (see Subchapter 7.2.2 and Article III). 


\subsection{1 "We have to be aware of the world they are living in"}

Preservice teachers acknowledged the importance of teachers being aware of children's experiences with ICT at home. Families were not portrayed as a homogenous group as the participants noted that families differed in terms of financial situation, cultural and religious backgrounds, and parental educational values and competencies. This supports Baum's (2000) claim that preservice teachers are aware that the families they will work with come from diverse backgrounds.

\section{The needy children of disadvantaged parents}

ICT was believed to have a significant role in young children's everyday lives whether they had access to it or not. Those with no access were considered disadvantaged as learning to use ICT was understood to be crucial for children's future schooling and work life. The preservice teachers acknowledged that families' financial situations can cause differences regarding the availability of digital resources, and thus discriminate against children who come from less fortunate socioeconomic backgrounds. One preservice teacher, for example, wrote how poorer families have to prioritize their purchases, and thus, the families may have to choose between buying their child a warm winter uniform and buying their child a smartphone. Placing a warm winter uniform (which, in the Finnish climate, is essential) and a smartphone in the same category suggests that access to modern technology was understood as being essential to a child's future life. Furthermore, it also suggests that if the family's financial situation were better, they would buy their children the same technology the children from more fortunate families were believed to have access to.

\section{Wonder children of invisible parents}

Although families were not portrayed as a homogenous group, the preservice teachers believed the majority of children lived in technology-rich homes. The preservice teachers believed that children with access to ICT were self-taught and savvy technology users and referred to them as the "wonder children of future technology" which piquantly captures the kind of magical and mythical aura included in descriptions of children's presumed ICT competencies. ICT skills were something children were believed to learn with no help from their parents (see also 
Plowman, McPake, \& Stephen, 2008), and children were also believed to master digital technologies better than adults. These discourses have much in common with Mark Prensky's (2001, p. 2) description of digital natives, who are "surrounded by and using computers, videogames, digital music players, video cams, cell phones, and all the other toys and tools of the digital age" and thus are "native speakers' of the digital language of computers, video games and the internet." Such beliefs have been identified among preservice (Lindahl \& Folkesson, 2012a) and in-service teachers (Roberts-Holmes, 2014; Salomaa \& Mertala, in press).

\section{Victimized children of victimizing parents}

Although preservice teachers believed children's access to ICT use taught them functional ICT competences (i.e., how to use a computer), at the same time, they feared access hindered other skills. Several teacher students expressed their concerns about technology use stealing time from other activities, that is, play and social interaction. Replacing those activities with technology use was thought to have several downsides. Participants believed that technology use hinders children's social skills, as they believed children play games and watch movies and children's programs alone. In addition, participants expressed their concern that technology use can be harmful for children's physical health. Obesity, eye fatigue, hyperactivity, and attention deficit disorder were some of the concrete examples given.

As the preservice teachers were writing about the youngest children, they emphasized that parents are responsible for ensuring that children are not exposed to harmful content or use the technology for prolonged periods. In the essays, the preservice teachers stated that the disadvantages listed above could be avoided if parents were aware of them, if they supervised and regulated their children's technology use, and if they made sure their children's on- and off-screen activities were appropriately balanced. However, this was something parents were believed to have trouble with, and students often referred to children's high technology use as being a consequence of incompetent parenting (see also Lehtikangas \& Mulari, 2016; Meehan \& Meehan, 2017; Ylönen, 2012). The preservice teachers thought parents lack the skills or the will needed to regulate their children's technology use. A consistent theme was that parents do not want to regulate children's technology use because by letting children play games or watch programs for prolonged periods, parents can make things easier for themselves. 
It was also believed that parents' own technology use takes time away from their children, and several essays portrayed parents as being unable to control their own technology use (Flewitt et al., 2015). In these representations, technology, especially smartphones, was represented as "sticky media devices" (Mantere \& Raudaskoski, 2017), which refers to a situation in which a child tries to gain attention from a parent who is immersed in smartphone use. Parents' antisocial technology use was also believed to teach children similar behavioral models.

\subsection{2 "My feelings about using ICT are still a bit conflicted"}

The findings of this study suggest that preservice teachers' orientations toward ICT use in early childhood education are a highly complex issue as the participants articulated numerous different arguments for and against integration of ICT in early childhood education. Conclusively, positive beliefs were linked mostly to teaching, while care was discussed almost solely from the perspective of negative effects. ${ }^{21}$ ICT's role in the educational task of early childhood education was believed to be twofold: The preservice teachers saw early childhood education either as preparation for the societal change or as a place where traditional activities are preserved.

Variations in beliefs were observed not only between the participants but within an individual preservice teacher, who can have varied and sometimes competing and contradictory beliefs regarding ICT use, depending on the perspective (teaching, education, or care) through which he or she reflected on the topic. Grounded on Ervin Goffman's (1974) seminal work on frame analysis, Puroila (2002, p. 45) argued that "talking about one single professional role or identity is misleading, as educators have different roles and identities within different frames." The findings of this dissertation study support her statement, as the preservice teachers moved between different roles in their narratives.

\footnotetext{
${ }^{21}$ Only one student expressed that ICT could have something to add for the care task of early childhood education. She wrote that "children's naptime could be enforced by using a developed sound system". I understand this to mean that with a good sound system, some comforting music (or other calming soundscapes) could be played to children during naptime to make the situation more relaxed and enjoyable.
} 


\section{Age matters: Tensions between teaching and care}

The findings of this study suggest that children's age plays a notable role in the dynamics between different orientations. This was especially the case with preservice teachers' beliefs related to teaching and care. Several participants explicitly stated that ICT use relates to teaching and thus, preferred ICT use with children in pre-primary education (6 year olds) than with younger children. This notion can be partially explained by the fact that pre-primary education-as the transitional year from early childhood education to primary education - is often considered school preparation by many preservice and in-service teachers (Einarsdóttir, 2003; Lindahl \& Folkesson, 2012a; Ylitapio-Mäntylä, 2009). Similar viewpoints were expressed by the preservice teachers in this study.

Moreover, when the participants were writing about children aged 3 and younger, they approached early childhood education from a profoundly careoriented perspective. This is supported by Ylitapio-Mäntylä (2009) as in her study she found that teachers working with the youngest children orient toward their work from a profoundly care-related angle. As argued by Katerine Van Laere and Michel Vandenbroeck (2018), care is often considered work related to the physical needs of children while teaching is work related to their cognitive needs. In the data, younger children's developmental needs and ways of being were expressed in a more physical way than those of pre-primary-aged children (see also Lindahl \& Folkesson, 2012a). This notion provides another perspective for looking at preservice teachers' beliefs that teaching with ICT is not suitable for the youngest children. It appears that it is not merely ICT use that the children are seen to be "too young for," but they are also "too young" to be taught in general. Although teacherinitiated practices can be carried out with older children, with the youngest children, the role of the teacher is to ensure that children's "natural" learning and development processes are not disrupted by unnecessary things, such as ICT use.

\section{Beware the positive: Digital games and playful learning}

Previous research has identified that preservice and in-service teachers have a positive attitude toward ICT as a tool for teaching (e.g., Brown \& Englehardt, 2017; Ramírez et al., 2017). The findings of the present study support this notion as the vast majority (32 out of 38) of preservice teachers expressed positive beliefs regarding the benefits of using ICT in teaching. Nevertheless, having positive beliefs was not the same as having pedagogically sound beliefs. This conclusion 
was most apparent in participants' beliefs regarding game-based learning which here refers to the use of digital games in teaching.

Participants who promoted game-based learning equated game-based learning with play-based learning as the use of digital learning games that was often described with terms such as "fun" and "playful." The preservice teachers also explicitly expressed that one of the key elements of the use of digital games is that children do not notice that while they are playing games they are learning at the same time. The surreptitious nature of game-based learning can also be linked to play-based learning, as it corresponds well with the idea that "even though children learn while playing, they don't play to learn" (Sintonen, Ohls, Kumpulainen, \& Lipponen, 2015, p. 8), a commonly used expression in the Finnish context. As play is a central aspect of early childhood education in Finland (Opetushallitus, 2016), as well as globally (Pyle, DeLuca, \& Danniels, 2017), by using this assimilative reasoning, preservice teachers were able to legitimate the use of technology by embedding it in the established discourses and traditions of early childhood education. As suggested by Lindahl and Folkesson (2012a), by emphasizing informal learning and playfulness preservice teachers can make the use of technology appear less threatening to early childhood education traditions. According to previous research, combining play-based pedagogy and digital technologies has appeared to be challenging for early childhood teachers (Edwards, 2016; Nuttall et al., 2015; Palaiologou, 2016b).

However, this assimilative logic is simplistic and pedagogically awkward. First, the phrase "children don't play to learn" refers to free play: a child-initiated activity with no goals set by the teachers. The use of instructional games, in turn, is a teacher-initiated practice with explicit educational goals. In general, the view of children as passive learners who are unaware of the purpose of their activities is highly problematic. Research suggests that encouraging children to think about what they are doing and why they are doing it makes learning activities more goaloriented from the children's perspective, and thus more conscious (Sandberg et al., 2017). This view is also at odds with the guidelines set out in the Finnish National Core Curricula, as in the curricula the development of learning skills is named as one of the key tasks of early childhood education (Opetushallitus, 2016). In short, having positive beliefs about technology integration does not necessarily mean that technology will be used in a pedagogically appropriate manner. 


\section{To prepare and to preserve: The twofold educational task of early childhood education}

Almost all of the preservice teachers referred to the technologization and digitalization of contemporary society in their essays (see also Izumi-Taylor et al., 2010; Lindahl \& Folkesson, 2012a, 2012b), but the views of how early childhood education should react to this societal change varied. In some essays, the preservice teachers emphasized that early childhood education should prepare children for a highly digitalized society (preparation), while in others, they noted that a key task of early childhood education is to ensure that traditional activities remain a part of young children's lives (preservation). Some essays included both viewpoints. What was missing was the reformative nature of education as all the examples and reasoning in the preparation discourse were about equipping children to function effectively in society rather than to act as agents of change in their own turn (Biesta et al., 2015).

Regardless the educational frame through which the preservice teachers interpreted ICT integration, they understood early childhood education to have an important role in giving all children equal opportunities for future schooling, as well as life in general. One way to achieve this goal was by bridging the digital gap between children from different socioeconomic backgrounds. As discussed in Subchapter 7.2.1, children from economically disadvantaged families were not thought to have access to ICT, and thus, these children were believed to have worse starting points for life than their more fortunate peers.

In contrast, some of the children who had access to ICT were believed not to get their share of traditional play, social interactions, and outdoor activities at home. These activities are also core aspects of early childhood education (Broström et al., 2015; Opetushallitus, 2016; Pyle et al., 2017). Many preservice teachers wrote that preschool should be a place where children have opportunities to engage in imaginative roleplay and social interaction, which they did not believe were regular aspects in children's home lives. Some even stated that early childhood education should offer children an alternative and technology-free environment (see also Friedrichs-Liesenkötter, 2015; Lehtikangas \& Mulari, 2016).

In summary, be it access to or a respite from ICT, early childhood education's educational task was understood to be taking care of the things parents were believed to fail to deliver. That being said, another prominent theme was that teachers in early childhood education should educate not only children but also their parents about how to use technology in a manner that does not jeopardize 
children's well-being. This notion not only supports Ylönen's (2012) argument that teachers often assume parents allow their children to use too much and the wrong kind of technology but also mirrors the culture of Finnish early childhood teachers acting as educational experts who give advice to parents in parent-teacher meetings (Alasuutari, 2010; Hujala, Turja, Gaspar, Veisson, \& Waniganayake, 2009), as well as the finding that preservice teachers tend to think that their knowledge of children is more relevant that of parents (Graue, 2005).

\subsection{Discussion of the results}

The overarching research question of this dissertation study was what are the key characteristics of the third space of ICT integration in early childhood education when this space is constructed from children's ideas and preservice teachers'beliefs? In this Discussion subchapter, I discuss three themes that-based on the synthesis of Articles I, II, and III-I consider to be the most important in shaping the third space and thus the most crucial ones regarding ICT integration (see Figure 5).

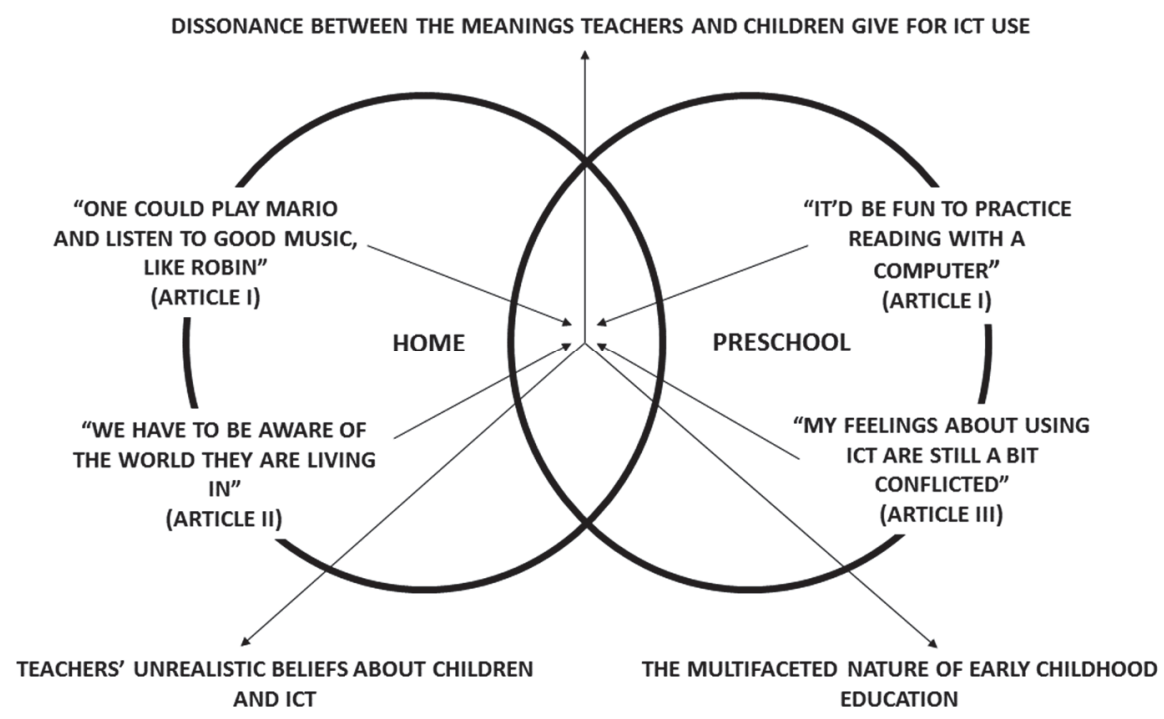

Fig. 5. Main themes arising from the synthesis of the articles. 


\subsubsection{Dissonance between the meanings children and teachers give to ICT use shaping the third space}

The first of the three key points is that there is a dissonance between the meanings teachers and children give to ICT use, and this dissonance shapes the third space. I dig deeper into this question by looking at it from the viewpoint of digital games. $86 \%$ of the children in this study reported that playing digital games is what they would like to do with ICT in preschool. Similarly, the preservice teachers commented that digital learning games are a good method for integrating ICT into early childhood education. Superficially, it appears that all is well: Children want to play games, and teachers respond to this desire with (age-appropriate) gaming. However, for the teachers, playing digital games in early childhood education means using educational games to teach children different curricular subjects, predominantly literacy and math (see also Blackwell et al., 2016; Mertala, 2017). In contrast, children commented explicitly that what they would like to play in preschool are their favorite (commercial and leisure) games. Teachers, in turn, consider playing commercial games something children should be protected from and which have no role in early childhood education (see also Lehtikangas \& Mulari, 2016).

In short, there appears to be a dissonance between the meanings that children and teachers give to digital games. Thus, using digital learning games cannot be automatically considered child-initiated pedagogy (cf. Dunn et al., 2016). It is questionable whether merely digitalizing early childhood education would make it "a contemporary professional practice of relevance" (Hernwall, 2016), if it pays no attention to ICT as a cultural form (Buckingham, 2015; Potter \& McDougall, 2017). Instead of being initiated by children, such practices can be described as a collision of teacher-initiated goals and practices and children's digital media cultural experiences and interests. Subtle empirical evidence suggests that children do not consider playing instructional games in preschool a learning activity (Kjällander \& Moinian, 2014; Vangsnes et al., 2012). Thus, teachers' high hopes for the effectiveness of game-based learning are overestimated, as well as pedagogically problematic.

ICT pedagogy that pays no attention to children's media cultural dispositionsand topics of interest in general-is also at odds with Finnish early childhood curricula as they emphasize the importance of paying attention to children's experiences and views (Opetushallitus, 2016). This alignment unambiguously demands that children's views and ideas need to be considered and recognized in 
pedagogical planning. One child expressed that she would like to use the internet to study train schedules and ticket prices. Although such an idea may seem an anecdotal example, it is a fruitful and concrete starting point for examining different digital services and their role in our everyday actions. That being said, not only media cultural interests matter: The second most popular activity, media production, included many examples of children wishing they could take pictures of their doings in preschool. These themes and other pedagogical possibilities are discussed in subchapter 8.2.2: Implications for pedagogical practice.

\subsubsection{Teachers' unrealistic beliefs about children and ICT shaping the third space}

The second key theme can be compressed into the statement that teachers have unrealistic beliefs about children and ICT. Children were often presented as born competent ICT users who outshine their parents and teachers with their skills. In the second one, children are portrayed as victims of excessive ICT use and bad parenting. The belief that children are digital natives is shared by parents (Plowman et al., 2008) and preservice and in-service teachers (Lindahl \& Folkesson, 2012b; Salomaa \& Mertala, in press; Roberts-Holmes, 2014) but is challenged by empirical research. In the large-scale European Union (EU) Kids Online report (Livingstone, Haddon, Görzig, \& Ólafsson, 2011), two-thirds of 9- to 10-year-old children commented that they did not know the internet better than their parents. In addition, not all children in the present study knew what a tablet computer was. According to Sonya Livingstone et al. (2011, p. 46; see also Kirschner \& De Bruyckere, 2017), the danger of the talk about digital natives is that it obscures children's need for support in developing digital skills. The preservice teachers in the present study found it difficult to think what they could teach about ICT for those children who have access to ICT at home.

However, the preservice teachers believed that children with access to ICT used it excessively. The preservice teachers believed this excessive use leads deprivation of traditional play, social interactions, and outdoor activities. This was understood to be due to incompetent parenting. How realistic these beliefs are is another important question. This is especially the case with the "victimizing parents" discourse as preservice teachers expressed highly discriminatory views on contemporary parenthood through it. When preservice teachers' beliefs are compared with findings of research on children ICT at home, the outcome is that the fears are overemphasized. To give an example, teachers believed that children's 
ICT use was a solitary activity. However, in Stephanie Chaudron and colleagues' (2015) cross-national study, Finland stood out as the country with most social ICT use. This finding is supported by the findings of the Children's Media Barometer (Suoninen, 2014) as according to it in every age group between age 0 to 6 years children's ICT use took place more commonly with someone (with parents or other children) than alone. The same result was found for the amount of ICT use. For example, Ruslan Slutsky and Lori DeShetler (2017) reported 3- to 5-year-old children to spent 5.76 hours engaging in non-technology play (indoors or outdoors) and 2.62 hours of technology play during the weekend. During the weekdays, the numbers were 3.15 hours for non-technology play and 1.91 hours for technology play. Furthermore, parents have acknowledged that children's ICT use includes risks (Palaiologou, 2017). Thus, regulating and monitoring children's ICT use is understood to be good parenting, and guardians have reported that they feel guilty if they let their children use technology for a prolonged period (Aarsand, 2011; Noppari, 2014). In other words, a technology-rich context does not lead automatically to high use by children, and although digital technology is an important part of children's lives, it does not dominate them.

The same also applies to the preservice teachers' beliefs about disadvantaged parents. The idea that the "digital gap" is a static condition of absolute inequalities between two distinct groups (van Dijk, 2006) is simplistic. Although family income appears to affect families' opportunities to have an internet connection and technology (e.g., Eurostat, 2014; Rideout \& Katz, 2016), due to the proliferation of affordable technology, such as smart phones and tablet computers, as well as inexpensive wireless internet connections, the digital gap is narrowing all the time. The number of low-income families with 0 - to 8 -year-old children who have a mobile device increased from 34\% to 51\% between 2011 and 2017 in the United States (Common Sense Media, 2017). Additionally, in a recent British report (Marsh et al., 2015), there were no notable family income-based differences in terms of whether children could access tablet computers. The only difference was that children from higher-income families had access to more expensive tablets (e.g., iPads) and those from lower-income families to less expensive ones (e.g., Samsung Galaxy).

Although the data does not provide a full account of how these beliefs are constructed, there are three different, but not mutually exclusive, explanations: First, some preservice teachers referred to personal experiences and observations gained, for instance, while doing child care work in families. Research suggests that people, in general, assimilate new information based on their existing beliefs, which, again, 
can be formed by chance and anecdotal observations and are rarely evaluated critically (Ertmer, 2005; Nespor, 1987). The aggravated perceptions regarding the quality of children's upbringing at home can also reflect the history and tradition of Finnish early childhood education and media education policies. In Finnish media education policy documents, parents are often represented as incapable educators regarding digital media and that institutional education is responsible for guiding and supporting parents in this demanding task (Uusitalo, 2015). Parents' need for support of and guidance by welfare experts is also a central theme in (previous) Finnish early childhood education curricular documents (Onnismaa, 2010). Third, it is also common that children are portrayed as either digital natives or victims of technology in the media (Plowman, McPake, \& Stephen, 2010; Selwyn, 2003; Wartella, Rideout, Lauricella, \& Connell, 2014).

\subsubsection{The multifaceted nature of early childhood education shapes the third space}

The third key point can be summarized in the statement that the multifaceted nature of early childhood education shapes the third space. Especially in the Nordic context, early childhood education is understood as a combination of teaching, education, and care, known as the EDUCARE framework (Broström, 2006; Van Laere \& Vandenbroeck, 2018). Although EDUCARE has been described as a holistic framework (Opetushallitus, 2016), the findings of this dissertation study suggest that in ICT integration the framework acts as a disintegrating vehicle. The teaching perspective on ICT integration was mainly positive. However, when the perspective changed to care, the views were profoundly negative.

These contradictions took place at two levels: between and within the participating preservice teachers. It is important to acknowledge the differences between the views of different teachers because in many countries early childhood education is carried out in teams (Van Laere, Peeters, \& Vandenbroeck, 2012). If educators ${ }^{22}$ working in the same group have different perspectives on ICT integration, these inconsistencies create different kinds of micro-spaces for children to encounter (see also Marsh, 2006). Thus, it is important that the members of the team regularly discuss and critically reflect their beliefs, views, and values regarding ICT and early childhood education.

\footnotetext{
${ }^{22}$ As early childhood education teams consist of not only teachers but also teachers and nurses, I chose to use the term "educator" instead of "teacher" here.
} 
In addition, an individual teacher can have varied and sometimes even competing and contradictory beliefs regarding ICT use, depending on the frame through which he or she reflects on the topic. The preservice teachers emphasized care when they wrote about the education of the youngest children but stressed teaching when they discussed the education of older, pre-primary-aged children. In other words, if a teacher orients to his or her work from a profoundly care-related perspective, then his or her positive teaching-related beliefs may not actualize as pedagogical practices as the care-related risks surpass the teaching-related benefits (see also Howard, 2013). Some preservice teachers challenged the necessity of technology integration by suggesting that despite the potential benefits of technology integration, early childhood education should offer children an alternative environment in which no technology is used (see also FriedrichsLiesenkötter, 2015; Lindahl \& Folkesson, 2012a, 2012b). 


\section{Conclusions}

In this chapter, I first present the evaluation of the research which includes ethical considerations. Then, I discuss implications for early child education, teacher training, and future research.

\subsection{Evaluation of the research}

One way to look at the quality of research is to ask does the research address questions or issues that are important for scholarly knowledge and/or policy and practice (Moss et al., 2009). These questions relate to the worthiness of the research: What are the justifications for carrying out such a research project in the first place? The lack of attention by early childhood ICT integration research paid to the unique features of early childhood education has been acknowledged in several studies (Blackwell et al., 2013; Edwards, 2016; Plumb \& Kautz, 2015). A key motivation for this dissertation study was to contribute to this need. The second main motivation is related to theoretical contributions: As discussed in the Introduction, the current stage of research is dominated by discourses which emphasize either the assimilative or differentiated nature of early childhood ICT integration. Through exploring preservice teachers' beliefs and comparing them with children's ideas by scrutinizing the beliefs and ideas through third space theory, this dissertation was able to move beyond such discourses and provide a new framework for future research to apply.

In the context of the present study, another key question is the decision to focus on preservice teachers instead of in-service teachers. By doing so, the third space represented as the main result is still a "hypothetical space" as the children and preservice teachers who participated in this study did not work together. The reason behind this choice was that in much of the literature preservice teachers' voices were (at the time of writing this) marginalized in early childhood ICT integration research and that preservice teachers, in general, have often been treated as members of the digital natives generation, not as (future) educators (e.g., Lei, 2009; Szeto et al. 2016; Zaranis et al., 2016).

That being said, having a well-justified research topic does not itself equal good-quality research. Another feature highlighted by Pamela Moss et al. (2009) is the clarity of the central terms of the research. In the context of the present dissertation, the key themes are the third space and teachers' beliefs. In the Theory part (see Chapter 2), I articulated how my understanding of the third space as an 
intersectional space differs from the mainstream of third space studies. In addition, I provided an account of what I understand by teachers' beliefs and what the content of the beliefs studied in this dissertation is.

One more issue worth addressing is related to the methodological choices made during the research process: Are the methods used relevant to the research questions asked? Every research method has its strengths and weaknesses. Children's drawings (which were used as data in Article I) are often considered a less reliable and valid source of information than their writings and telling (Mavers, 2009 , p. 263), and drawings are usually seen as self-expression rather than as communication (Kress \& vanLeeuwen, 2006, p. 16). As the choice of words "considered" and "usually seen" point out, the assumptions of drawings" informative and communicative limitations are attitudes and viewpoints rather than facts. To get a better understanding of what the children wanted to say with their drawings, the children were also interviewed by using the drawing as a "mediating tool" (Horn \& Giacobbe, 2007; Lipponen et al., 2016; Spyrou, 2011). Similarly, the use of written assignments (which were used as data in Articles II and III) have pros and cons. Compared to interviews or other oral discussions, the benefit of written contributions is that the writers are able to check their own texts before forwarding them and to consider whether there is something they do not want to say (Uitto, 2011, 85). However, unlike in research interviews, the use of written contributions does not allow the researcher to ask the respondents clarifying questions.

The validity of the research is also related to the question of how (or whether) the interpretations made are supported by the data and are related to the previous research (Peräkylä, 2011). In all of the articles, the analysis (its phases and the decisions made) is reported in detail to make the interpretations as clear and understandable as possible for the reader (Ellingson, 2009, 2011). Similarly, all the arguments and claims expressed in the results of individual articles are supported with data extracts. I understand that because research questions determine how the data is read, I selected the data extracts (which are supposed to represent the participants' voices) from the full data set, and thus, they do not reflect the totality of the participants' experience (Atkins, et al., 2008; see also Karnieli-Miller et al., 2009). In addition, the question "who is the me who is doing the selections?" is an important one to answer as the researcher's subjectivity is intimately involved in qualitative research (Ellingson, 2011; Ratner, 2002). In the Introduction, I provided an account of my background and why I am interested in ICT integration and third space theory. 
Ethical questions are an important part of the evaluation of the research. Informed consent was asked from the children (oral), their guardians (written), as well as from the Department of Education (written) of the city where the data collection was carried out. Similarly, written consent was requested from the preservice teachers (Christians, 2011). Privacy issues were carefully considered, and it is not possible to identify the participants in the research articles. For example, as the data on the children (see Article I) was collected from a small-scale public development project, to protect their anonymity, the children's backgrounds are not discussed, and the children are not linked to the five preschools involved in the project. Similarly, in Articles II and III, instead of names (or even pseudonyms) the participating preservice teachers were referred to with ordinals. As matters of gender were not addressed in Articles II and III, all the preservice teachers were referred to with a feminine noun due to the female-oriented gender distribution (Kvåle \& Rambø, 2015).

Another ethics-related question is how the participants are informed about the outcomes of the research (Flewitt, 2005). In the context of the present study, neither of the data collections was "just" data collection. The data for Article I was collected as part of a development project, and the children's ideas were taken into consideration when planning how to integrate ICT-related content into the groups' pedagogical practices (see Mertala, 2015b; Salomaa \& Mertala, in press). Similarly, the data for Articles II and III was collected as part of a compulsory course in teacher education. The assignments were returned before the first contact lesson which made it possible for me to design and refine the content and methods of the course to meet the needs of these particular teacher students. In other words, the participants were informed about the preliminary findings right after the first screening of the data (see also Olafsdóttir \& Einarsdóttir, 2017).

\subsection{Implications of the research}

The research reported in this dissertation study has several implications for future research, the pedagogy of early childhood education, and teacher education. Next, I discuss these implications in separate subchapters.

\subsubsection{Implications for future research}

The research reported in this dissertation has several implications for future research. First, as the third space represented as the overarching result of this 
dissertation is still hypothetical, it is up to future research to examine the kind of third spaces that exist at the level of everyday educational practices. To give a concrete example, the intersectional interpretation of third space theory provides a useful theoretical framework for carrying out ethnographical research in preschools. An important research topic would be to study and compare the kinds of third spaces that take place in teacher-initiated activities and everyday practices both of which are considered educationally valuable in early childhood education (Venninen, Leinonen, Lipponen, \& Ojala, 2014). As the Ninjago example from Lehtikangas and Mulari's (2016) study suggested, children's first space knowledge is treated differently in teacher-initiated "pedagogized" third spaces (writing of NinjaGo stories) than in child-initiated practices (Ninjago role-play).

The intersectional interpretation of the third space introduced in this dissertation provides an interesting framework for studying third spaces, other than those that are strictly related to ICT, media, or literacies. Staying in the field of early childhood education, one option would be to study what kinds of third spaces are constructed during "toy days" when children bring their own toys to the preschool, present them to the teacher and other children, and then play "freely" with them (Ruckenstein, 2010). Previous research suggested that the playthings most valued by children are often unwanted by educators (Hartmann and Brougère, 2004; Wohlwend, 2017). It has been argued that toy days create educational challenges as toys suggest ideologies and narratives that are incompatible with the pedagogical culture of the preschool. Thus, the "toy day" interferes with the educational agenda (Ruckenstein, 2010, p. 505) creating what initially appear to be tensioned third spaces.

\subsubsection{Implications for pedagogical practices of early childhood education}

As children orient to digital games from a media cultural perspective, instead of merely using games early childhood education should (also) consider games as a subject of learning (Buckingham, 2015). This philosophy is actually already included in the Finnish National Core Curriculum's description of ICT competence as it calls teachers to examine games with children (Opetushallitus, 2016). According to David Buckingham and Andrew Burn (2007), learning games can be understood as a development of functional and critical game literacy. Functional literacy includes basic hardware skills (i.e., the ability to load and save a game) and software skills (i.e., the ability to navigate around the game space). Critical literacy, 
in turn, refers to the ability for a critical reflection of games, gameplay, and game culture. Although functional literacy can be practiced simply by playing different kinds of games, critical literacy requires different means. One way to support critical game literacy is to make games with children (Buckingham \& Burn, 2007). The rapid evolution of easy-to-use game programming tools (e.g., Scratch Jr.) has lowered the competence needed to create simple digital games.

However, more important than the form of the actual production is the knowledge construction that takes place during the pedagogical process, and examining digital games (or any other form of ICT) as a cultural form does not necessarily require any digital instruments. Teachers might ask children to tell them about their favorite games through visual methods, such as drawing, to support their thinking and narration. This approach first positions children as experts, and their teachers - who have been found to be unfamiliar with the contemporary digital media culture of children (Aubrey \& Dahl, 2014; Dong \& Newman, 2016) — can learn a great deal from them. However, at the same time, teachers can guide children's attention toward things they are not yet aware of. This can be done with simple concrete questions, such as "Why do you like this game?" and "Do you know how this game was made?" (Salomaa \& Mertala, in press).

As the children in the present dissertation study showed notable interest in photographing their doings in preschool, it is important to consider what pedagogical possibilities photographing would offer. As argued earlier, the visual medium can act as a mediating tool through which different parties are better able to understand each other's thinking (e.g., Lipponen et al., 2016; Spyrou, 2011), and this potential is not restricted to research processes. Research suggests that photograph-mediated discussions can provide children an opportunity to reflect on the reasons for their own and their peers' success (Mykkänen, Määttä, \& Järvelä, 2016). As supporting children's learning skills is named a common educational goal in the Finnish National Core Curriculum (Opetushallitus, 2016), such an approach provides notable pedagogical opportunities. Research also suggests that educational processes via digital photography give preschool children the ability to experiment with problem-solving and to develop curiosity and pleasure in learning, as well as independence, confidence, responsibility, empowerment, and participatory learning (Friedman, 2016).

In both examples (exploring games and taking pictures of meaningful things), children's topics of interest act as a starting point for phenomenon- and inquirybased learning processes that go beyond merely using different digital devices and content with the children. By doing so, early childhood ICT pedagogy can develop 
into a "transformative space where the potential for an expanded form of learning and the development of new knowledge are heightened" (Gutiérrez, 2008, p. 152).

\subsubsection{Implications for teacher education}

Currently, the educational technology courses in early childhood teacher education concentrate mainly on the introduction of appropriate resources and methods used in teaching (e.g., Istenic Starčič et al., 2016; Salomaa et al., 2017; Tokmak, 2013). As a concrete example, in a recent survey $77 \%$ of Finnish preservice teachers reported that they have been taught how to use ICT in teaching, but fewer than $20 \%$ reported that their training had included any information on how people use media. Fewer than $30 \%$ also reported that they had been taught about how to use media safely or about media-related risks (Salomaa et al., 2017). This finding is worrisome for (at least) two reasons. First, the emphasis on the uses of ICT as a tool for teaching, rather than on the socio-cultural approaches of digital technologies, in such courses teach students (at best) only a little about how children relate to ICT. As suggested in this dissertation, such knowledge is crucial for planning ICT-mediated practices. Second, teaching-centered approaches fail to pay respect to beliefs related to education and care, which, based on the findings in this dissertation, have a notable role in teachers' disposition toward ICT use.

As supporting children's ICT competence has become compulsory in Finnish early childhood education (Opetushallitus, 2016), this finding raises concerns not only about the quality of ICT-enhanced pedagogy but also regarding teachers' wellbeing. Situations in which a teacher feels compelled to increase the educational use of ICT even though it contradicts his or her personal educational values may cause tensions and "technostress" for teachers (Syvänen, Mäkiniemi, Syrjä, HeikkiläTammi, \& Viteli, 2016; see also Howard, 2013). Joce Nuttall et al. (2015, 233) recommended that ICT-related teacher training should pay attention to teachers' fears, hopes, and experiences because they provide "important clues about how to make professional development truly meaningful for teachers". Thus, drawing on the argument by Nuttal et al. (2015), it is worth asking what training solely related to teaching can offer to a (preservice) teacher who orients toward his or her (future) work from a profoundly care-related perspective.

Teachers can also act against curricular alignments or (pre)school policies if they think the policies are in contrast to children's foundational needs (Lynch \& Redpath, 2014; Marsh, 2006). As discussed in Articles II and III, preservice teachers' care- and education-related concerns were largely based on (unrealistic) 
beliefs of children's excessive ICT use at home, and it was noted that these beliefs prevent the preservice teachers from using ICT with children in preschool. Previous research suggested that the change in beliefs in teacher education demands that working with them must be given special attention in teacher education (Brownlee et al., 2001; Isikoglu, 2008). Therefore, educational technology courses must include critical reflection on preservice teachers' preconceptions and beliefs about children and technology. This applies to beliefs about children being digital natives. By questioning and challenging this unfounded belief, the pedagogical pitfall of assuming that children possess talents and abilities that they do not actually have can be avoided (Kirschner \& De Bruyckere, 2017). These notions summarize the key message of this dissertation: sensitive and (truly) child-centered early childhood education can be provided only when children are encountered as who they are, and not as who we hope or fear them to be. 


\section{References}

Aarsand, P. (2010). Young boys playing digital games. Nordic Journal of Digital Literacy, 5(1), 38-54. Retrieved from https://www.idunn.no/dk/2010/01/art04

Aarsand, P. (2011). Parenting and digital games: On children's game play in US families. Journal of Children and Media, 5(3), 318-333. https://doi.org/10.1080/17482798.2011.584382

Alasuutari, M., Karila, K., Alila, K., \& Eskelinen, M. (2014). Vaikuta varhaiskasvatukseen: Lasten ja vanhempien kuuleminen osana varhaiskasvatuksen lainsäädäntöprosessia [Hearing children and parents as part of the early childhood education legislative process]. Työryhmämuistioita ja selvityksiä 13. Opetus- ja kulttuuriministeriö. Retrieved from http://www.minedu.fi/export/sites/default/OPM/Julkaisut/2014/liitteet/tr13.pdf?lang=f i

Alliance for Childhood. (2004). Tech tonic: Towards a new literacy of technology. College Park, MD: Alliance for Childhood. Retrieved from https://eric.ed.gov/?id=ED485737

Angrosino, M., \& Rosenberg, J. (2011). Observations on observation. In N. Denzin \& Y. Lincoln (Eds.), The Sage handbook of qualitative research (pp. 467-478). Thousand Oaks, CA: Sage.

Anning, A., \& Ring, K. (2004). Making sense of children's drawings. Berkshire, United Kingdom: Open University Press.

Anyan, F. (2013). The influence of power shifts in data collection and analysis stages: A focus on qualitative research interview. The Qualitative Report, 18(18), 1-9.

Apple. (2013). Apple julkisti viimeisen vuosineljänneksen tuloksensa [Apple released its fourth-quarter results]. Retrieved from https://www.apple.com/fi/newsroom/2013/10/28Apple-Reports-Fourth-QuarterResults/

Ashton, P. (2015). Historical overview and theoretical perspectives of research on teachers' beliefs. In H. Fives \& M. G. Gills (Eds.), International handbook of research on teachers' beliefs (pp. 31-47). New York, NY: Routledge.

Aubrey, C., \& Dahl, S. (2014). The confidence and competence in information and communication technologies of practitioners, parents and young children in the Early Years Foundation Stage. Early Years, 34(1), 94-108. https://doi.org/10.1080/09575146.2013.792789

Avgitidou, S., Pnevmatikos, D., \& Likomitrou, S. (2013). Preservice teachers' beliefs about childhood: Challenges for a participatory early childhood education? Journal of Early Childhood Teacher Education, 340-404. https://doi.org/10.1080/10901027.2013.845633

Baum, A. C. (2000). Exploring the beliefs of early childhood preservice teachers. Iowa State University. Retrieved from https://lib.dr.iastate.edu/cgi/viewcontent.cgi?referer=https://www.google.fi/\&httpsredi $\mathrm{r}=1 \&$ article $=13307 \&$ context $=\mathrm{rtd}$ 
Baum, A. C., \& McMurray-Schwarz, P. (2004). Preservice teachers' beliefs about family involvement: Implications for teacher education. Early Childhood Education Journal, 32(1), 57-61. https://doi.org/10.1023/b:ecej.0000039645.97144.02

Beschorner, B., \& Hutchison, A. (2013). iPads as a literacy teaching tool in early childhood. International Journal of Education in Mathematics, Science and Technology, 1(1), 1624. Retrieved from https://files.eric.ed.gov/fulltext/EJ1055301.pdf

Bhabha, H. K. (1994). The location of culture. New York, NY: Routledge.

Biesta, G. (2010). Pragmatism and the philosophical foundations of mixed methods research. In A. Tashakkori \& C. Teddlie (Eds.), Sage handbook of mixed methods in social and behavioral research (2nd ed., pp. 95-117). Thousand Oaks, CA: Sage.

Biesta, G., Priestley, M., \& Robinson, S. (2015). The role of beliefs in teacher agency. Teachers and Teaching, 21(6), 624-640. https://doi.org/10.1080/13540602.2015.1044325

Blackwell, C. (2013). Teacher practices with mobile technology: integrating tablet computers into the early childhood classroom. Journal of Education Research, 7(4), 125. Retreieved from http://cmhd.northwestern.edu/wpcontent/uploads/2014/07/Blackwell-JEDR-Final.pdf

Blackwell, C. K., Lauricella, A. R., \& Wartella, E. (2014). Factors influencing digital technology use in early childhood education. Computers \& Education, 77, 82-90. https://doi.org/ 10.1016/j.compedu.2014.04.013

Blackwell, C. K., Lauricella, A. R., \& Wartella, E. (2016). The influence of TPACK contextual factors on early childhood educators' tablet computer use. Computers \& Education, 98, 57-69. https://doi.org/10.1016/j.compedu.2016.02.010

Blackwell, C. K., Wartella, E., Lauricella, A. R., \& Robb, M. (2015). Technology in the lives of educators and early childhood programs: Trends in access, use and professional development from 2012 to 2014. Center on Media and Human Development at Northwestern University, Evanston, IL. Retrieved from http://www.fredrogerscenter.org/wp-content/uploads/2015/07/Blackwell-WartellaLauricella-Robb-Tech-in-the-Lives-of-Educators-and-Early-Childhood-Programs.pdf

Blackwell, C. K., Lauricella, A. R., Wartella, E., Robb, M., \& Schomburg, R. (2013). Adoption and use of technology in early education: The interplay of extrinsic barriers and teacher attitudes. Computers \& Education, 69, 310-319. https://doi.org/10.1016/j.compedu.2013.07.024

Boeije, H. (2002). A purposeful approach to the constant comparative method in the analysis of qualitative interviews. Quality \& Quantity, 36(4), 391-409. https://doi.org/10.1023/A:1020909529486

Bølgan, N. (2012). From IT to tablet: Current use and future needs in kindergartens. Nordic Journal of Digital Literacy, 7(3), 154-171. Retrieved from https://www.idunn.no/dk/2012/03/from_it_to_tablet_current_use_and_future_needs_i n_kinderga

Braun, V., \& Clarke, V. (2006). Using thematic analysis in psychology. Qualitative Research in Psychology, 3(2), 77-101. https://doi.org/10.1191/1478088706qp063oa 
Broström, S. (2006). Care and education: Towards a new paradigm in early childhood education. Child and Youth Care Forum, 35(5-6), 391-409. https://doi.org/10.1007/s10566-006-9024-9

Broström, S. (2016). Ten-year-olds' reflections on their life in preschool. Nordic Studies in Education, 36(1), 3-19. https://doi.org/10.18261/issn.1891-5949-2016-01-02

Broström, S. (2017). A dynamic learning concept in early years' education: a possible way to prevent schoolification. International Journal of Early Years Education, 25(1), 3-15. https://doi.org/10.1080/09669760.2016.1270196

Broström, S., Sandberg, A., Johansson, I., Margetts, K., Nyland, B., Frøkjær, T., ... Vrinioti, K. (2015). Preschool teachers' views on children's learning: an international perspective. Early Child Development and Care, 185(5), 824-847. https://doi.org/10.1080/03004430.2014.958483

Brown, C. P., \& Englehardt, J. (2017). A case study of how a sample of preservice teachers made sense of incorporating iPads into their instruction with children. Journal of Early $\begin{array}{llll}\text { Childhood Teacher } & \text { Education, } & \text { 38(1), 38. }\end{array}$ https://doi.org/10.1080/10901027.2016.1274695

Brownlee, J. (2003). Changes in primary school teachers' beliefs about knowing: A longitudinal study. Asia-Pacific Journal of Teacher Education, 31(1), 87-98. https://doi.org/10.1080/13598660301621

Brownlee, J., Purdie, N., \& Boulton-Lewis, G. (2001). Changing epistemological beliefs in pre-service teacher education students. Teaching in Higher Education, 6(2), 247-268. https://doi.org//10.1080/13562510120045221

Buckingham, D. (2015). Defining digital literacy. Nordic Journal of Digital Literacy 10 (anniversary issue), 21-34. $\quad$ Retrieved from https://www.idunn.no/file/pdf/66808541/defining_digital_literacy__what_do_young_people_need_to_kn.pdf

Buckingham, D., \& Burn, A. (2007). Game literacy in theory and practice. Journal of Educational Multimedia and Hypermedia, 16(3), 323-349. Retrieved from https://search.proquest.com/docview/205847751?pq-origsite $=$ gscholar

Burkitt, E., Watling, D., \& Murray, L. (2011). Children's drawings of significant figures for a peer or an adult audience. Infant and Child Development, 20(6), 466-473. https://doi.org/10.1002/icd.735

Carr, W., \& Kemmis, S. (1986). Becoming critical: Education, knowledge and action research. London, United Kingdom: Falmer.

Chaudron, S., Beutel, M. E., Donoso Navarrete, V., Dreier, M., Fletcher-Watson, B., Heikkilä, A. S., ... Mascheroni, G. (2015). Young children (0-8) and digital technology: A qualitative exploratory study across seven countries. Publications Office of the European Union. Retrieved from http://publications.jrc.ec.europa.eu/repository/handle/JRC93239

Cheek, J. (2011). The politics and practices of funding qualitative inquiry. In N. K. Denzin \& Y. S. Lincoln (Eds.), The Sage handbook of qualitative research (pp. 251-268). Thousand Oaks, CA: Sage. 
Chenitz, W. C., \& Swanson, J. M. (1986). From practice to grounded theory: Qualitative research in nursing. Menlo Park, CA: Addison-Wesley.

Christians, C. G. (2011). Ethics and politics in qualitative research. In N. K. Denzin \& Y. S. Lincoln (Eds.), The Sage handbook of qualitative research (pp. 61-80). Thousand Oaks, CA: Sage

Common Sense Media (2017) Zero to eight: Children's media use in America 2017. Retrieved from https://www.commonsensemedia.org/research/the-common-sensecensus-media-use-by-kids-age-zero-to-eight-2017

Cook, M. (2005). "A place of their own": Creating a classroom "third space" to support a continuum of text construction between home and school. Literacy, 39(2), 85-90. https://doi.org/10.1111/j.1741-4350.2005.00405.x

Corbin, J. M., \& Strauss, A. (1990). Grounded theory research: Procedures, canons, and evaluative criteria. Qualitative Sociology, 13(1), 3-21. https://doi.org/10.1515/zfsoz1990-0602

Corsaro, W. A. (2005). The sociology of childhood (2nd ed.). Thousand Oaks, Ca: Sage.

Craig, S. D., Gholson, B., \& Driscoll, D. M. (2002). Animated pedagogical agents in multimedia educational environments: Effects of agent properties, picture features and redundancy. Journal of Educational Psychology, 94(2), 428-434. https://doi.org/0.1037//0022-0663.94.2.428

Creswell, J. W. (2011). Controversies in mixed methods research. In N. K Denzin, \& Y. S.Lincoln (Eds.), The Sage handbook of qualitative research (pp. 269-284). Thousand Oaks, CA: Sage.

Creswell, J. W., \& Plano Clark, V. L. (2007). Designing and conducting mixed methods research. Thousand Oaks, CA: Sage.

Dey, I. (2003). Qualitative data analysis: A user-friendly guide for social scientists. New York, NY: Routledge.

Denzin, N. K., \& Lincoln, Y. S. (2011a). Introduction: The disclipine and practice of qualitative research. In N. K. Denzin \& Y. S. Lincoln (Eds.), The Sage handbook of qualitative research (pp. 1-20). Thousand Oaks, CA: Sage.

Denzin, N. K., \& Lincoln, Y. S. (2011b). Methods of collecting and aaalyzing empirical materials. In N. K. Denzin \& Y. S. Lincoln (Eds.), The Sage handbook of qualitative research (pp. 415-420). Thousand Oaks, CA: Sage.

Dickie, J., \& Shuker, M. J. (2014). Ben 10, superheroes and princesses: primary teachers' views of popular culture and school literacy. Literacy, 48(1), 32-38. https://doi.org/10.1111/lit.12023

van Dijk, J. A. (2006). Digital divide research, achievements and shortcomings. Poetics, 34(4), 221-235. https://doi.org/10.1016/j.poetic.2006.05.004

Dong, C., \& Newman, L. (2016). Ready, steady ... pause: integrating ICT into Shanghai preschools. International Journal of Early Years Education, 24(2), 224-237. https://doi.org/10.1080/09669760.2016.1144048

Donmoyer, R. (2000). Generalizability and the single-case study. In R. Gomm, M. Hammersley, \& P. Foster (Eds.) Case study method: Key issues, key texts (pp.45-68). Thousand Oaks, CA: Sage. 
Driessnack, M. (2006). Draw-and-tell conversations with children about fear. Qualitative Health Research, 16(10), 1414-1435. https://doi.org/10.1177/1049732306294127

Driessnack, M., \& Gallo, A. M. (2013). Children "draw-and-tell" 'their knowledge of genetics. Pediatric Nursing, 39(4), 173-180. Retrieved from https://www.ncbi.nlm.nih.gov/pubmed/24027951

Dunn, J., Gray, C., Moffett, P., \& Mitchell, D. (2016). "It's more funner than doing work": Children's perspectives on using tablet computers in the early years of school. Early Child Development and Care. Advance online publication. https://doi.org/10.1080/03004430.2016.1238824

Dyson, A. H. (2003). "Welcome to the jam": Popular culture, school literacy, and the making of childhoods. Harvard Educational Review, 73(3), 328-361. https://doi.org/10.17763/haer.73.3.d262234083374665

Dyson, A. H (2010). Writing childhoods under construction: Re-visioning "copying”in early childhood. Journal of Early Childhood Literacy, 10(1), 7-31. https://doi.org/: $10.1177 / 1468798409356990$

Edwards, S. (2013). Digital play in the early years: A contextual response to the problem of integrating technologies and play-based pedagogies in the early childhood curriculum. European Early Childhood Education Research Journal, 21(2), 199-212. https://doi.org/10.1080/1350293x.2013.789190

Edwards, S., Henderson, M., Gronn, D., Scott, A., \& Mirkhil, M. (2017). Digital disconnect or digital difference? A socio-ecological perspective on young children's technology use in the home and the early childhood centre. Technology, Pedagogy and Education, 26(1), 1-17. https://doi.org/10.1080/1475939x.2016.1152291

Einarsdóttir, J. (2003). The role of preschools and preschool teachers: Icelandic preschool educators' discourses. Early Years: An International Journal of Research and Development, 23(2), 103-116. https://doi.org/10.1080/09575140303110

Einarsdóttir, J. (2007). Research with children: Methodological and ethical challenges. European Early Childhood Education Research Journal, 15(2), 197-211. https://doi.org/0.1080/13502930701321477

Einarsdóttir, J. (2014). Children's perspectives on the role of preschool teachers. European Early Childhood Education Research Journal, 22(5), 679-697. https://doi.org/10.1080/1350293x.2014.969087

Einarsdóttir, J., Dockett, S., \& Perry, B. (2009). Making meaning: Children's perspectives expressed through drawings. Early Child Development and Care, 179(2), 217-232. https://doi.org/10.1080/03004430802666999

Elbaz-Luwisch, F., Moen, T., \& Gudmundsdottir, S. (2002). The multivoicedness of classrooms: Bakhtin and narratives of teaching. In R. Huttunen, H. L. T. Heikkinen, \& L. Syrjälä (Eds.), Narrative research: Voices from teachers and philosophers (pp. 197218). Jyväskylä: SoPhi.

Ellingson, L. L. (2009). Engaging crystallization in qualitative research: An introduction. Thousand Oaks, CA: Sage. 
Ellingson, L. L. (2013). Analysis and representation across the continuum: Collecting and interpreting qualitative materials. In N. K. Denzin \& Y. S. Lincoln (Eds.), Collecting and interpreting qualitative materials (pp. 413-445). Thousand Oaks, CA: Sage,

Elo, S., \& Kyngäs, H. (2008). The qualitative content analysis process. Journal of Advanced Nursing, 62(1), 107-115. https://doi.org/107-115. 10.1111/j.1365-2648.2007.04569.x

Engeström, Y. (2005). Developmental work research: Expanding activity theory in practice (Vol. 12). Berlin, Germany: Lehmanns Media.

Erickson, F. (2011). A history of qualitative inquiry in social and educational research. In N. K. Denzin \& Y. S. Lincoln (Eds.), The Sage handbook of qualitative research (pp. 4359). Thousand Oaks, CA: Sage.

Ertmer, P. A. (2005). Teacher pedagogical beliefs: The final frontier in our quest for technology integration? Educational Technology Research and Development, 53(4), 25-39. https://doi.org/10.1007/bf02504683

Ertmer, P. A., Ottenbreit-Leftwich, A. T., Sadik, O., Sendurur, E., \& Sendurur, P. (2012). Teacher beliefs and technology integration practices: A critical relationship. Computers \& Education, 59(2), 423-435. https://doi.org/10.1016/j.compedu.2012.02.001

Estola, E., Erkkilä. R. \& Syrjälä, L. (2003). A moral voice of vocation in teachers' narratives. Teachers and Teaching, 9(3), 239-256. https://doi.org/10.1080/13540600309381

Eurostat. (2014). Internet access in households by income quartile. Retrieved from http://ec.europa.eu/eurostat/statistics-

explained/index.php/File:Internet_access_in_households_by_income_quartile,_2014 $\% 28 \%$ C2\%B9\%29_\%28\%25_of_all_households\%29_YB15.png

Fang, Z. (1996). A review of research on teacher beliefs and practices. Educational Research, 38(1), 47-65. https://doi.org/10.1080/0013188960380104

Fenty, N. S., \& Anderson, E. M. (2014). Examining educators' knowledge, beliefs, and practices about using technology with young children. Journal of Early Childhood Teacher Education, 35(2), 114-134. https://doi.org/10.1080/10901027.2014.905808

Fenwick, T., \& Landri, P. (2012). Materialities, textures and pedagogies: socio-material assemblages in education. Pedagogy, Culture \& Society, 20(1), 1-7. https://doi.org/0.1080/14681366.2012.649421

Fives, H., \& Buehl, M. M. (2012). Spring cleaning for the "messy" construct of teachers' beliefs: What are they? Which have been examined? What can they tell us? In K. R. Harris, S. Graham, \& T. Urdan (Eds.), APA educational psychology handbook: Individual differences and cultural and contextual factors (pp. 471-499). Wachington, DC: American Psychological Association.

Flewitt, R. (2005). Conducting research with young children: Some ethical considerations. Early Child Development and Care, 175(6), 553-565. https://doi.org/10.1080/03004430500131338

Flewitt, R., Messer, D., \& Kucirkova, N. (2015). New directions for early literacy in a digital age: The iPad. Journal of Early Childhood Literacy, 15(3), 289-310. https://doi.org/10.1177/1468798414533560 
Fram, S. M. (2013). The constant comparative analysis method outside of grounded theory. The Qualitative Report, 18(1), 1-25. Retrieved from http://nsuworks.nova.edu/tqr/vol18/iss1/1/

Friedman, A. (2016). Three-year-old photographers: Educational mediation as a basis for visual literacy via digital photography in early childhood. Journal of Media Literacy Education, 8(1), 15-31. Retrieved from https://files.eric.ed.gov/fulltext/EJ1108349.pdf

Friedrichs-Liesenkötter, H. (2015). Media-educational habitus of future educators in the context of education in day-care centers. Journal of Media Literacy Education, 7(1), 18-34. Retrieved from https://files.eric.ed.gov/fulltext/EJ1074780.pdf

Funkhouser, B. J., \& Mouza, C. (2013). Drawing on technology: An investigation of preservice teacher beliefs in the context of an introductory educational technology course. Computers \& Education, 62, 271-285. https://doi.org/10.1016/j.compedu.2012.11.005

Fusch, P. I., \& Ness, L. R. (2015). Are we there yet? Data saturation in qualitative research. The Qualitative Report, 20(9), 1408-1416. Retrieved from http://www.nova.edu/ssss/QR/QR20/9/fusch1.pdf

Goffman, E. (1974). Frame analysis: An essay on the organization of experience. Cambridge, MA: Harvard University Press.

Gourlay, L., Lanclos, D. M., \& Oliver, M. (2015). Sociomaterial texts, spaces and devices: Questioning "digital dualism"in library and study practices. Higher Education Quarterly, 69(3), 263-278. https://doi.org/10.1111/hequ.12075

Graue, E. (2005). Theorizing and describing preservice teachers' images of families and schooling. Teachers College Record, 107(1), 157-185. https://doi.org/10.1111/j.14679620.2005.00461.x

Grönfors, M. (2011). Laadullisen tutkimuksen kenttätyömenetelmät [Field methods of qualitative research]. Hämeenlinna, Finland: SoFia-Sosiologi-Filosofiapu Vilkka. Retrieved from http://vilkka.fi/books/Laadullisen_tutkimuksen.pdf

Gutiérrez, K. D. (2008). Developing a sociocritical literacy in the third space. Reading Research Quarterly, 43(2), 148-164. https://doi.org/10.1598/rrq.43.2.3

Gutiérrez, K. D., Baquedano-López, P., \& Tejeda, C. (1999). Rethinking diversity: Hybridity and hybrid language practices in the third space. Mind, Culture, and Activity, 6(4), 286-303. https://doi.org/10.1080/10749039909524733

Hartmann, W., \& Brougère, G. (2004). Toy culture in preschool education and children's toy preferences. In J. Goldstein, D. Buckingham, \& G. Brougère (Eds.), Toys, Games, and Media (pp. 37-54). Mahwah, NJ: Erlbaum.

Hernwall, P. (2016). "We have to be professional" - Swedish preschool teachers' conceptualisation of digital media. Nordic Journal of Digital Literacy, 11(1), 5-23. https://doi.org/0.18261/issn.1891-943x-2016-01-01

Hopkins, W. G. (2008). Quantitative research design. Retrieved from http://www.citeulike.org/group/6675/article/3424132

Horn, M., \& Giacobbe, M. E. (2007). Talking, drawing, writing: Lessons for our youngest writers. Portland, ME: Stenhouse. 
Howard, S. K. (2013). Risk-aversion: Understanding teachers' resistance to technology integration. Technology, Pedagogy and Education, 22(3), 357-372. https://doi.org/10.1080/1475939x.2013.802995

Hujala, E., Turja, L., Gaspar, M. F., Veisson, M., \& Waniganayake, M. (2009). Perspectives of early childhood teachers on parent-teacher partnerships in five European countries. European Early Childhood Education Research Journal, 17(1), 57-76. https://doi.org/10.1080/13502930802689046

Ihmeideh, F. (2009). The role of computer technology in teaching reading and writing: Preschool teachers' beliefs and practices. Journal of Research in Childhood Education, 24(1), 60-79. https://doi.org/10.1080/02568540903439409

Ihmeideh, F., \& Alkhawaldeh, M. (2017). Teachers' and parents' perceptions of the role of technology and digital media in developing child culture in the early years. Children and Youth Services Review, 77, 139-146. https://doi.org/10.1016/j.childyouth.2017.04.013

Ingleby, E. (2015). The impact of changing policies about technology on the professional development needs of early years educators in England. Professional Development in Education, 41(1), 144-157. https://doi.org/10.1080/19415257.2014.894482

Isikoglu, N. (2008). The effects of a teaching methods course on early childhood preservice teachers' beliefs. Journal of Early Childhood Teacher Education, 29(3), 190-203. https://doi.org/0.1080/10901020802275260

Istenic Starčič, A., Cotic, M., Solomonides, I., \& Volk, M. (2016). Engaging preservice primary and preprimary school teachers in digital storytelling for the teaching and learning of mathematics. British Journal of Educational Technology, 47(1), 29-50. https://doi.org/10.1111/bjet.12253

Izumi-Taylor, S., Ito, Y., \& Gibbons, A. (2010). Early childhood pre-service teachers' perceptions of teaching technology to children in Japan and the United States. Research in Comparative and International Education, 5(4), 408-420. https://doi.org/10.2304/rcie.2010.5.4.408

Jamieson, D. W., \& Thomas, K. W. (1974). Power and conflict in the student-teacher relationship. The Journal of Applied Behavioral Science, 10(3), 321-336. https://doi.org/10.1177/002188637401000304

Jimoyiannis, A., \& Komis, V. (2007). Examining teachers' beliefs about ICT in education: Implications of a teacher preparation programme. Teacher Development, 11(2), 149173. https://doi.org/10.1080/13664530701414779

Johansson, E., Puroila, A.-M., \& Emilson, A. (2016). Research project overview: Values education in Nordic preschools - Basis of education for tomorrow. International Journal of Early Childhood, 48(2), 137-139. https://doi.org/10.1007/s13158-016-0169$\mathrm{x}$

Karnieli-Miller, O., Strier, R., \& Pessach, L. (2009). Power relations in qualitative research. Qualitative Health Research, 19(2), 279-289. https://doi.org/10.1177/1049732308329306 
Kim, C., Kim, M. K., Lee, C., Spector, J. M., \& DeMeester, K. (2013). Teacher beliefs and technology integration. Teaching and Teacher Education, 29, 76-85. https://doi.org/10.1016/j.tate.2012.08.005

Kirschner, P. A., \& De Bruyckere, P. (2017). The myths of the digital native and the multitasker. Teaching and Teacher Education, 67, 135-142. https://doi.org/10.1016/j.tate.2017.06.001

Kjällander, S., \& Moinian, F. (2014). Digital tablets and applications in preschool Preschoolers' creative transformation of didactic design. Designs for Learning, 7(1), 10-33. https://doi.org/10.2478/dfl-2014-0009

Knauf, H. (2016). Interlaced social worlds: Exploring the use of social media in the $\begin{array}{llll}\text { kindergarten. } & \text { Early } & \text { Years, } & \text { 254-270. }\end{array}$ https://doi.org/10.1080/09575146.2016.1147424

Koivula, M, \& Mustola, M. (2017). Varhaiskasvatuksen digiloikka ja muuttuva sukupolvijärjestys? Jännitteitä lastentarhanopettajien ja lasten kohtaamisissa digitaalisen teknologian äärellä [Digitization of early childhood education and changing generation order? Tensions between teachers and children in encounters with digital technology]. Kasvatus \& Aika, 11(3), 37-50. Retrieved from https://journal.fi/kasvatusjaaika/article/view/68722

Kowalski, K., Pretti-Frontczak, K., \& Johnson, L. (2001). Preschool teachers' beliefs concerning the importance of various developmental skills and abilities. Journal of Research in Childhood Education, 16(1), 5-14. https://doi.org/10.1080/02568540109594970

Kumar, S., \& Vigil, K. (2011). The net generation as preservice teachers: Transferring familiarity with new technologies to educational environments. Journal of Digital Learning in Teacher Education, 27(4), 144-153. https://doi.org/10.1080/21532974.2011.10784671

Kupiainen, R. (2013). Dissolving the school space: Young people's media production in and outside of school. Policy Futures in Education, 11(1), 37--46. https://doi.org/10.2304/pfie.2013.11.1.37

Kvale, S., \& Brinkmann, S. (2009). Interviews: Learning the craft of qualitative interviewing (2nd ed.). Thousand Oaks, CA: Sage.

Kvåle, G., \& Rambø, G. R. (2015). Expressing professional identity through blogging - A case study of blogging in the study of the subject of Norwegian in pre-school teacher education. Nordic Journal of Digital Literacy, 9(1), 8-28. Retrieved from https://www.idunn.no/dk/2015/01/expressing_professional_identity_through_bloggin g_-_a_case

Lafton, T. (2012). How early childhood practitioners build, shape, and construct their digital practices: The search for an analytical space. Nordic Journal of Digital Literacy, 7(3), $172-186$.

Retrieved

from

https://www.idunn.no/dk/2012/03/how_early_childhood_practitioners_build_shape_a nd_constru 
Lasky, S. (2005). A sociocultural approach to understanding teacher identity, agency and professional vulnerability in a context of secondary school reform. Teaching and Teacher Education, 21(8), 899-916. https://doi.org/10.1016/j.tate.2005.06.003

Lee, J. S. (2006). Preschool teachers' shared beliefs about appropriate pedagogy for 4-yearolds. Early Childhood Education Journal, 33(6), 433-441. https://doi.org/10.1007/s10643-006-0059-1

Lehtikangas, A. \& Mulari, H. (2016) "Mä en oo kattonu mut mä vaan tiiän ne”: Havainnointi, medialeikit ja eronteot päiväkodissa ["I haven't watched them. I jus know them": Observation, media play, and distinctions in kindergarten]. In H. Mulari (Eds.), Solmukohtia: Näkökulmia lasten mediakulttuurien tutkimusmenetelmiin ja mediakasvatukseen (pp. 55-78). Nuorisotutkimusverkosto/Nuorisotutkimusseura: Verkkojulkaisuja $103 . \quad$ Retrieved from http://www.nuorisotutkimusseura.fi/images/julkaisuja/solmukohtia.pdf

Lei, J. (2009). Digital natives as preservice teachers: What technology preparation is needed? Journal of Computing in Teacher Education, 25(3), 87-97.

Levin, B. B. (2015). The development of teachers' beliefs. In H. Fives \& M. G. Gills (Eds.), International handbook of research on teachers' beliefs (pp. 48-65). New York, NY: Routledge.

Lindahl, M. G., \& Folkesson, A. M. (2012a). Can we let computers change practice? Educators' interpretations of preschool tradition. Computers in Human Behavior, 28(5), 1728-1737. https://doi.org/10.1016/j.chb.2012.04.012

Lindahl, M. G., \& Folkesson, A. M. (2012b). ICT in preschool: Friend or foe? The significance of norms in a changing practice. International Journal of Early Years Education, 20(4), 422-436. https://doi.org/0.1080/09669760.2012.743876

Lipponen, L., Rajala, A., Hilppö, J., \& Paananen, M. (2016). Exploring the foundations of visual methods used in research with children. European Early Childhood Education Research Journal, 24(6), 936--946. https://doi.org/10.1080/1350293x.2015.1062663

Livingstone, S., Haddon, L., Görzig, A., \& Ólafsson, K. (2011). Risks and safety on the internet: The perspective of European children: Full findings and policy implications from the EU kids online survey of 9-16 year olds and their parents in 25 countries. London, United Kingdom: EU Kids Online. Retrieved from http://eprints.lse.ac.uk/33731/

Lu, Y. H., Ottenbreit-Leftwich, A. T., Ding, A. C., \& Glazewski, K. (2017). Experienced iPad-using early childhood teachers: Practices in the one-to-one iPad classroom. Computers in the Schools, 34(1-2), 9-23. https://doi.org/10.1080/07380569.2017.1287543

Lundby, E. (2013). "You can't buy friends, but"... Children's perception of consumption and friendship. Young Consumers, 14(4), 360-374. https://doi.org/10.1108/yc-03-201300347

Lynch, J., \& Redpath, T. (2014). "Smart" technologies in early years literacy education: A meta-narrative of paradigmatic tensions in iPad use in an Australian preparatory classroom. Journal of Early Childhood Literacy, 14(2), 147-174. https://doi.org/10.1177/1468798412453150 
Mansour, N. (2008). The experiences and personal religious beliefs of Egyptian science teachers as a framework for understanding the shaping and reshaping of their beliefs and practices about science-technology-society (STS). International Journal of Science Education, 30(12), 1605-1634. https://doi.org/10.1080/09500690701463303

Mantere, E., \& Raudaskoski, S (2017): The sticky media device. In \& A. R Lahikainen, K. Repo, \& T. Mälkiä (Eds.), Media, family interaction and the digitalisation of childhood (pp. 135-154). Cheltenham, United Kingdom: Elgar.

Marklund, L., \& Dunkels, E. (2016). Digital play as a means to develop children's literacy and power in the Swedish preschool. Early Years, 36(3), 289-304. https://doi.org/10.1080/09575146.2016.1181608

Marsh, J. (2006). Popular culture in the literacy curriculum: A Bourdieuan analysis. Reading Research Quarterly, 41(2), 160-174. https://doi.org/10.1598/rrq.41.2.1

Marsh, J., Plowman, L., Yamada-Rice, D., Bishop, J. C., Lahmar, J., Scott, F., \& Winter, P. (2015). Exploring play and creativity in pre-schoolers' use of apps: Final project report. Retrieved from http://www.techandplay.org/TAP_Final\%20Report.pdf

Mavers, D. (2009). Image in the multimodal ensemble: Children's drawings. In C. Jewitt (Ed.), Routledge handbook of multimodal analysis (pp. 263-271). New York, NY: Routledge.

Maxwell, J. A., \& Mittapalli, K. (2010). Realism as a stance for mixed methods research. In A. Tashakkori \& C. Teddlie (Eds.), Handbook of mixed methods in social and behavioral research (pp. 145-168). Thousand Oaks, CA: Sage.

McCracken, G. (1988). The long interview. Thousand Oaks, CA: Sage.

McKenney, S., \& Voogt, J. (2010). Technology and young children: How 4-7 year olds perceive their own use of computers. Computers in Human Behavior, 26(4), 656-664. https://doi.org/10.1016/j.chb.2010.01.002

Meehan, C., \& Meehan, P. J. (2017). Trainee teachers' perceptions about parent partnerships: are parents partners? Early Child Development and Care. Advance online publication. https://doi.org/10.1080/03004430.2017.1286334

Mertala, P. (2015a). Kolmas tila suhteisuuden näyttämönä - Mediaviitteet ja läheisten nimet yhteisöllisyyden osoittajina esiopetusikäisten lasten luovassa kirjoittamisessa [Third space and relations - Media references and the names of friends and family as indicators of communality in preschoolers' creative writing]. Media \& viestintä, 38(1), 40-56. https://doi.org/10.23983/mv.62109

Mertala, P. (2015b). Tieto- ja viestintätekniikka ja työssä oppiminen - (Mikro)kertomuksia esiopetuksesta [ICT and in-job-learning - (Micro)stories from pre-primary education]. Aikuiskasvatus, 35(3), 189-198. Retrieved from http://elektra.helsinki.fi/se/a/03586197/35/3/tietojav.pdf

Mertala, P. (2017). Wag the dog - The nature and foundations of preschool educators' positive ICT pedagogical beliefs. Computers in Human Behavior, 69, 197-206. https://doi.org/10.1016/j.chb.2016.12.037

Miles, M. B., Huberman, A. M., \& Saldana, J. (2013). Qualitative data analysis. Thousand Oaks, CA: Sage. 
Moje, E. B., Ciechanowski, K. M., Kramer, K., Ellis, L., Carrillo, R., \& Collazo, T. (2004). Working toward third space in content area literacy: An examination of everyday funds of knowledge and discourse. Reading Research Quarterly, 39(1), 38-70. https://doi.org/10.1598/rrq.39.1.4

Morgan, A. (2010). Interactive whiteboards, interactivity and play in the classroom with children aged three to seven years. European Early Childhood Education Research Journal, 18(1), 93-104. https://doi.org/10.1080/13502930903520082

Moss, P. (2006). Structures, understandings and discourses: Possibilities for re-envisioning the early childhood worker. Contemporary Issues in Early Childhood, 7(1), 30-41. https://doi.org/doi.org/10.2304/ciec.2006.7.1.30

Moss, P. A., Phillips, D. C., Erickson, F. D., Floden, R. E., Lather, P. A., \& Schneider, B. L. (2009). Learning from our differences: A dialogue across perspectives on quality in education research. Educational Researcher, 38(7), 501-517. https://doi.org/10.3102/0013189x09348351

Muller, C. (2001). The role of caring in the teacher-student relationship for at-risk students. Sociological Inquiry, 71(2), 241-255. https://doi.org/10.1111/j.1475682x.2001.tb01110.x

Mykkänen, A., Määttä, E., \& Järvelä, S. (2016). "What makes her succeed?” Children's interpretations of their peers' successes in learning situations. International Journal of Early Years Education, https://doi.org/10.1080/09669760.2015.1110515

Nespor, J. (1987). The role of beliefs in the practice of teaching. Journal of Curriculum Studies, 19(4), 317-328. https://doi.org/10.1080/0022027870190403

Newman, I., \& Benz, C. R. (1998). Qualitative-quantitative research methodology: Exploring the interactive continuum. Carbondale, IL: SIU Press.

Niikko, A. (2004). Education - A joint task for parents, kindergarten teachers and kindergarten student teachers. International Journal of Early Years Education, 12(3), 259-274. https://doi.org/10.1080/0966976042000268726

Niikko, A., \& Ugaste, A. (2012). Conceptions of Finnish and Estonian pre-school teachers' goals in their pedagogical work. Scandinavian Journal of Educational Research, 56(5), 481-495. https://doi.org/10.1080/00313831.2011.599424

Nikolopoulou, K., \& Gialamas, V. (2015). ICT and play in preschool: Early childhood teachers' beliefs and confidence. International Journal of Early Years Education, 23(4), 409-425. https://doi.org/10.1080/09669760.2015.1078727

Noppari, E. (2014). Mobiilimuksut. Lasten ja nuorten mediaympäristön muutos, osa 3 [Change of media environment of children and young people, Part 3]. Tampere Research Centre for Journalism, Media and Communication. Retrieved from http://www.uta.fi/cmt/index/mobiilimuksut.pdf

Nuttall, J., Edwards, S., Mantilla, A., Grieshaber, S., \& Wood, E. (2015). The role of motive objects in early childhood teacher development concerning children's digital play and play-based learning in early childhood curricula. Professional Development in Education, 41(2), 222-235. https://doi.org/10.1080/19415257.2014.990579 
Näykki, P. (2014). Affective and effective collaborative learning: Process oriented design studies in a teacher education context. Acta Universitatis Ouluensis. E, Scientiae Rerum Socialium 151. Oulu, Finland: The University of Oulu. Retrieved from http://jultika.oulu.fi/files/isbn9789526206882.pdf

OECD (2017). Education at a glance 2017: OECD indicators. Paris, France: OECD Publishing. http://dx.doi.org/10.1787/eag-2017-en

O'Connor, K. E. (2008). "You choose to care": Teachers, emotions and professional identity. Teaching and Teacher Education, 24(1), 117-126. https://doi.org/10.1016/j.tate.2006.11.008

O'Connor, M. K., Netting, F. E., \& Thomas, M. L. (2008). Grounded theory: Managing the challenge for those facing institutional review board oversight. Qualitative Inquiry, 14(1), 28-45. https://doi.org/10.1177/1077800407308907

Ólafsdóttir, S. M., \& Einarsdóttir, J. (2018). "Drawing and playing are not the same": Children's views on their activities in Icelandic preschools. Early Years. Advance online publication. https://doi.org/10.1080/09575146.2017.1342224

de Oliveira Nascimento, A. K., \& Knobel, M. (2017). What's to be learned? A review of sociocultural digital literacies research within pre-service teacher education. Nordic Journal of Digital Literacy, 12(3), 67-88. https://doi.org/10.18261/issn.1891-943x2017-03-03

Onnismaa, E. L. (2010). Lapsi, lapsuus ja perhe varhaiskasvatusasiakirjoissa 1967-1999 [Child, childhood, and family in early childhood education documents 1967-1999]. Tutkimuksia 313. Helsingin Yliopisto. Retrieved from https://helda.helsinki.fi/bitstream/handle/10138/20012/lapsilap.pdf

Onnismaa, E. L., \& Kalliala, M. (2010). Finnish ECEC policy: Interpretations, implementations and implications. Early Years, 30(3), 267-277. https://doi.org/10.1080/09575146.2010.511604

Onwuegbuzie, A. J. (2003). Effect sizes in qualitative research: A prolegomenon. Quality and Quantity, 37(4), 393-409. https://doi.org/10.18261/issn.1891-943x-2017-03-03

Onwuegbuzie, A. J., \& Combs, J. P. (2010). Emergent data analysis techniques in mixed methods research: A synthesis. In A. Tashakkori \& C. Teddlie (Eds.), Sage handbook of mixed methods in social and behavioral research (2nd ed., pp. 397-430). Thousand Oaks, CA: Sage.

Onwuegbuzie, A. J., Slate, J. R., Leech, N. L., \& Collins, K. M. (2007). Conducting mixed analyses: A general typology. International Journal of Multiple Research Approaches, 1(1), 4-17. https://doi.org/10.5172/mra.455.1.1.4

Onwuegbuzie, A. J., \& Teddlie, C. (2003). A framework for analyzing data in mixed methods research. In A. Tashakkori \& C. Teddlie (Eds.), Handbook of mixed methods in social and behavioral research (pp. 397-430). Thousand Oaks, CA: Sage.

Opetushallitus. (2014). Esiopetuksen opetussuunnitelman perusteet [National core curriculum guidelines for pre-primary education]. Määräykset ja ohjeet 1 . Retrieved from

http://www.oph.fi/download/163781_esiopetuksen_opetussuunnitelman_perusteet_20 14.pdf 
Opetushallitus. (2016). Varhaiskasvatussuunnitelman perusteet [National core curriculum guidelines for early childhood education]. Määräykset ja ohjeet 17. Retrieved from http://www.oph.fi/download/179349_varhaiskasvatussuunnitelman_perusteet_2016.p df

Orlikowski, W. J. (2007). Sociomaterial practices: Exploring technology at work. Organization Studies, 28(9), 1435-1448. https://doi.org/10.1177/0170840607081138

Osborn, M., Croll, P., Broadfoot, P., Pollard, A., McNess, E., \& Triggs, P. (1997). Policy into practice and practice into policy: Creative mediation in the primary classroom. In G. Helsby \& G. McCulloch (Eds.), Teachers and the national curriculum (pp. 52-65). London, United Kingdom: Cassell.

Pahl, K., \& Kelly, S. (2005). Family literacy as a third space between home and school: Some case studies of practice. Literacy, 39(2), 91-96. https://doi.org/10.1111/j.17414350.2005.00406.x

Pahl, K., \& Rowsell, J. (2005). Literacy and education: Understanding new literacy studies in the classroom. Thousand Oaks, CA: Sage.

Pajares, M. F. (1992). Teachers' beliefs and educational research: Cleaning up a messy construct. Review of Educational Research, 62(3), 307-332. https://doi.org/10.2307/1170741

Palaiologou, I. (2016a). Children under five and digital technologies: implications for early years pedagogy. European Early Childhood Education Research Journal, 24(1), 5-24. https://doi.org/10.1080/1350293x.2014.929876

Palaiologou, I. (2016b). Teachers' dispositions towards the role of digital devices in playbased pedagogy in early childhood education. Early Years, 36(3), 305-321. https://doi.org/10.1080/09575146.2016.1174816

Palaiologou, I. (2017). Digital violence and children under five: The phantom menace within digital homes of the 21 st century? Education Sciences \& Society-Open Access Journal, 8(1), 123-136. https://doi.org/10.3280/ess1-2017oa4978

Pálmadóttir, H., \& Einarsdóttir, J. (2015). Young children's views of the role of preschool educators. Early Child Development and Care, 185(9), 1480-1494. https://doi.org/10.1080/03004430.2015.1004056

Palmgren-Neuvonen, L., Jaakkola, M., \& Korkeamäki, R. -L. (2015). School-context videos in Janus-faced online publicity: Learner-generated digital video production going online. Scandinavian Journal of Educational Research, 59(3), 255-274. https://doi.org/:10.1080/00313831.2014.996599

Papadakis, S., Kalogiannakis, M., \& Zaranis, N. (2018). Educational apps from the Android Google Play for Greek preschoolers: A systematic review. Computers \& Education, 116, 139-160. https://doi.org/10.1016/j.compedu.2017.09.007

Parker, A., \& Neuharth-Pritchett, S. (2006). Developmentally appropriate practice in kindergarten: Factors shaping teacher beliefs and practice. Journal of Research in Childhood Education, 21(1), 65-78. https://doi.org/10.1080/02568540609594579

Patton, M. Q. (2002). Qualitative research and evaluation methods ( $3 \mathrm{rd} \mathrm{ed})$. Thousand Oaks, CA: Sage. 
Pennanen, S. (2009). Lasten medialeikit päiväkodissa [Children's media plays in kindergarten]. In L. Alanen \& K. Karila (Eds.), Lapsuus, lapsuuden instituutiot ja lasten toiminta (pp. 182-206). Tampere, Finland: Vastapaino.

Perusopetuslaki 21.8.1998/628 (26 a $\S, \quad 12.12 .2014 / 1040)$ Retrieved from https://www.finlex.fi/fi/laki/ajantasa/1998/19980628\#L7P26a

Peräkylä, A. (2011) Validity in research on naturally occurring social interaction. In D. Silverman (Ed.), Interpreting qualitative data: A guide to the principles of qualitative research (pp. 366-382). Thousand Okas, CA: Sage.

Petersen, P. (2015). "That's how much I can do!" - Children's agency in digital tablet activities in a Swedish preschool environment. Nordic Journal of Digital Literacy, 9(3), 145-169.

Retrieved

from https://www.idunn.no/dk/2015/03/_thats_how_much_i_can_do_childrens_agency_in digita

Plowman, L. (2016). Learning technology at home and preschool. In N. Rushby \& D.W. Surry (Eds.), The Wiley handbook of learning technology (pp. 96-112). Chichester, United Kingdom: Wiley. https://doi.org/10.1002/9781118736494.ch6

Plowman, L., McPake, J., \& Stephen, C. (2008). Just picking it up? Young children learning with technology at home. Cambridge Journal of Education, 38(3), 303-319. https://doi.org/10.1080/03057640802287564

Plowman, L., McPake, J., \& Stephen, C. (2010). The technologisation of childhood? Young children and technology in the home. Children \& Society, 24(1), 63-74. https://doi.org/10.1111/j.1099-0860.2008.00180.x

Plumb, M., \& Kautz, K. (2015). Barriers to the integration of information technology within early childhood education and care organisations: A review of the literature. Paper presented in Australasian Conference on Information Systems, 30 Nov-4 Dec 2015, Adeleide, Australia. Retreved from https://arxiv.org/abs/1606.00748

Pope, C., Ziebland, S., \& Mays, N. (2000). Qualitative research in health care: Analysing qualitative data. British Medical Journal, 320(7227), 114-116. https://doi.org/10.1136/bmj.320.7227.114

Potter, J., \& McDougall, J. (2017). Digital media, culture and education: Theorising third space literacies. London, United Kingdom: Palgrave McMillan. https//doi.ogr/10.1057/978-1-137-55315-7

Potter, W. J. (1996). An analysis of thinking and research about qualitative methods. Washington, DC: Psychology Press.

Prensky, M. (2001). Digital natives, digital immigrants, Part 1. On the Horizon, 9(5), 1-6. https://doi.org/10.1108/10748120110424816

Prosser, J. (2011). Visual methodology. In N. K. Denzin, \& Y. S. Lincoln (Eds.), The Sage handbook of qualitative research (pp. 479-496). Thousand Oaks, CA: Sage.

Punch, S. (2002). Research with children: The same or different from research with adults? Childhood, 9(3), 321-341. https://doi.org/10.1177/0907568202009003045

Puntambekar, S. (2013). Mixed methods for analyzing collaborative learning. In C. E Hmelo-Silver, C. A Chinn, \& A. M. O'Donnell (Eds.), The international handbook of collaborative learning (pp. 187-195). New York, NY: Routledge. 
Puroila, A.-M. (2002). The multiple faces of everyday life: Frame analysis of early childhood practices. European Early Childhood Education Research Journal, 10(2), 31-47. https://doi.org/10.1080/13502930285208941

Puroila, A.-M., \& Haho, A. (2017). Moral functioning: Navigating the messy landscape of values in Finnish preschools. Scandinavian Journal of Educational Research, 61(5), 540-554. dhttps://doi.org/10.1080/00313831.2016.1172499

Pyle, A., DeLuca, C., \& Danniels, E. (2017). A scoping review of research on play-based pedagogies in kindergarten education. Review of Education, 5(3), 311-351. https://doi.org/10.1002/rev3.3097

Rajala, A., Kumpulainen, K., Hilppö, J., Paananen, M., \& Lipponen, L. (2016). Connecting learning across school and out-of-school contexts. In O. Erstad, K. Kumpulainen, Å. Mäkitalo, K. C. Schrøder, P. Pruulmann-Vengerfeldt, \& T. Jóhannsdóttir (Eds.), Learning across contexts in the knowledge society (pp. 15-35). New Milford, CT: Sense. https://doi.org/10.1007/978-94-6300-414-5_2

Ramírez, E., Clemente, M., Recamán, A., Martín-Domínguez, J., \& Rodríguez, I. (2017). Planning and doing in professional teaching practice. A study with early childhood education teachers working with ICT (3-6 years). Early Childhood Education Journal, 45(5), 713-725. https://doi.org/10.1007/s10643-016-0806-x

Rantala, L. (2009). In search of third spaces in media education: An ethnographic study from fifth graders' media workshop. Pedagogy, Culture \& Society, 17(3), 385-399. https://doi.org/10.1080/14681360903194392

Ratner, C. (2002). Subjectivity and objectivity in qualitative methodology. Forum Qualitative Sozialforschung / Forum: Qualitative Social Research, 3(3). http://dx.doi.org/10.17169/fqs-3.3.829

Richardson, V. (1996). The role of attitudes and beliefs in learning to teach. In J. Sikula (Ed.), Handbook of research on teacher education (pp. 102-119). New York, NY: Mcmillan.

Richardson, V. (2003). Preservice teachers' beliefs. In J. Raths \& A.C. McAninch (Eds.), Teacher beliefs and classroom performance: The impact of teacher education (pp. 122). Charlotte, NC: Information Age Publishing.

Rideout, V. J., \& Katz, V. S. (2016). Opportunity for all: Technology and learning in lower income families: A report of the families and media project. New York: The Joan Ganz Cooney Center at Sesame Workshop. Retrieved from https://files.eric.ed.gov/fulltext/ED574416.pdf

Roberts-Holmes, G. (2014). Playful and creative ICT pedagogical framing: A nursery school case study. Early Child Development and Care, 184(1), 1-14. https://doi.org/10.1080/03004430.2013.772991

Ruckenstein, M. (2010). Toying with the world: Children, virtual pets and the value of mobility. Childhood, 17(4), 500-513. https://doi.org/10.1177/0907568209352812

Saaranen-Kauppinen, A., \& Puusniekka, A. (2006). KvaliMOTV-menetelmäopetuksen tietovaranto [Information reserve for teaching research methods]. Tampere, Finland: Yhteiskuntatieteellinen tietoarkisto. Retrieved from http://www.fsd.uta.fi/menetelmaopetus/ 
Salomaa, S. (2016). Mediakasvatustietoisuuden jäsentäminen varhaiskasvatuksessa [Structuring the media educational consciousness in early childhood education]. Journal of Early Childhood Education Research, 5(1), 136-161. Retrieved from http://jecer.org/wp-content/uploads/2016/06/Salomaa-issue5-1.pdf

Salomaa, S., \& Mertala, P. (in press). An Education-centred approach to digital media education. In I. Palaiologou \& C. Grey (Eds.), Digital pedagogy and early childhood: critical issues. Thousand Oaks, CA: Sage.

Salomaa, S.. Palsa, L., \& Malinen, V. (2017) Opettajaopiskelijat ja mediakasvatus [Teacher students and media education]. Julkaisuja 1. Kansallinen audiovisuaalinen instituutti. Retrieved from http://www.mediataitokoulu.fi/opettajaopiskelijat.pdf

Sandberg, A., Broström, S., Johansson, I., Frøkjær, T., Kieferle, C., Seifert, A., ... Laan, M. (2015). Children's perspective on learning: An international study in Denmark, Estonia, Germany and Sweden. Early Childhood Education Journal, 45(1), 71-81. https://doi.org/10.1007/s10643-015-0759-5

Sechrest, L., \& Sidani, S. (1995). Quantitative and qualitative methods: Is there an alternative? Evaluation and Program Planning, 18(1), 77-87. https://doi.org/10.1016/0149-7189(94)00051-X

Selwyn, N. (2003). "Doing IT for the kids": Re-examining children, computers and the "information society". Media, Culture \& Society, 25(3), 351-378. https://doi.org/10.1177/0163443703025003004

Selwyn, N., Boraschi, D., \& Özkula, S. M. (2009). Drawing digital pictures: An investigation of primary pupils' representations of ICT and schools. British Educational Research Journal, 35(6), 909-928. https://doi.org/10.1080/01411920902834282

Sheridan, S., Williams, P., Sandberg, A., \& Vuorinen, T. (2011). Preschool teaching in Sweden - A profession in change. Educational Research, 53(4), 415-437. https://doi.org/10.1080/00131881.2011.625153

Sintonen, S., Ohls, O., Kumpulainen, K., \& Lipponen, L. (2015). Mobiilioppiminen ja leikkivä lapsi [Mobile learning and playing child]. Playful Learning Center. University of Helsinki. Retrieved from https://helda.helsinki.fi/bitstream/handle/10138/154779/Mobiilioppiminen_ja_leikkiv a_lapsi.pdf

Slutsky, R., \& DeShetler, L. M. (2017). How technology is transforming the ways in which children play. Early Child Development and Care, 187(7), 1138-1146. https://doi.org/10.1080/03004430.2016.1157790

Smith, A. B. (1993). Early childhood educare: Seeking a theoretical framework in Vygotsky's work. International Journal of Early Years Education, 1(1), 47-62. https://doi.org/10.1080/0966976930010105

Sosiaali- ja terveysalan tutkimus ja kehittämiskeskus. (2005). Varhaiskasvatussuunnitelman perusteet [National Core Curriculum for Early Childhood Education]. Oppaita 56. Saarijärvi, Finland: Gummerus. Retrieved from https://www.julkari.fi/bitstream/handle/10024/77129/Varhaiskasvatussuunnitelmanper usteet.pdf?sequence 
Spyrou, S. (2011). The limits of children's voices: From authenticity to critical, reflexive representation. Childhood, $18(2), \quad 151-165$. https://doi.org/10.1177/0907568210387834

Streelasky, J. (2017). Tanzanian and Canadian childrens' valued school experiences: A cross case comparison. International Journal of Early Years Education, 25(3), 274-291. https://doi.org/10.1080/09669760.2017.1352491

Steyn, M., \& Moen, M. (2017). Drawing sadness: What are young children telling us? Early Child Development and Care. Advance online publication. https://doi.org/10.1080/03004430.2017.1301936

Stipek, D. J., Givvin, K. B., Salmon, J. M., \& MacGyvers, V. L. (2001). Teachers' beliefs and practices related to mathematics instruction. Teaching and Teacher Education, 17(2), 213-226. https://doi.org/10.1016/s0742-051x(00)00052-4

Stockall, N., \& Davis, S. (2011). Uncovering pre-service teacher beliefs about young children: A photographic elicitation methodology. Issues in Educational Research, 21(2), 192-209. Retrieved from https://eric.ed.gov/?id=EJ946017

Strauss, A., \& Corbin, J. (1998). Basics of qualitative research: Techniques and procedures for developing grounded theory (2nd ed.). Thousand Oaks, CA: Sage.

Suddaby, R. (2006). From the editors: What grounded theory is not. Academy of Management Journal, 49(4), 633-642. https://doi.org/10.5465/amj.2006.22083020

Suoninen, A. (2014). Lasten mediabarometri 2013: 0-8-vuotiaiden mediankäyttö ja sen muutokset vuodesta 2010 [Children's Media Barometer 2013: Media usage of 0-8 years of age and its changes since 2010]. Nuorisotutkimusverkosto/Nuorisotutkimusseura, verkkojulkaisuja, $75 . \quad$ Retrieved from http://www.nuorisotutkimusseura.fi/images/julkaisuja/lastenmediabarometri2013.pdf

Syvänen, A., Mäkiniemi, J. P., Syrjä, S., Heikkilä-Tammi, K., \& Viteli, J. (2016). When does the educational use of ICT become a source of technostress for Finnish teachers? Seminar.net, 12(2). Retrieved from https://journals.hioa.no/index.php/seminar/article/view/2281/2146

Szeto, E., Cheng, A. Y. N., \& Hong, J. C. (2016). Learning with social media: How do preservice teachers integrate YouTube and social media in teaching? The Asia-Pacific Education Researcher, 25(1), 35-44. https://doi.org/10.1007/s40299-015-0230-9

Tondeur, J., van Braak, J., Ertmer, P. A., \& Ottenbreit-Leftwich, A. (2017). Understanding the relationship between teachers' pedagogical beliefs and technology use in education: A systematic review of qualitative evidence. Educational Technology Research and Development, 65(3), 555-575. https://doi.org/10.1007/s11423-016-9481-2

Tondeur, J., van Braak, J., Sang, G., Voogt, J., Fisser, P., \& Ottenbreit-Leftwich, A. (2012). Preparing pre-service teachers to integrate technology in education: A synthesis of qualitative evidence. Computers \& Education, 59(1), 134-144. https://doi.org/0.1016/j.compedu.2011.10.009

Tuomi, J., \& Sarajärvi, A. (2012). Laadullinen tutkimus ja sisällönanalyysi [Qualitative research and content analysis] (5th ed.). Helsinki, Finland: Tammi. 
Twining, P., Heller, R. S., Nussbaum, M., \& Tsai, C. C. (2017). Some guidance on conducting and reporting qualitative studies. Computers \& Education, 106, A1-A9. https://doi.org/10.1016/j.compedu.2016.12.002

Uitto, M. (2011). Storied relationships: Students recall their teachers. Acta Universitatis Ouluensis. E, Scientiae Rerum Socialium 122. Oulu, Finlad: The University of Oulu. Retrieved from http://jultika.oulu.fi/files/isbn9789514296307.pdf

Ulker, R. (2012). Turkish children's drawing of nature in a certain way: Range of mountains in the back, the sun, couple of clouds, a river rising from the mountains. Educational Sciences: Theory and Practice, 12(4), 3173-3180. Retrieved from https://files.eric.ed.gov/fulltext/EJ1003009.pdf

Uusitalo, N. (2015). Hallinnan tekemiset: Mediakasvatuspolitiikan diskursiivinen tuottaminen [Doing governance: The discursive construction of media education policy]. Acta Universitatis Tamperensis 2111. Tampere, Finland: Tampere University Press, Retrieved from http://tampub.uta.fi/bitstream/handle/10024/98145/978-951-449956-2.pdf?sequence $=1$ \&isAllowed $=y$

Vaala, S., Ly, A., \& Levine, M. H. (2015). Getting a read on the app stores: A market scan and analysis of children's literacy apps. The Joan Ganz Cooney Center at Seasame Workshop. Retrieved from http://www.joanganzcooneycenter.org/wpcontent/uploads/2015/12/jgcc_gettingaread_exec.pdf

Van Laere, K., Peeters, J., \& Vandenbroeck, M. (2012). The Education and care divide: The role of the early childhood workforce in 15 European countries. European Journal of Education, 47(4), 527-541. https://doi.org/10.1111/ejed.12006

Van Laere, K., \& Vandenbroeck, M. (2018). The (in)convenience of care in preschool education: Examining staff views on educare. Early Years, 38(1), 4-18. https://doi.org/10.1080/09575146.2016.1252727

Van Leeuwen, T., \& Kress, G. (2006). Reading images: The grammar of visual design. New York, NY: Routledge.

Vangsnes, V., Økland, N. T. G., \& Krumsvik, R. (2012). Computer games in pre-school settings: Didactical challenges when commercial educational computer games are implemented in kindergartens. Computers \& Education, 58(4), 1138-1148. https://doi.org/10.1016/j.compedu.2011.12.018

Venninen, T., Leinonen, J., Lipponen, L., \& Ojala, M. (2014). Supporting children's participation in Finnish child care centers. Early Childhood Education Journal, 42(3), 211-218. https://doi.org/10.1007/s10643-013-0590-9

Vogt, F. (2002). A caring teacher: Explorations into primary school teachers' professional identity and ethic of care. Gender and Education, 14(3), 251-264. https://doi.org/10.1080/0954025022000010712

Wartella, E., Rideout, V., Lauricella, A. J., \& Connell, S. L. (2014). Parenting in the age of digital technology: A national survey (revised ed.). Center on Media and Human Development, School of Communication, Northwestern University. Retrieved from http://cmhd.northwestern.edu/wpcontent/uploads/2015/06/ParentingAgeDigitalTechnology.REVISED.FINAL_.2014.p $\mathrm{df}$ 
Wohlwend, K. E. (2017). Who gets to play? Access, popular media and participatory literacies. Early Years, 37(1), 62-76. https://doi.org/10.1080/09575146.2016.1219699

Zaranis, N., Oikonomidis, V., \& Linardakis, M. (2016). Factors affecting Greek kindergarten teachers to support or oppose ICT in education. In P. Anastassiades \& N. Zaranis (Eds.), Research on e-learning and ICT in education: Technological, pedagogical and instructional perspectives (pp. 203-216). New York, NY: Springer.

Zeichner, K. (2010). Rethinking the connections between campus courses and field experiences in college- and university-based teacher education. Journal of Teacher Education, 61(1-2), 89-99. https://doi.org/10.1177/0022487109347671

Yahya, R., \& Wood, E. A. (2017). Play as third space between home and school: Bridging cultural discourses. Journal of Early Childhood Research, 15(3), 305-322. https://doi.org/10.1177/1476718x15616833

Ylitapio-Mäntylä, O. (2009). Hoivaa, opettajuutta ja johtajuutta: Lastentarhanopettajan liikettä päiväkodissa [Nurturing, teaching and leadership: Early childhood teacher's movement in kindergarten]. In H. Ojala, T. Palmu, \& J. Saarinen (Eds.), Sukupuoli ja toimijuus koulutuksessa (pp. 189-209). Tampere, Finland: Vastapaino

Ylönen, S. (2012). Sallittua, salaista vai kiellettyä: Lasten medialeikkitilasta käydyt neuvottelut päiväkodissa [Allowed, secret or forbidden: Negotiations on children's media play in kindergarten]. In H. Strandell, L. Haikkola \& K. Kullman (Eds.), Lapsuuden muuttuvat tilat (pp. 85-115). Tampere, Finland: Vastapaino. 


\section{Original publications}

I Mertala, P. (2016). Fun and games: Finnish children's ideas for the use of digital media in preschool. Nordic Journal of Digital Literacy, 11(04), 202-226. https://doi.org/10.18261/issn.1891-943x-2016-04-01

II Mertala, P. (2017). Wonder children and victimizing parents: Preservice early childhood teachers' beliefs about children and technology at home. Early Child Development and Care. Advance online publication. https://doi.org/10.1080/03004430.2017.1324434

III Mertala, P. (2017). Digital technologies in early childhood education: A frame analysis of preservice teachers' perceptions. Early Child Development and Care. Advance online publication. https://doi.org/10.1080/03004430.2017.1372756

Reprinted with permission from the Scandinavian University Press (I) and Taylor \& Francis (II \& III).

Original publications are not included in the electronical version of the dissertation. 
164. Palmgren-Neuvonen, Laura (2016) Social interaction in the context of new literacies : pedagogical potentials of publishing-oriented learner-generated video production

165. Kestilä, Sointu (2016) Nuoreksi aikuiseksi epävakaassa kasvuympäristössä : nuorten kokemuksia arjessa selviytymisestä ja kasvuolosuhteista lastensuojelulapsena

166. Sulkakoski, Marjut (20/6) "Ihan vaan perusasiat pitää osata hyvin" : ammattikorkeakoulujen insinööriopiskelijoille lukion kokemusten pohjalta rakentunut matematiikkakuva

167. Jokela, Nina (2016) Saksan ääntäminen laulusarjassa Frauenliebe und Leben : tutkimuskohteena eksperttilaulajat

168. Oikarinen, Juho (2016) Technology-enhanced statistics learning experiment : a case study at upper secondary level

169. Knihtilä, Aila (2016) Eetoksena hyvyys ja kauneus : taiteilija ja musiikkikasvattaja Anna-Liisa Antila-Kaljusen toimintaelämäkerta

170. Suša, Rene (2016) Social cartographies of internationalization of higher education in Canada : a study of exceptionalist tendencies and articulations

17I. Lassila, Erkki T. (2017) Tensions in the relationships : exploring Japanese beginning teachers' stories

172. Rönkä, Anna Reetta (2017) Experiences of loneliness from childhood to young adulthood : study of the Northern Finland Birth Cohort 1986

173. Irjala, Marja (2017) Osallinen, syrjässä, marginaalissa, onnellinen? : tutkimus oppisopimuskoulutuksen erityisopiskelijoista Suomessa ja Saksassa

174. Kurki, Kristiina (2017) Young children's emotion and behaviour regulation in socio-emotionally challenging situations

175. Lujala, Elise (2018) Pohjoisen varhaiskasvatuksen puolesta : Oulun lastentarhanopettajakoulutus vuosina 1967-1995

176. Mertaniemi, Seija (20I8) Seitsemäsluokkalaisten kerrontaa kirjoittamisestaan opetusta eheyttävässä moniaineprojektissa

177. Pihkala, Suvi (2018) Touchable matters : reconfiguring sustainable change through participatory design, education, and everyday engagement for non-violence

Book orders: Granum: Virtual book store http://granum.uta.fi/granum/ 


\section{ACTA U N IVER S I TATIS O ULU ENS I S}

\section{HUMANIORA}

University Lecturer Santeri Palviainen

TECHNICA

Postdoctoral research fellow Sanna Taskila

MEDICA

$$
\text { Professor Olli Vuolteenaho }
$$

\section{SCIENTIAE RERUM SOCIALIUM}

University Lecturer Veli-Matti Ulvinen

\section{SCRIPTA ACADEMICA}

Planning Director Pertti Tikkanen

\section{OECONOMICA}

Professor Jari Juga

\section{ARCHITECTONICA}

University Lecturer Anu Soikkeli

EDITOR IN CHIEF

Professor Olli Vuolteenaho

\section{PUBLICATIONS EDITOR}

Publications Editor Kirsti Nurkkala

ISBN 978-952-62-I860-I (Paperback)

ISBN 978-952-62-I86I-8 (PDF)

ISSN 0355-323X (Print)

ISSN I796-2242 (Online) 